\title{
Archaeological Salvage Research at 41BX901, a Prehistoric Quarry in Bexar County, Texas
}

\author{
Daniel R. Potter \\ Center for Archaeological Research \\ C. K. Chandler \\ Center for Archaeological Research \\ Elizabeth Newcomb \\ Center for Archaeological Research
}

Follow this and additional works at: https://scholarworks.sfasu.edu/ita

Part of the American Material Culture Commons, Archaeological Anthropology Commons, Environmental Studies Commons, Other American Studies Commons, Other Arts and Humanities Commons, Other History of Art, Architecture, and Archaeology Commons, and the United States History Commons

Tell us how this article helped you.

This Article is brought to you for free and open access by the Center for Regional Heritage Research at SFA ScholarWorks. It has been accepted for inclusion in Index of Texas Archaeology: Open Access Gray Literature from the Lone Star State by an authorized editor of SFA ScholarWorks. For more information, please contact cdsscholarworks@sfasu.edu. 


\section{Archaeological Salvage Research at 41BX901, a Prehistoric Quarry in Bexar County, Texas}

\section{Creative Commons License}

\section{(c) (1) (8)}

This work is licensed under a Creative Commons Attribution-NonCommercial 4.0 International License 


\section{ARCHAEOLOGICAL SALVAGE RESEARCH AT 41 BX 901, A PREHISTORIC QUARRY IN BEXAR COUNTY, TEXAS}

Daniel R. Potter, C. K. Chandler and Elizabeth Newcomb

Center for Archaeological Research The University of Texas at San Antonio Archaeological Survey Report, No. 211 



\section{ARCHAEOLOGICAL SALVAGE RESEARCH AT 41 BX 901, A PREHISTORIC QUARRY IN BEXAR COUNTY, TEXAS}

Daniel R. Potter, C. K. Chandler and Elizabeth Newcomb

Texas Antiquities Committee Permit No. 950

Center for Archaeological Research

The University of Texas at San Antonio®

Archaeological Survey Report, No. 211 
The following information is provided in accordance with General Rules of Practice and Procedure, Chapter 41.11 (Investigative Reports), Texas Antiquities Committee:

1.Type of investigation: archaeological survey and testing of a school under construction;

2.Project name: New Middle School;

3.County: Bexar;

4.Principal investigator: Jack D. Eaton; Co-principal investigator: Daniel R. Potter;

5.Name and location of sponsoring agency: Northeast Independent School District, San Antonio, Texas;

6.Texas Antiquities Committee Permit No. 950;

7.Published by the Center for Archaeological Research, The University of Texas at San Antonio, San Antonio, Texas 78249-0658.

A list of publications offered by the Center for Archaeological Research can be obtained by sending $\$ 1.00$ to the Center for Archaeological Research, The University of Texas at San Antonio, San Antonio, Texas 78285-0658. 


\begin{abstract}
During the months of October and November, 1990, staff members and volunteers of the Center of Archaeological Research (CAR), The University of Texas at San Antonio (UTSA), conducted surface survey, mapping, subsurface testing and private collection research at $41 \mathrm{BX} 901$ and surrounding areas. 41 BX 901 is an extensive prehistoric chert stone quarry in northeastern Bexar county, Texas. The site had been selected for construction of a new middle school by the Northeast Independent School District (NEISD). Survey and testing research was performed in order to evaluate 41 BX 901 and to locate any additional archaeological remains which might be affected by school construction and operation. Extensive prehistoric archaeological remains were encountered at 41 BX 901 . Surface and subsurface testing at the site produced abundant lithic remains which indicate lithic procurement and the initial stages of tool fabrication took place here during prehistoric times. However, time-diagnostic artifacts were not recovered from 41 BX 901. Chronological placement of the site depends upon neighboring, more securely dated sites which, it is proposed in this report, had a functional relationship with 41 BX 901.
\end{abstract}

Although $41 \mathrm{BX} 901$ is one of the most impressive quarries yet documented in this region, the site has been largely destroyed by school construction. $41 \mathrm{BX} 905$, recorded as part of this project and likely a continuation of $41 \mathrm{BX} 901$ on neighboring property, is well preserved and will be proposed for national register status. No further archaeological research is recommended for $41 \mathrm{BX} 901$ due to the destruction of the site. Two neighboring sites, $41 \mathrm{BX} 903$ and $41 \mathrm{BX} 905$, merit national register status and protection from development and looting. 
TABLE OF CONTENTS

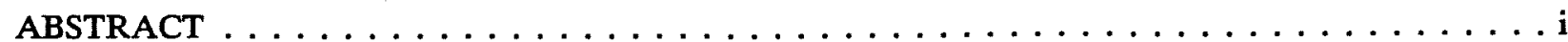

LIST OF FIGURES $\ldots \ldots \ldots \ldots \ldots \ldots \ldots \ldots \ldots \ldots \ldots \ldots \ldots \ldots \ldots \ldots$ ii

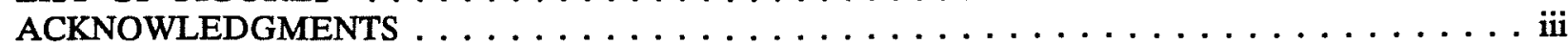

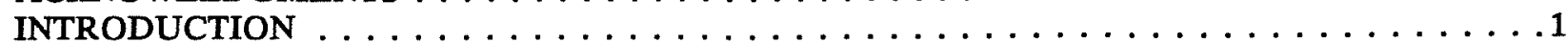

ENVIRONMENTAL BACKGROUND (Potter and Chandler) $\ldots \ldots \ldots \ldots \ldots \ldots$

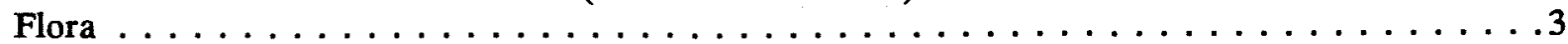

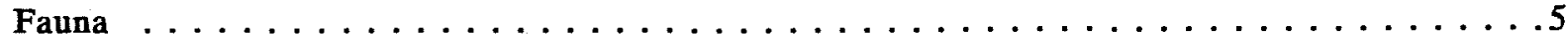

ARCHAEOLOGICAL BACKGROUND \& PREVIOUS RESEARCH $\ldots \ldots \ldots \ldots \ldots \ldots$

DESIGN FOR FIELD AND LABORATORY RESEARCH (Potter) $\ldots \ldots \ldots \ldots \ldots \ldots$

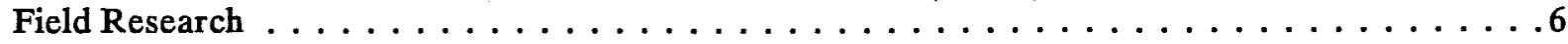

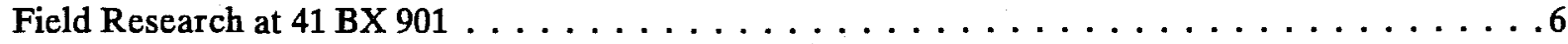

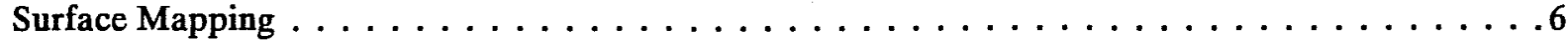

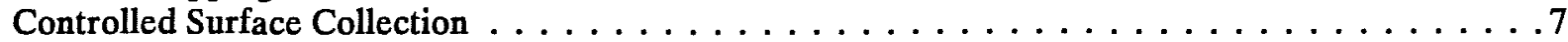

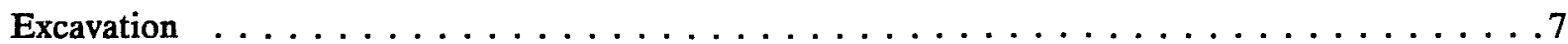

B. Archaeological Survey in the Vicinity of $41 \mathrm{BX} 901$ (Chandler) $\ldots \ldots \ldots \ldots \ldots \ldots$

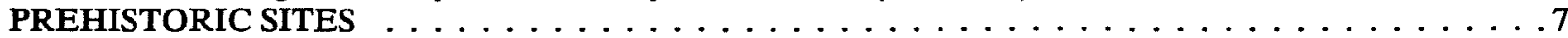

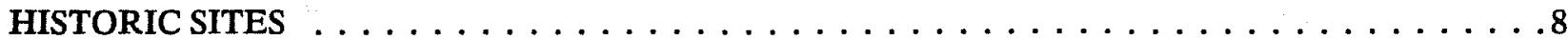

Research Design for Laboratory Analysis (Potter) $\ldots \ldots \ldots \ldots \ldots \ldots$

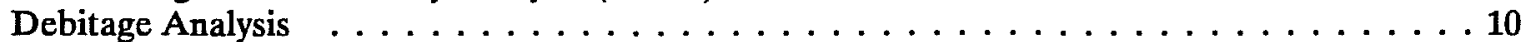

THE NEW SCHOOL QUARRY AS AN ARCHAEOLOGICAL RESOURCE:

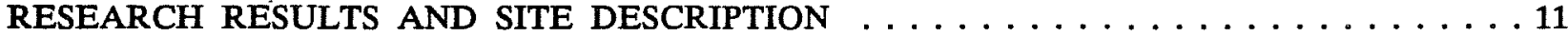

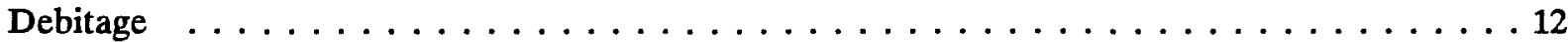

Debitage Analysis Results . . . . . . . . . . . . . . . . . . . . 19

Bifacial Artifacts . . . . . . . . . . . . . . . . . . . . . . . . . 19

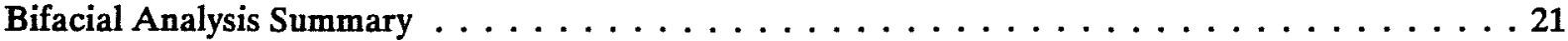

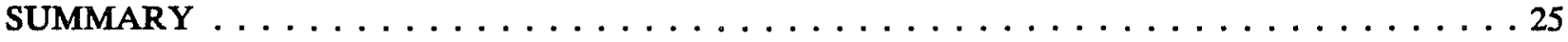

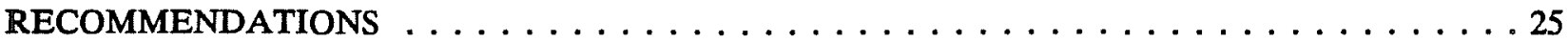

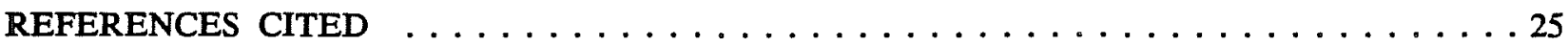

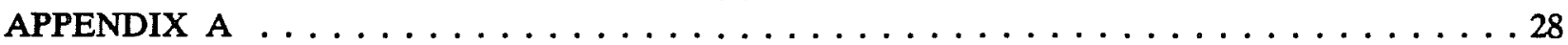

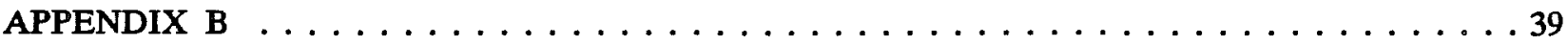

\section{LIST OF FIGURES}

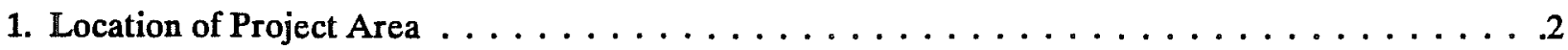

2. Mean Values for Debitage Variables . . . . . . . . . . . . . . . . . . . . . . . 13

3. Histogram: Flake Weight. . . . . . . . . . . . . . . . . . . . . . 14

4. Box-and-Whisker Graphs of Debitage Variables . . . . . . . . . . . . . . . . . . .15

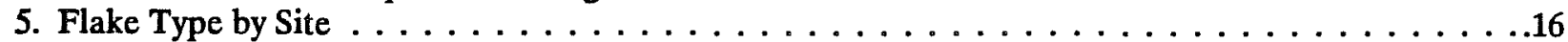

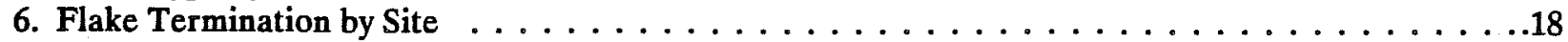

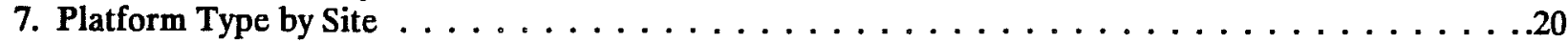

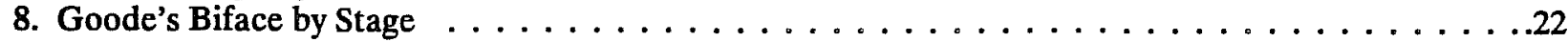

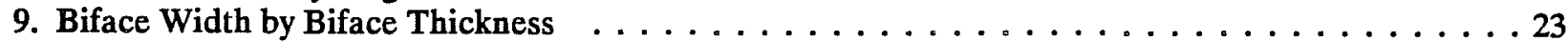

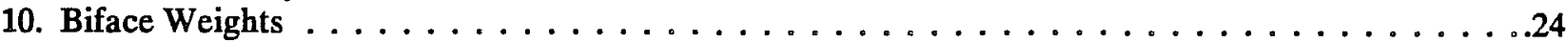




\section{ACKNOWLEDGMENTS}

The senior author wishes to thank the following people, without whom the project would not have materialized. Dr. Richard Middleton, Superintendent of Schools, and Mr. Fred Calhoun, Associate Superintendent of Operations, NEISD, initiated contact with the Center for Archaeological Research, The University of Texas at San Antonio (CAR-UTSA), and through their cooperation facilitated the rapid deployment of the CAR-UTSA research team. Mr. Mike Edwards and Mr. Darrell White of Bartlett Cocke, Jr. Construction Co., construction contractor, showed great patience and cooperation during the research team's work on site. Ms. Elizabeth Newcomb, a NEISD teacher and former CAR-UTSA staff member, first brought the site to my attention, served as a field archaeologist on the project, and is a co-author of this report. Mr. H. Ray Smith and Mr. C.K Chandler both served as field archaeologists on the project. Mr. Smith first discovered and recorded $41 \mathrm{BX}$ 901, and later worked on many fieldwork aspects of the project. Mr. C.K. Chandler, in addition to the survey work mentioned above, researched private collections and local

flora, as well as serving as co-author of this report. The above group made up the core of an excellent research team.

Several volunteers also worked on the project, and their participation facilitated additional fieldwork at $\mathbf{4 1}$ BX 901. These individuals include Ms. Candy Curry Smith, Mr. Richard Dobie, Mr. Kevin Gross, Ms. Barbara Meisner, Shirley and "Van" Van der Veer and Mr. Tom Kelly. At the UTSA laboratory, Ms. Cindy Tennis assisted in quantifying and coding debitage data. Additional volunteer support in the survey aspect of the project was provided by Ms. Virginia Chandler, Mr. Clint McKenzie, and Ms. Candy Curry Smith. To these volunteers the authors give thanks for a tremendous job. Their concern for the archaeological resources of San Antonio is recognized here and greatly appreciated.

Jack D. Eaton, acting director of the Center for Archaeological Research, supervised this project. The office staff at the Center for Archaeological Research, Ms.Brenda Stevens and Ms. Rachel Pullen, were instrumental in the preparation of this report. 



\section{INTRODUCTION}

In several ways this has been an unusual archaeological project. One of the unusual characteristics of the New School research has been the rapidity with which the project developed and went forward. This was due to the rather late discovery of 41 BX 901 relative to its swift destruction through school construction. The project has also been remarkable for the timely cooperation exhibited by a large number of people and agencies, all with very diverse interests, backgrounds, and goals.

Largely because of these diverse interests, the authors and project members envisaged a rather unconventional structure to the research plan at $41 \mathrm{BX} 901$ from the very outset of research. As with all research of this kind, the plan had first and foremost to satisfy the requirements of law regarding archaeological research and preservation undertaken in the state of Texas.

However, the project also had to address two additional goals. First, 41 BX 901 was seen as a promising educational resource for the Northeast Independent School District, and therefore our research has been aimed at beginning the process whereby some of the artifacts from the site might be developed into a teaching resource for the NEISD. A third goal was to understand how the $41 \mathrm{BX} 901$ quarry related to other prehistoric sites in the area. In order to approach this problem, archaeological research had to be expanded beyond the boundaries of the immediate project area in order to document surrounding archaeological sites. This third goal immediately produced unforseen benefits through the work of Mr. C.K. Chandler.

When first viewed by H. Ray Smith, Newcomb and Potter in September of 1990, 41 BX 901 was expressed as a very large quantity of tested chert nodules, cores, quarry blanks and chipping debris. This material was primarily visible in areas of the site which had been disturbed by construction activities. An estimated 70 to $80 \%$ of the site had already been altered in this fashion prior to the initiation of CAR-UTSA research. Destruction of the remaining portions of the site was continuing on a daily basis, necessitating immediate fielding of a research team.

This project was carried out under contract between the Northeast Independent School District and the University of Texas at San Antonio, Center for Archaeological Research. Fieldwork was done during October and November, 1990. Daniel R. Potter served as project director, assisted by C.K. Chandler and Elizabeth Newcomb, and many volunteers. Overall supervision was provided by Jack D. Eaton, CAR acting director. All work was done under Texas Antiquities Committee Permit No. 950.

\section{ENVIRONMENTAL BACKGROUND [Potter and Chandler]}

The Project area is located in northern Bexar county (Fig.1), and has been included in Taylor, Hailey and Richmond's (1966:119) Blacklands or Balcones Fault zone. The Blacklands zone is defined as a transitional geographic unit between the Rio Grande Plain to the south and the Edward's Plateau to the north. This north-south succession of geographic zones provides significant diversity in local environmental characteristics across the county, including flora and fauna, climate, and soils. In the immediate project study area, small seasonal streams and drainages are deeply incised into the landscape, providing for a local vertical relief of approximately 150 feet. (54.6 meters). 41 BX 901 is located on a gradual slope with an east-southeast exposure, and is somewhat protected both to the north and northwest by low hills. Floodplains are typically narrow in this area, and generally soil depth is minimal, although there can be pockets of deeper sediments in terrace situations. Upland soils are more uniformly thin, as was the case in the areas excavated during this project. In the immediate project area, thin Tarrant-series lithosols were underlain by limestone, which was clearly visible during fieldwork. In observing excavation by power machinery and blasting by explosives associated with construction activities, we noted that large numbers of high quality flint nodules were imbedded in limestone within one meter of the modern ground surface. While some nodules were only 30 to $40 \mathrm{~cm}$ in diameter, others were 60 to $80 \mathrm{~cm}$ in diameter and weighed well over $100 \mathrm{lbs}$. Glen Goode, an experienced replicator of prehistoric chert tools, has experimented with some of this material and notes that it is of very high quality and well-suited for tool manufacture. Undoubtedly, this geological characteristic of the local landscape is the salient reason for the location and nature of the archaeological remains here. 
This page has been

redacted because it

contains restricted

information. 
It is the senior author's opinion that this is an unusual locality both in terms of the quantity and quality of naturally occurring chert.

\section{FLORA}

The flora of this part of northern Bexar county also reflect its transitional nature. Located between Blair's Balconian and Tamaulipan Biotic Provinces (Blair 1950:102,112), the project area and its environs contains plant species common to both. The county's general vegetation pattern consists of a southern (Tamaulipan) zone dominated by thorny brush species, and a northern (Balconian) zone consisting of scrub forest species. A detailed listing of plants found locally has been compiled by C.K.Chandler as follows:

Agarita (Berberis trifiliolata)

Bluewood Condalia (Condalia hookeri

Buckeye (Ungnadia speciosa)

Cedar (Juniper: Juniperus ashei)

Elm (Ulmus crassifolia)

Ephedra (Mormon Tea: Ephedra antisyphilitica)

Evergreen Sumac (Rhus virens)

Grape Vine (Vitis mustangensis)

Greenbriar (Smilax Bona-nox)

False Willow (Baccharis neglecta)

Guayacan (Soap Bush:Porliera augustifolia)

Hackberry (Celtis laevigata)

Spiny Hackberry (Celtis pallida)

Kidneywood (Eysenhardtia texana)

Live Oak (Quercus virginiana)

Red Oak (Quercus texana)

Mesquite (Prosopis glandulosa)

Mountain Laurel (Sophora secundiflora)

Opuntia (Prickly Pear: (Opuntia lindheimeri)

Texas Persimmon (Diospyros texana)

Sotol (Dasylirion texanum)

Yucca (Spanish Bayonet, Spanish Dagger: Yucca treculeana)

Threadleaf Yucca (Yucca constricta)

Twisted-leaf Yucca (Yucca Yucca rupicola)

White Brush (Aloysia lingustrina)

Elbow Bush (Forestiera angustifolia)

Western Soapberry (Sapindus drummondii)

Wild Senna (Cassia lenheimeriana)

Dove Weed (Croton fructiculosus)

Canadian Wild Rye (Elumus canadensis)

Wild Poinsetta (Euphorbia cyathophora)

Cattail (Typhia latifolia)

Chandler has researched some of these plants further and makes the following observations concerning their traditional medicinal and/or nutritional qualities:

Agarita

Bluewood Condalia
This has a small edible berry and the roots are a source of dye (Tull 1987).

This also has small edible berries. The flower pollen is good Condalia bee food and the blue wood yields a dye (Cox and Leslie 1991). 
Cedar (Juniper)

Mormon Tea

Evergreen Sumac

Grape Vine

Greenbriar

Guayacan

Oak

Mountain Laurel

Opuntia

Sotol

Yucca
Both the berries and leaves are used, primarily as a urinary tract herb. The berries are most effective. The aromatic properties of all parts of the juniper plant have been used in many cultures against bad magic, plague and various negative influences. The rushed leaves were sometimes used as an incense and the hollow reed and cane cigarettes packed with charred leaves are known from southwestern archaeological excavations. The leaves were often carried in pouches or clothes as a means of protection or for use as medicine by some Indian groups. The leaves are also used in marinating and cooking wild meats (Moore 1982).

This is used as a domestic medicine in the treatment of syphilis and in the treatment of asthma and congestion. Relatives of this plant in China and India are a source of the ephedrine which in its synthetic state is known commercially as sudafed. The tea also has a pronounced diuretic effect and is still used as a basic remedy by indians and spanish speaking people of the southwest (Dwyer and Rattray 1986).

This has a small edible berry that is high in tannin. It is used as an astringent and by steeping in hot water to make tea (Vines 1960).

The leaves are edible and the sap of the vine is said to be used as a medicine to help in child birth (Leslie, personal communication).

The fresh new growth tips are edible (Leslie, personal communication).

The bark of the roots is still sold in Mexican markets as a soap for washing woolens. Extracts of the roots are used to treat rheumatism and venereal disease and they are also used as a medicine to produce sweat (Vines 1960).

All parts of the oak are useful. It is the basic astringent. Tea made from the bark is used as a wash for gum inflammation, a gargle for sore throats, as an intestinal tonic and for diarrhea. Tannin from the bark and twigs is a useful treatment for burns, abrasions, inflammation, and cuts, having a clotting, shrinking and antiseptic effect. The leaves can be chewed and applied to insect bites and stings. The bark can be chewed to lessen the pain of a minor toothache. The small balls sometimes called oak apples are much higher in tannin than the bark and are especially useful, fresh or dried, as an external wash and dressing (Moore 1982).

The red seeds and leaves of this plant are toxic. The seeds were used in hallucinogenic ceremonial activities (Cox and Leslie 1991; Vines 1960; Tull 1987).

The pads and fruit are edible and the fruit is also useful in making dye (Tull 1987; Flannery 1986).

The bulb of this plant was a staple food item for native populations in Texas and the southwest for centuries. The leaves were extensively used in making mats, sandals, baskets and rope. The long bloom stalk was used in quilting and for fuel (Tull 1987).

The roots of this plant are used as a sudsing agent in cosmetics and soap and as a home remedy for arthritic pain. It often has a strong laxative effect. The tea has some value for urethra and prostate inflammation. The leaves of the Yucca contain long thread-like fibers that can be extracted with the attached needle-like tip and woven into rough cloth (Vines 1960). 
Senna

Mesquite

Cattail
Poultices of the crushed roots were applied to sores by native peoples. Also boiled down and taken for fevers. Modern herbalists list wild Senna tea as a treatment for worms and excessive production of bile by the liver, as a breath sweetener, and as a diuretic. The plant is perhaps best known as a laxative (Dwyer and Rattray).

For centuries the mesquite has been a major source of food for many native american tribes in the arid southwest. The bean pods were available in the driest part of the year and they could be stored to last throughout the winter. The pods furnish protein, sugars, and carbohydrates, and are also rich in calcium, iron and other minerals. The green pods can be boiled to produce a nutritious syrup or ripe pods ground into meal (Tull 1987; Flannery 1968).

Euell Gibbons called cattails the supermarket of the swamps. Virtually every part of the plant has a use, from the root to the flowers. They can be harvested in any season. Starch is concentrated in the roots from late fall until early spring. The roots should not be eaten raw. The flowering stalk is edible while still green. The leaves and stems were woven into sandals, baskets, mats and used to cover shelters. Roots and leaves have been used for a variety of medicinal purposes and the floss has been used as a dressing for burns (Tull 1987).

\section{FAUNA}

To the senior author's knowledge, there are no comprehensive published studies of Bexar county faunal distribution. A detailed listing of past and present Bexar county fauna is given by Cristi Assad in a CAR publication concerning a major archaeological research project conducted by the CAR on the nearby Camp Bullis Military Reservation (Gerstle, Kelly and Assad 1978). Those interested in more information concerning Bexar county fauna are referred to Gerstle, Kelly and Assad (1978:26-29) and Blair's classic typology of Texas' biotic regions (1950).

\section{ARCHAEOLOGICAL BACKGROUND AND PREVIOUS RESEARCH}

With the number of recorded archaeological sites in Bexar county fast approaching 1000, it has long been obvious that the county is rich in archaeological resources. Legitimate archaeological research in Bexar county began in the 1930s but cannot be described as being particularly widespread or active until the 1960s with the onset of the Environmental Protection Act, and "Contract" or "Public Service" archaeological projects which arose to meet the aims of national environmental protection legislation.

Much of the research activity of the past 25 to 30 years in this regard has taken place in northern Bexar county, as the city of San Antonio has expanded to the north. A most important exception to this trend is the formidable archaeological research program associated with construction of the Applewhite Reservoir, located in southern Bexar county on the Medina River. This project, started by the CAR-UTSA (McGraw and Hindes 1987) and continued by Texas A\&M university by Thoms (1991), will add a wealth of new information concerning southern Bexar county archaeology as analysis and publication proceeds.

The northern part of Bexar county is more germane to the research reported here, and in particular, the Salado Creek drainage system has perhaps received more attention than any other in the county. The archaeology of Walker Ranch has been discussed in the survey research of Scurlock and Hudson (1979), Hudson, Lynn and Scurlock (1974), and Potter (1980), as well as the intensive excavation program at the important Panther Springs Creek site by Black and McGraw (1985). To the south in the Salado drainage the St. Mary's Hall site and the Granburg sites have received study but are not yet adequately published. In the northern reaches of the Salado drainage lie the Camp Bullis sites reported by Gerstle, Kelly and Assad (1978), Katz has recently published his investigations at 41 BX 300 (Katz et al. 1987). The senior author notes that one pattern revealed in these projects is that as one moves south into the area of larger and more 
permanent stream systems, archaeological sites tend to be deeper, more clearly stratified, and are probably larger, although this is difficult to prove due to the buried nature of many of these sites. As one moves to the north within the Salado drainage, archaeological sites show less depth, poorer stratification, and are probably on the average smaller than their more southerly counterparts. Shallow, extensive chert stone quarry sites such as 41 BX 901 are also much more typical of the northern extremity of Bexar county than central or southern areas of the county. Of particular relevance to this study from a comparative standpoint are a group of quarry sites defined in the camp Bullis survey (Gerstle, Kelly and Assad 1978) and two sites reported by Katz et al. (1987): 41 BX 299 and 41 BX 301. These recorded quarries closely resemble 41 BX 901 either in characteristics, or location, or both. It is appropriate to note here that $41 \mathrm{BX} 901$ is an outstanding example of this type of site, which is relatively common to northern Bexar county. Thomas $\mathrm{C}$. Kelly, who has direct experience with the Camp Bullis quarries, those in the vicinity of $41 \mathrm{BX} 300$, and other Bexar county quarry sites as well, has observed that $41 \mathrm{BX} 901$ is unique in terms of the quality and quantity of raw material available within the locality (Kelly, Personal Communication). We have already noted that Mr. Glen Goode, an archaeologist with the Texas Department of Highways and Public Transportation and an expert in the area of stone tool replication, has also observed the high quality of $41 \mathrm{BX} 901$ chert. Chert, essentially of hard cryptocrystalline quartz, resembles old world flints and has been a primary raw material for the making of stone tools and projectile points by prehistoric peoples.

\section{DESIGN FOR FIELD AND LABORATORY RESEARCH [Potter]}

\section{Field Research}

The project research was designed in response to two main goals. The first of these was to maximize data collection from $41 \mathrm{BX} 901$, a site which was being rapidly destroyed through school construction even before our investigations began. Second, it was decided that 41 BX 901 would be best understood as it related to other surrounding sites, which at that time were either completely unknown or inadequately known. This second goal had the advantage of researching sites which were not under immediate danger of destruction, as was 41 BX 901, and therefore could be accomplished without the time restrictions experienced in research at the quarry site. Unfortunately, work outside of the immediate construction site was not covered under the UTSA contract budget, and was accomplished only through volunteer labor on the part of C.K. Chandler and Daniel Potter. The two research programs will be discussed separately below. Work at 41 BX 901 was under the supervision of Potter, H. Ray Smith, and Newcomb, while the survey activities associated with the second research goal were handled by Chandler.

\section{FIELD RESEARCH AT 41 BX 901}

When fieldwork began in October of 1990, construction activities and associated land clearing had all but destroyed 41 BX 901 . Small areas of undisturbed landscape still existed along fencelines and around clumps of live oak which were slated for preservation. Archaeological research naturally focused upon these few undisturbed areas. Moreover, these undisturbed areas diminished in area and number as construction continued, and archaeological research changed or shifted to reflect this situation.

\section{Surface Mapping}

With the onset of fieldwork, a high priority was given to mapping technologically diagnostic archaeological materials on the surface of the site and collecting these before construction activities destroyed them. A standard four-screw optical transit and stadia were used to record these remains, generating a site map with piece-plotted artifacts as well as notable surface features such as fences, extant clumps of vegetation, collection areas, etc. H. Ray Smith was responsible for this aspect of the fieldwork, with the addition of volunteer efforts by Van and Shirley Van der Veer. 
Controlled Surface Collection

As additional areas of interest were discovered, various controlled surface collection techniques were employed to sample various parts of the site surface in addition to the transit-mapped collection described above. Fifteen contiguous 5-meter squares and one 1.5 meter diameter "dog-leash" collection area were used to investigate two distinctive areas of the site. The 5-meter squares were placed in an area of $41 \mathrm{BX}$ 901 which appeared to display a higher density of bifaces than other areas of the site, but was relatively low in debitage frequency. The 1.5 meter diameter dog-leash collection area was located in a high-density debitage scatter. Both of these surface-collection areas had already received an unknown amount of disturbance due to clearing activities and heavy machinery traffic. For this reason, cultural materials collected in each area were given only cursory inspection and were not included in the detailed analysis of archaeological materials from the site. They will be stored at the CAR-UTSA laboratory as part of the permanent site material inventory. It was decided that materials from excavated contexts would be more appropriate for detailed study.

Excavation

In the southeast corner of the NEISD property, the junction of two fencelines offered protection to a small portion of the site from construction and heavy machinery traffic. A single two meter excavation unit (collection unit "B") was placed here in order to investigate the nature of 41 BX 901 subsurface cultural remains. Two arbitrary $20 \mathrm{~cm}$. levels and one natural $15 \mathrm{~cm}$. level were completed, with excavation terminating at bedrock. Excavation revealed that soil development and subsurface remains were indeed shallow, with a maximum depth of 50 to 55 centimeters. Although the cultural deposit was not observed to be deep or stratified, it did produce an impressive quantity of quarry residues, indicating that $41 \mathrm{BX} 901 \mathrm{had}$ indeed been an important flint source in prehistoric times.

B.Archaeological Survey in the Vicinity of $41 \mathrm{BX} 901$ [Chandler]

The survey began in the 41 BX 901 location, with initial activity beginning by identifying adjacent property owners and obtaining their permission for archaeological survey. In some instances the owners knew of archaeological sites on their property and readily gave this information which was most helpful. The following discussion summarizes the results of the survey.

\section{PREHISTORIC SITES}

Six prehistoric sites were recorded on property either adjoining or nearby $41 \mathrm{BX} 901$. One of these is a large upland quarry site (41 BX 905) which is an extension of $41 \mathrm{BX} 901$, but separated by a property fence. This large quarry was recorded and numbered as separate from 41 BX 901 because of the near total destruction of the latter site, and that 41 BX 905 existed on separately owned property. Another site was found nearby. This was a large midden which had been extensively potholed, and is designated as $41 \mathrm{BX} 903$. A collection from this site was obtained for study and documentation. Results of this study will be incorporated in a later portion of this report. A $25 \mathrm{~cm}$ diameter test was excavated into the site by Chandler and Potter to a depth of $40 \mathrm{cms}$., where bedrock was encountered. The excavation utilized arbitrary $10 \mathrm{~cm}$ levels and all excavated soil was passed through a 1/4 inch screen, with all cultural material being collected. Another small subsurface test was excavated to a depth of $60 \mathrm{cms}$., in six arbitrary levels, with cultural materials encountered in all levels, indicating that the base of the cultural component had not encountered.

Another prehistoric midden (41 BX 909) was recorded lying at a lower elevation and a short distance to the south of $41 \mathrm{BX} 903$. This site is located on property being developed for residential construction. Some streets are already built and others were observed in various stages of development. 41 BX 909 has also been extensively potholed. A small amount of surface material from this site was collected and documented. 
In the immediate area of $41 \mathrm{BX} 909$, another large quarry site was recorded. This site, $41 \mathrm{BX} 907$, is some 30 to 50 feet below 41 BX 905 in elevation. Due to its lower elevation, and unlike the quarries at 41 BX 901 or $41 \mathrm{BX} 905$, this quarry area was not exposed on the surface until grade work for streets and drainages was in progress. The quarry chert material at this site appears to be of the same quality, color and consistency as that at $412 \mathrm{BX} 901$ and $41 \mathrm{BX} 905$.

Two other prehistoric sites recorded in the immediate area are $41 \mathrm{BX} 904$ and $41 \mathrm{BX} 906.41 \mathrm{BX} 904$ is on the edge of a small valley between 41 BX 903 and 41 BX 905. There are almost no lithic materials across the surface of this small valley, but an existing small pothole revealed 125 flakes (tool chipping debris) from looters backdirt picked up in a one meter diameter area. Immediately adjacent to this pothole a $25 \mathrm{~cm}$ test was excavated by Chandler and Potter to a depth of $40 \mathrm{cms}$., where bedrock was encountered. Excavation utilized arbitrary $10 \mathrm{~cm}$ levels and was passed through a $1 / 4$ inch screen. Chert flakes were found in all levels and one dart point was recovered in level two. The surface collected flakes and other excavated lithics are all part of the analysis for this project and will be described in more detail in another section of this report.

Site 41 BX 906 consists of a thin scatter of chert flakes on and just below the surface of a sloping area of the first terrace above Elm Waterhole Creek between Bulverde Road and Jones Maltsberger Road. This area is between $41 \mathrm{BX} 904$ and $41 \mathrm{BX} 909$. The soil is quite thin here and becomes thinner as the ground rises to the north toward $41 \mathrm{BX} 904$. In the area nearer the creek there are a number of small potholes. As one progresses toward higher elevations, limestone outcrops are encountered and surficial chert flakes become larger. No diagnostic artifacts were collected from this site by the survey crew and no collection by others has been identified.

A small area of about 10 acres north of Loop 1604 on Redland Road was surveyed, but no evidence of prehistoric occupation was discovered. This area had very recently been cleared of brush and the ground surface cleaned. Small pebbles were in profusion over all this area but no evidence of prehistoric activity was found.

Another area of about 40 acres bordering Loop 1604 on the south was surveyed with negative results. Much of this area had been extensively cultivated at some earlier time but is now largely grown up in small mesquite. The cultivated areas have been subjected to considerable erosion with a very noticeable movement of soil toward the lower elevations, partially burying perimeter fences. Outside the field area the ground rises sharply and becomes very rocky. The growth of cedar and other brush was too dense to make an adequate survey.

\section{HISTORIC SITES}

In addition to the six prehistoric sites recorded in the immediate area of $41 \mathrm{BX} 901$, six historic sites were recorded to the southeast. A small one-room cedar-log cabin (41 BX 914) with a front and back porch was recorded just east of Bulverde Road. While this structure is in poor condition, it is still standing, has a good roof, and is presently being used for storage. The one room has dimensions of 14 feet 4 inches by 15 feet 7 inches. There is a small enclosed room on the back porch. The cabin appears to have had a dirt floor, and possessed a limestone block fireplace at one end and one window at the opposite end. The fireplace and chimney are no longer standing, but many of the stones are scattered around the house.

A one-room house (41 BX 908), which burned in the 1950s, was recorded near the Missouri Pacific Railroad tracks east of Classen Road. This was a limestone-block house with dimensions of 16 feet 10 inches by 29 feet and has a fireplace at one end. It was constructed with caliche mud mortar and plastered inside and out with cement plaster. It had received additions on one side, and one end, prior to the time it burned. There are remnants of a number of collapsed outbuildings around the house and two unusually large underground cisterns. One cistern, on the northeast side of the house, is $11 \mathrm{feet}$ in diameter and about 31 feet deep. The second cistern, on the southwest side of the house, is 9 feet in diameter and about 31 feet deep. Both are lined with unmortared limestone. 
Another early stone house (41 BX 913) was recorded east of Classen Road and south of Loop 1604. The house is built of sawed caliche blocks in the settlement salt box style. It has one main room 17 feet 9 inches by 15 feet 8 inches and a smaller back room, and a front porch 7 feet 2 inches by 20 feet 3 inches. The house has a gable roof and a floored attic. This attic space served as a sleeping loft and had an exterior stair for access. The exterior stair is no longer present, and there is a straight wall ladder on the inside for attic access. The small back room has one end partitioned off where a toilet and shower facility is installed. This is not part of the original construction. The back room and front porch have shed-type roofs. All of the interior walls are plastered and painted. The entire structure originally had wood floors but these and the roof were extensively decayed at the time when the property changed hands in 1959 . The roof was replaced with standing "V" galvanized metal, and the ground floors replaced with poured cement. The house was built in 1863 and remained in possession of the descendants of the original owners until 1959 when it was sold. The purchaser found the house in need of total renovation and did make complete repairs. It is now in good condition and is being lived in.

In front of the $41 \mathrm{BX} 913$ structure is a rectangular cistern with dry-laid field limestone lining. It is 8 feet by 14 feet and generally remains full of water. The groundwater seeps through the limestone and frequently overflows the cistern, and the overflow goes to a clay tank a short distance down the hill. The cistern supplies water to the house for bathing and toilet use only. Water for drinking and cooking is brought in from the city water system.

Other historic sites recorded in the survey include two historic cemeteries and one isolated underground cistern. The two cemeteries are recorded as sites 41 BX 911 and 41 BX 912 . Neither is marked on city maps of San Antonio nor on the 7.5 foot longhorn Quadrangle Topographic map.

Site 41 BX 912 is a small, private cemetery between Jung Road and Classen Road, off Briarcrest Drive. It is fenced and well kept, probably by some family members. There are 14 headstones. The earliest one has the date January 17, 1895, with the inscription in German. The most recent head stone is dated 1946 with the same surname as the earliest stone, but in English.

Site 41 BX 911 is said by local residents to be a cemetery but there are no headstones. If they were ever there, they have been removed. This cemetery is in a residential area and is enclosed on three sides by back yard fences. The other side borders on an Elementary school ground and is enclosed with a chain-link fence. The developer of this residential area apparently had information that this area was a cemetery and did not build on it.

The isolated cistern is recorded as $41 \mathrm{BX} 910$. It is at the northeast corner of the intersection of Jung Road and the Missouri Pacific Railroad in NE San Antonio. It is in a very brushy overgrown area and is believed to have been associated with a railroad section house that may have been located there.

In addition to the sites recorded in this survey, recording activities have continued on a non-project basis as part of Chandler's archaeological stewardship activities. Six other sites have been identified in the northeast area of San Antonio and Bexar county, and in the Comal County area just north of Cibolo Creek. Two of these are historic family cemeteries in northeast Bexar County, one a historic family cemetery in Comal County, two are prehistoric sites in Comal county, and one is a prehistoric site in northeast San Antonio. All of these sites have been recorded and are currently logged at TARL in Austin and CAR-UTSA.

Artifact collections from 41 BX 842, 41 BX 903, 41 BX 908 and 41 BX 933 have been documented as part of this project. Documentation records are included in the files at CAR-UTSA and the Office of the State Archaeologist.

\section{RESEARCH DESIGN FOR LABORATORY ANALYSIS [Potter]}

It is commonly understood that a typical prehistoric quarry site witnessed only the initial stages of stone tool production, with final stages being undertaken elsewhere. The actual product of these initial stages of 
quarrying and tool fabrication is an artifact generally called a "quarry blank." Although there might be some minor deviations in form due to local factors, typical quarry blanks are comparatively crude, thick bifacial artifacts. Generally, manufacturing processes at quarries temporarily stop at the quarry blank stage, at which point the artifact is transported, exchanged, or otherwise removed from the quarry locality. For this reason, quarry sites such as 41 BX 901 are frequently quite low in finished, "diagnostic" artifacts. 41 BX 901, for example, did not produce a single artifact by which the site could be placed in a rough temporal context. By far the most important class of artifact recovered from quarry sites is debitage, and 41 BX 901 is no exception to this trend. The term debitage is used to refer to the flakes and chips of stone which are the by-products of chipped-stone manufacturing processes. Also present, albeit in fewer number, are bifaces which were discarded at some point during the manufacturing process. Either through production error or mishap, these artifacts were accidentally broken or otherwise precluded from later use, and were discarded. These are termed "manufacturing failures". In compliment with debitage, manufacturing failures are very informative about past production activities at prehistoric sites.

\section{Debitage Analysis}

During the course of this project, debitage has been a primary focus of analysis. One reason for this focus is due, as previously mentioned, to the fact that debitage is generally the most common class of artifact recovered from quarry sites. However, a second cause for this emphasis originates from an impression I have long held that archaeologists do not take full advantage of debitage analysis in their research, and there is a need to see what kinds of information a more intensive analysis might produce.

With this task in mind, samples of debitage were selected from several sites (including $41 \mathrm{BX} 901$ ) for the creation of a debitage data base. It is important to note that debitage (or, for that matter, any other recovered cultural material from this project) was not selected for this study in statistically probabilistic fashion. Rather, inclusion in the analysis was based upon recovery from selectively placed collection units. This caveat is offered because most statistical applications assume probabilistic methods have been used in selecting samples. By not employing such methods, we are not able to ascertain confidence in the collected samples undergoing analysis. Still, even with these serious reservations, it is proposed that statistical study of our samples is useful in providing insights into prehistoric lithic technology at the sites represented here.

Sites selected for the debitage study in addition to $41 \mathrm{BX} 901$ included $41 \mathrm{BX} 903,41 \mathrm{BX} 904,41 \mathrm{BX} 300$ and $41 \mathrm{ZV} 83$. Debitage from 41 BX 901 was extracted from Unit B, Level 1, a two-meter excavation placed in the northeast corner of the project area. Debitage from sites 41 BX 903 and 904 originate from $50 \mathrm{~cm}$. shovel tests at those sites excavated by Chandler and Potter as part of the survey program described previously. Debitage data from 41 BX 300 was taken from Katz's (1987:Appendix I) published study of that site, and includes utilized debitage only. Similarly, data from $41 \mathrm{ZV} \mathrm{83,} \mathrm{the} \mathrm{Mariposa} \mathrm{site} \mathrm{in} \mathrm{Zavalla} \mathrm{county,} \mathrm{Texas}$ (Montgomery 1978:43-48), also includes only utilized flake data. In these two cases, non-utilized debitage data were not published.

Regarding these last two sites, it is quite likely that significant differences will exist between utilized and non-utilized debitage from any given site. This contrast is due to the likelihood that selective preferences existed among the prehistoric users of these items for certain shapes, size ranges, etc. Thus, treating these populations as representative of a site involves substantial risk. However, due to the dearth of quantitative data on debitage and the need for comparison with our $41 \mathrm{BX} 901$ data, it was decided to go ahead and utilize the data from these sites, while keeping this potential bias in mind. One final source of debitage data comes from replication experiments conducted by Mr. Glen Goode, a staff archaeologist with the Texas Department of Highways and Transportation. Mr. Goode, at Potter's request, produced a biface and a worked core from unmodified chert nodules recovered from 41 BX 901 . Debitage from the biface-replication experiment was collected and bagged in three lots, each of which reflected a sequential cognitive (or "emic") manufacturing stage in Goode's tool making task. Each of these three stages was further divided into hard and soft-hammer debitage. These lots are currently being quantified and coded as a control population for subsequent 
analyses with archaeological materials at CAR-UTSA. All debitage in the current study (both archaeological and experimental) was analyzed using the following twelve variables:

flake length (LEN)

flake thickness (THK)

ratio of flake width to length (WL)

ratio of flake thickness to length (TL)

type of flake platform (PLAT)

two provenience variables (SITE1) and (SITE2) flake width (WID)

flake weight (WT)

ratio of flake thickness to width (TW)

type of flake termination (TERM)

type of flake (TYPE)

While most of these variables are self explanatory (LEN, WID, THK, WT, SITE1 AND SITE2), some may be unclear and in need of additional description. For example, it is important to note that the three ratio variables, WL, TW and TL, were intended as measures of whole-flake proportions, and can be viewed independent of the actual size and weight of debitage. TERM and PLAT are nominal morphological variables, dealing with the shape attributes of distal and proximal ends of flakes, respectively. Analysis was computer-assisted, utilizing spreadsheet, univariate and multivariate statistical, and graphic approaches.

\section{THE NEW SCHOOL QUARRY AS AN ARCHAEOLOGICAL RESOURCE: DESCRIPTION AND RECONSTRUCTION [Potter]}

\section{RECOVERED MATERIALS AND COMPOSITION OF 41 BX 901}

While recovery from the shovel tests at 41 BX 903 and 41 BX 904 were relatively minor, excavated material from the two by two meter Unit B at 41 BX 901 was truly impressive. From level one alone $(0-20 \mathrm{cms}$.), over 167 kilograms (nearly $370 \mathrm{lbs)}$ of chert were recovered, giving Unit B a chert weight density of nearly 42 kilograms per square meter. A preliminary breakdown of lithic weight by category provides the following figures:

$$
\begin{aligned}
& 76.73 \mathrm{Kg} .(46 \%) \\
& 48.89 \mathrm{Kg} .(29 \%) \\
& 27.53 \mathrm{Kg} .(16 \%) \\
& 13.17 \mathrm{Kg} \cdot(8 \%) \\
& 1.14 \mathrm{Kg} .(1 \%)
\end{aligned}
$$

cores/core fragments chips and chunks; incomplete debitage complete flakes tested cobbles unmodified cobbles

As noted previously, some areas of $41 \mathrm{BX} 901$ did not appear to have as high a density of lithic material as did Unit B. Thus, $42 \mathrm{Kg}$. per square meter may not be a representative density estimate for the site as a whole. In estimating density for the entire site, it was decided therefore to exclude material recovered from levels 2 and 3 , and to reduce the level 1 chert weight figure by 75\%. With an estimated area of 10 acres, and this very conservative density estimate, we can reasonably project that $41 \mathrm{BX} 901$ contains about 423 metric tons of chert. $41 \mathrm{BX} 905$, which is situated outside the project area, but is in fact a continuation of the $41 \mathrm{BX} 901$ quarry site, has a projected area of ca. 20 acres, yielding an estimated 847 metric tons. Thus the total quarry, including both 41 BX 901 and 41 BX 905 , contains an estimated 1,270 metric tons of chert, with worked chert making up $99 \%$ of the chert weight, as distributed in the categories listed above. This staggering figure, for just one of many quarry sites in northern Bexar county, gives some idea as to just how important this region was for prehistoric lithic procurement. 


\section{DEBITAGE}

As noted earlier, debitage data included in this study were produced by excavation units. For 41 BX 901 , a sample of 201 flakes were measured, coded and input into the computer. Approximately $80 \%$ of the level one material was sorted in order to produce this number of complete flakes.

Analysis of Variance (ANOVA) tests were run on all continuous variables, with the result that all but one variable (TW, or the ratio of thickness to width of flake) clearly indicated that significant differences existed among assemblages produced by sites in the study. Analysis suggests that the sites can be classified into two or possibly three groups. The first of these groups includes $41 \mathrm{BX} 901$ and $41 \mathrm{BX} 300$. Examination of Figure 2 reveals that mean values for flake length (LEN), width (WID), thickness (THK) and weight (WT) at these sites were similar to each other and much greater than those for all other sites in the study. The differences are actually greater than represented here, as the weight value (WT) of 65.53 grams was arbitrarily truncated for $41 \mathrm{BX} 901$, for the purpose of presentation. This value is clearly larger than at any other site in the study. In the case of $41 \mathrm{BX} 901$, this larger mean flake size is consistent with the site's apparently sole function as a quarry. While $41 \mathrm{BX} 300$ was also a quarry locality, this site differs from 41 BX 901 in that it also produced a wider range of materials and features, associated with archaic and late Prehistoric period burned rock middens and hearths. It can be inferred from these remains that a wider range of occupational activities took place at 41 BX 300 than at 41 BX 901.

It was observed during the analysis that mean values may be misleading when dealing with debitage. This is because sufficient "outlier" cases may exist in the data which effect the value of the mean, perhaps to a level where the mean becomes a skewed measure of the population as a whole. An example of this problem can be seen in a histogram of flake weight (Fig. 3) (by 5 gram intervals) for all sites combined. In this case, the vast majority of flakes fall well below (or to the left of) the mean value of 33.46, with over 240 flakes (over $47 \%$ of all flakes) falling between 0 and 5 grams in weight, the modal interval. A relatively small number of outliers are located above (to the right of) the mean value. It can be seen that one flake is located in the interval between 855 and 860 grams, another is found between 590 and 595 grams, and so on down the scale. Because of the nature of our data, such outliers will always be on the positive side of the scale, i.e. because flakes cannot have negative weights, we will never see negative outliers in the population, and all outliers are located on one side of the distribution. All of the size-related variables in the study reflect this "skewed" distribution to a greater or lesser extent, creating concern that mean values may be inappropriately large and therefore poor representatives of the population. In order to compensate for this possibility, it was decided to utilize the median values for variables as well as the mean. For example (Fig. 3), the median value for flake weight is 6.25 , which would place the median in the second "bar" to the right. Unlike the mean, the median is not affected by extreme outliers in a population, and may in some cases be a more representative statistic. Comparison of median values for this study is accomplished graphically by utilizing box plots, also known as "box and whisker" diagrams (Fig.4a,b,c). These plots show the median (vertical lines), quartile intervals (first and fourth, whiskers; second and third; boxes), outliers (points), and a rough indicator of significance (notches) of different medians (McGill, Tukey and Larsen 1978). The "notches" in these diagrams mark approximate $95 \%$ confidence intervals for the purpose of evaluating significance of differences between medians from the different sites. If the notches from different sites do not overlap at all, they are significantly different at the ca. 95\% confidence level (McGill, Tukey and Larsen:14). Compare the six sites (Fig. 4a, b, c) included in the study by three debitage variables (LEN, WID, THK). As was found during the comparison of means, it can be seen that significant differences exist between 41 BX 300 and 41 BX 901 on one hand, and the remaining four sites on the other. An additional argument can be made that $41 \mathrm{ZV} 83$ lies in a transitional position between the quarry sites and 41 BX 903, 41 BX 904 and Goode's replication assemblage, but this difference is not sufficiently demonstrated and might not hold true if we possessed a larger sample from that site. In addition, it will be recalled that our debitage from $41 \mathrm{ZV} 83$ is utilized, and may well be uncharacteristically large for debitage from that site. Nominal scale variables were also informative regarding differences between site assemblages within the study. Striking contrasts can be seen, particularly between sites $41 \mathrm{BX} 901$ and $41 \mathrm{BX} 903$, in terms of flake type (TYPE), platform type (PLAT) and flake termination type (TERM). Examination of Figure 5 displays these contrasts by graphing the distribution of flake type categories among sites in the present study. $41 \mathrm{BX} 901$ has the highest proportion of primary flakes $(5.47 \%)$ of any site, balanced proportions of secondary and tertiary flakes, and very few 
NEW SCHOOL PROJECT

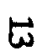

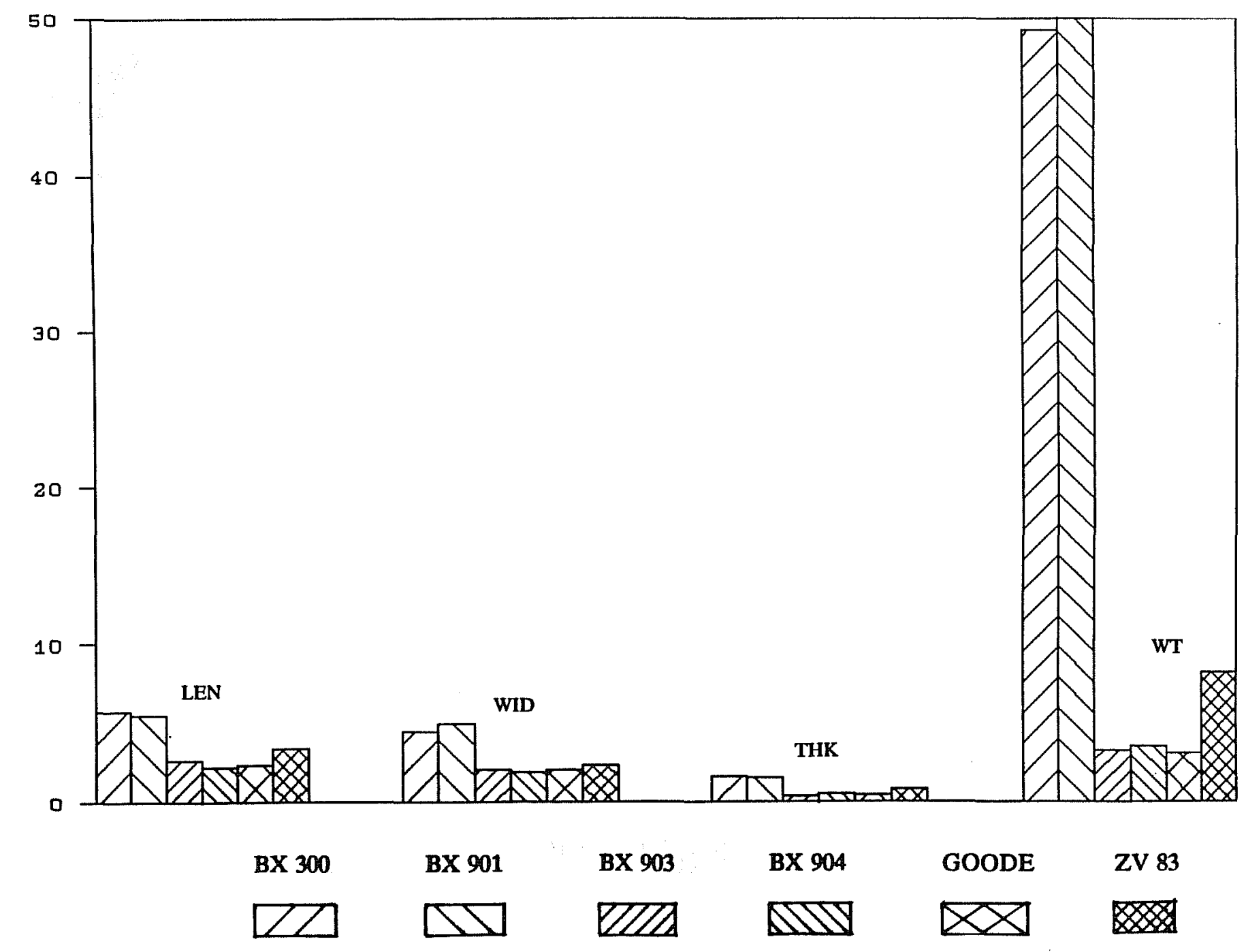

Figure 2. Mean Values for Debitage Variables. Variables are at six archaeological sites. The $Y$ axis indicates linear measurements ( LEN WID. THK) in centimeters, weioht (WT) in grams. 
NEW SCHOOL PROJECT

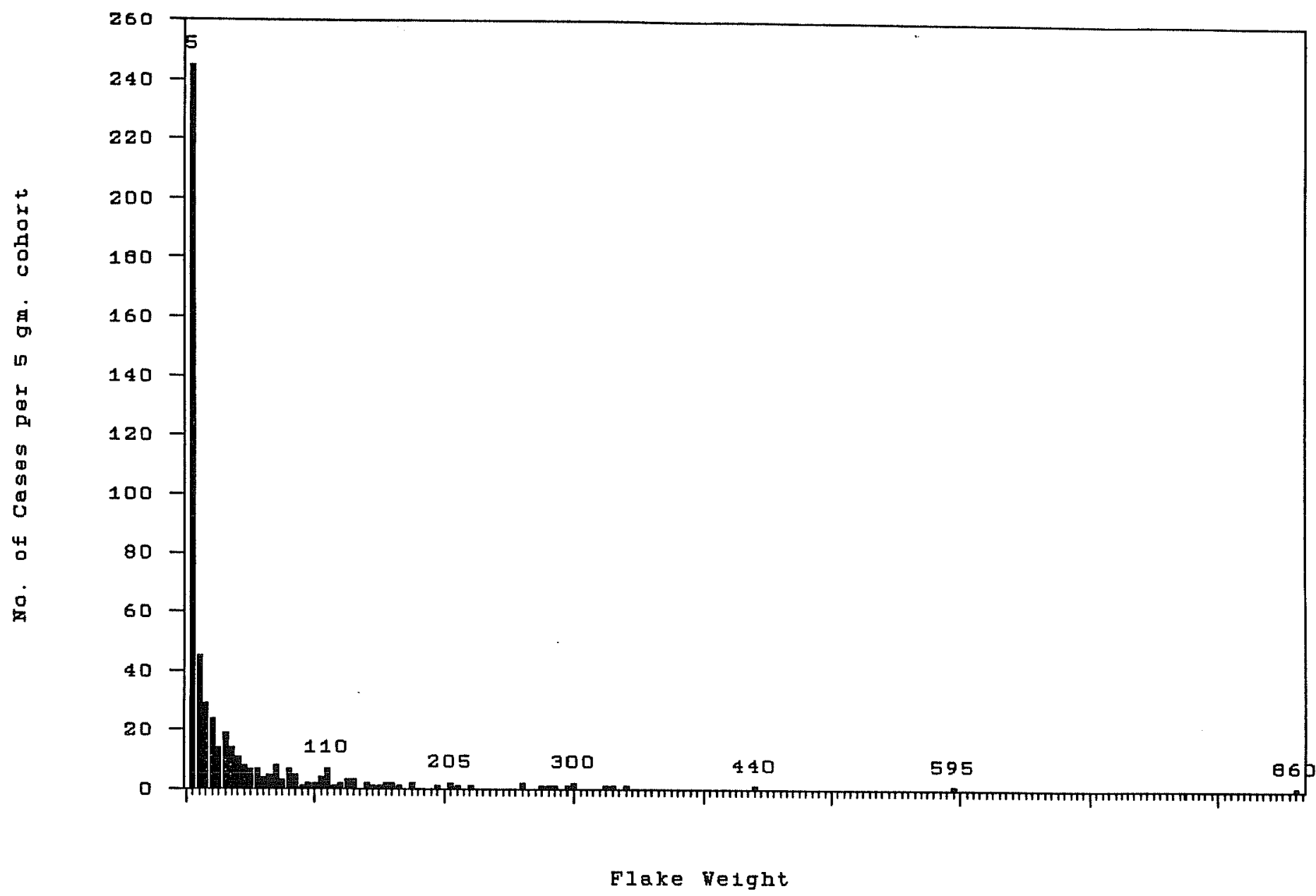

Figure 3. Histogram: Flake Weight. Flake weight (variable WT) for sample population from all sites. $\mathrm{X}$ axis equals weight by 5 gram intervals. $Y$ axis equals number of flakes falling into each 5 gram interval. 


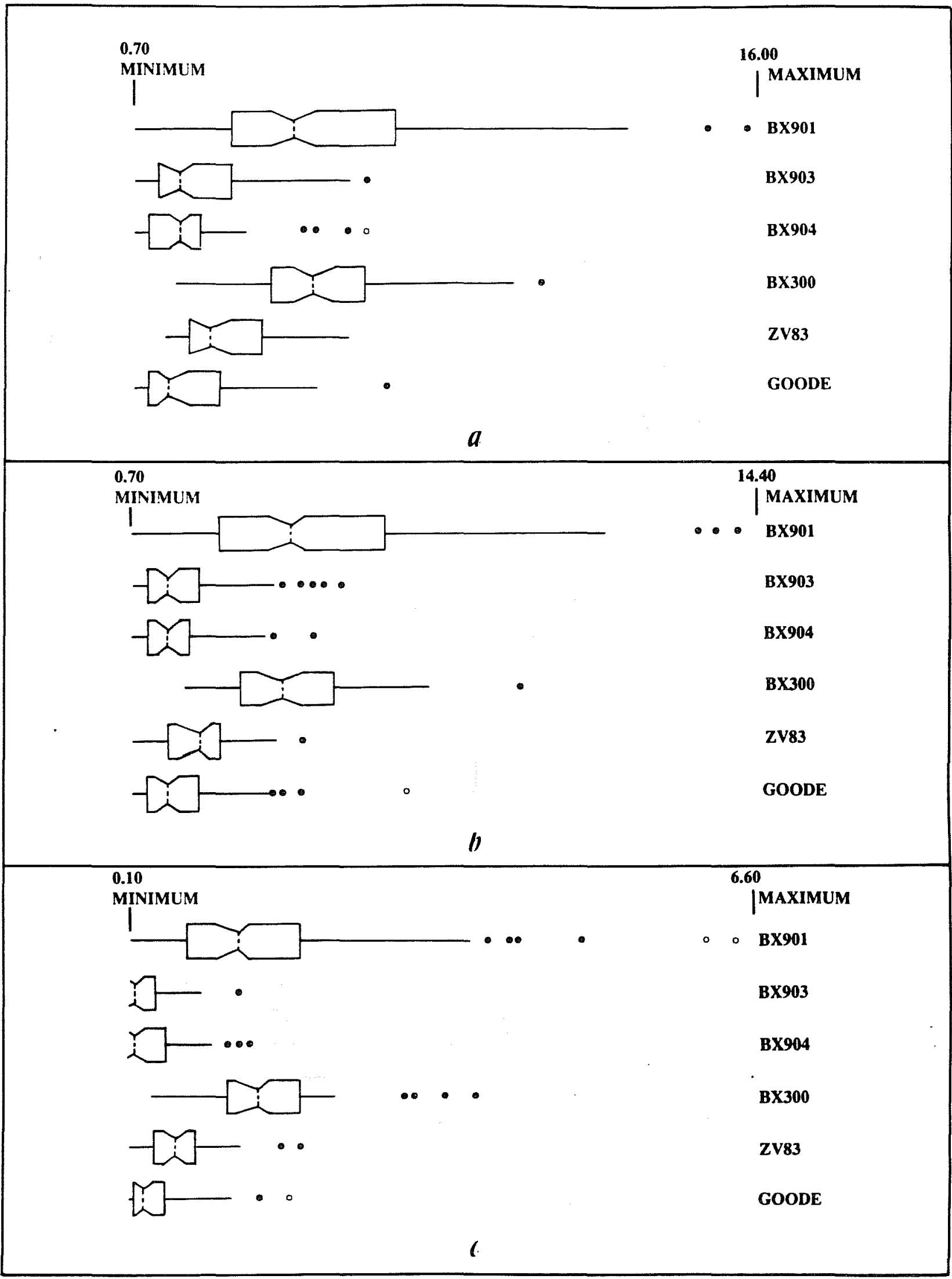

Figure 4. Bax-and-Whisker Graphs of Debitage Variables. Variables are for five archaeological sites and Goode's experimental assemblage. 4a) Flake Length (LEN); 4b) Flake Width (WID); 4c) Flake Thickness (THK). 
NEW SCHOOL PROJECT

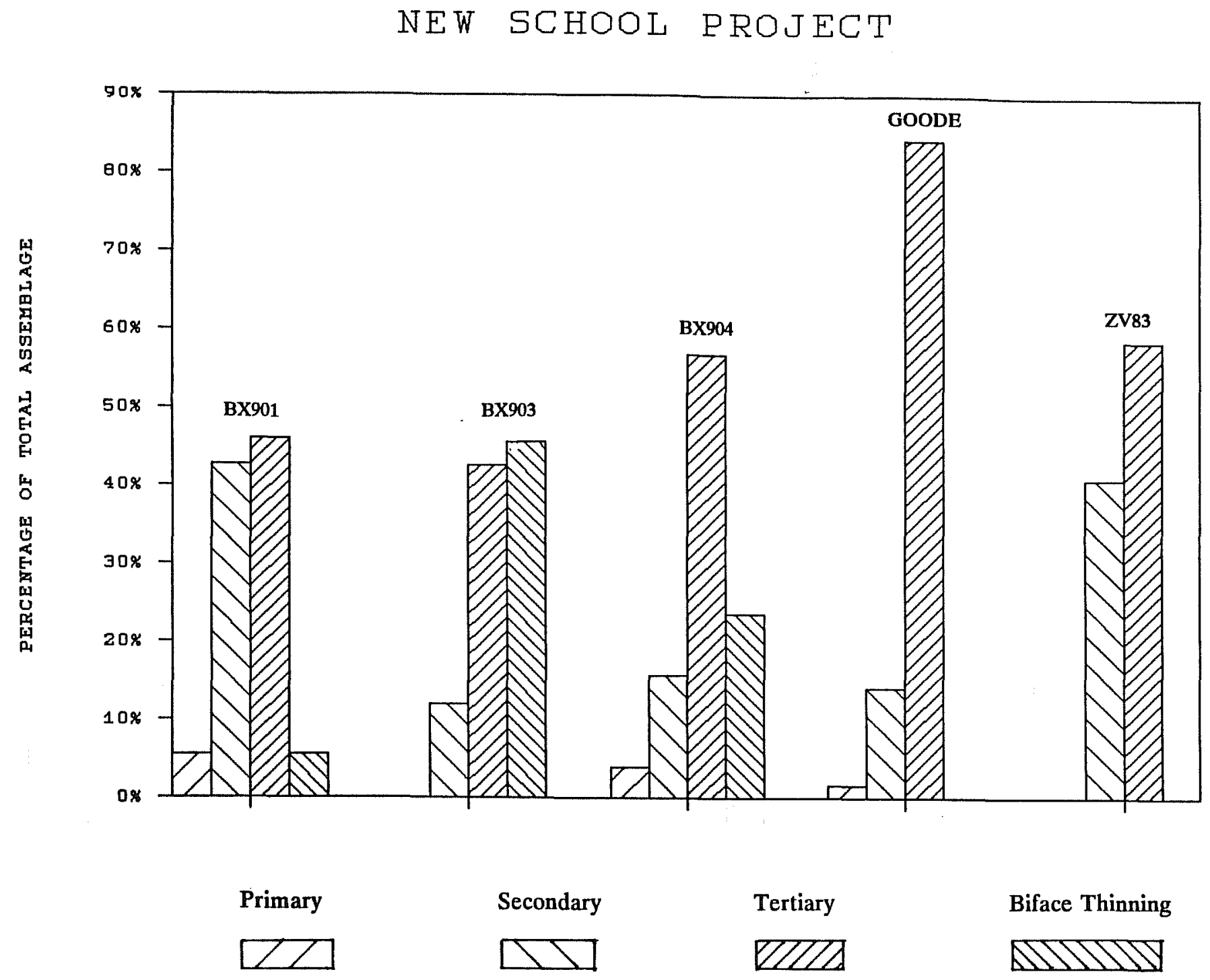

Figure 5. Flake Type by Site. Assemblage composition for debitage variable TYPE for four sites and Goode's experimental assemblage. Frequencies are given as percentage. 
tertiary biface thinning flakes. In contrast, $41 \mathrm{BX} 903$ possesses no primary flakes at all, only a few secondary flakes (11.88\% of the assemblage), and a very large proportion of tertiary flakes (ca. $88 \%$ of the assemblage), fully half of which (45\%) are biface thinning flakes. Site 41 BX 904 follows the general pattern of 41 BX 903 , although our sample from that site did possess 2 cortex flakes (under $4 \%$ of the assemblage), and also had relatively fewer tertiary biface thinning flakes (under 24\%) than did 41 BX 903 . Goode's assemblage consists of debitage from his "Stage I Hard Hammer" phase. It is very comparable to the latter two archaeological sites, with the exception that it contains no debitage which was categorized as "biface thinning." This will undoubtedly change as both soft-hammer flakes and debitage from his stages II and III are analyzed and coded.

Inspection of Figure 5 reveals obvious differences in assemblage composition among the sites in our study. As this discussion continues, it is hoped that these differences will be shown to be consistent with our initial conceptions of site function. As an objective check on observations noted above, a Chi-Square analysis was run on the distribution of flake types among these sites. This produced a statistic of 148.384, with 12 degrees of freedom. Using a probability level of .001, the critical score for Chi-Square [Xc) is 26.217 (Blalock 1972:569)], thus clearly indicating that the distribution of flake types differs significantly among sites in the study, and that the greatest differences exist between the two sites which are spatially the nearest neighbors.

Tabulation of flake termination types (TERM) also shows that differences exist among the sites in our study (Fig.6). Flake "termination" refers to the morphology of the flake at its distal margin, the end opposite the striking platform. The type of termination is essentially a measure of distal flake cross-section. Five types of termination were observed in the debitage sample, and were termed Feather, Straight, Bending, Hinge, and Plunging. Feathered terminations are those in which the dorsal and ventral sides of the flake gradually converge to create a thin, sharp edge. Straight terminations occur when the dorsal and ventral sides of a flake remain parallel or sub-parallel for most of the length of a flake, then converge rapidly near the distal end. Bending terminations curve moderately from ventral to distal faces of a flake. Hinge terminations are those which bend abruptly from ventral to distal sides of flakes. Plunging terminations can be thought of a "negative hinge terminations," in that they bend away from the dorsal face of a flake, frequently carrying away some piece of the biface or core being worked. Only two plunging fractures were recorded for the entire sample, and both of these occurred at $41 \mathrm{BX} 901$, the quarry site. Because of the very low incidence of plunging terminations, this category could not be included in statistical analysis, and has a minor impact on the study. Figure 6 displays the breakdown of termination types by site. While feathered terminations are the most prevalent type at each site, differences exist in degree of dominance, and again, the greatest contrast appears to exist between the neighboring sites of 41 BX 901 and 41 BX 903 . Under $48 \%$ of the 41 BX 901 debitage exhibits feathered terminations, while $41 \mathrm{BX} 903$ consists of just over $90 \%$ feathered terminations. Remaining sites fall between these two. Also important are the differences in frequency of straight, bending and hinge terminations between 41 BX 903 and all other sites in the study. Both straight and bending termination types comprise less than $1 \%$ of the $41 \mathrm{BX} 901$ sample, with hinge terminations being relatively scarce at $7.92 \%$. In contrast, hinge terminations at $41 \mathrm{BX} 901$ made up over $25 \%$ of the sample, and well over 10\% at 41 BX 904 and in Goode's STAGE I material which has been analyzed to date. Generally, these observations are consistent with site function. As a lithic procurement site, 41 BX 901 has a larger proportion of straight, bending and hinge terminations. Straight terminations are probably due to the large size and irregular shape of materials being worked at the quarry, and can be viewed as "successful" terminations from an "emic" perspective, as are "feathered" terminations. Hinge, step and plunging terminations, however, are a different matter. These patterns of flake fracture are commonly viewed as "unsuccessful", in that they are thought to be caused either by: a) flaws imbedded in the material being worked, or b) human errors in the application of force to the artifact being worked--or in other words, mistakes (Crabtree 1968, 1972; Hayden 1979:97-112,133-135; Purdy 1981:91). These mistakes largely deal with the amount and direction in which force is applied. All things being equal, the frequency of hinge, bending, and plunging terminations in an assemblage is negatively correlated with the amount of control exerted over the material being worked. In this case, the higher incidence of "unsuccessful" flakes at $41 \mathrm{BX} 901$ is expected, due to the likelihood that cobble-testing and initial-stage reduction are tasks which require less control and exactitude than the later stages of tool production. 
NEW SCHOOL PROJECT

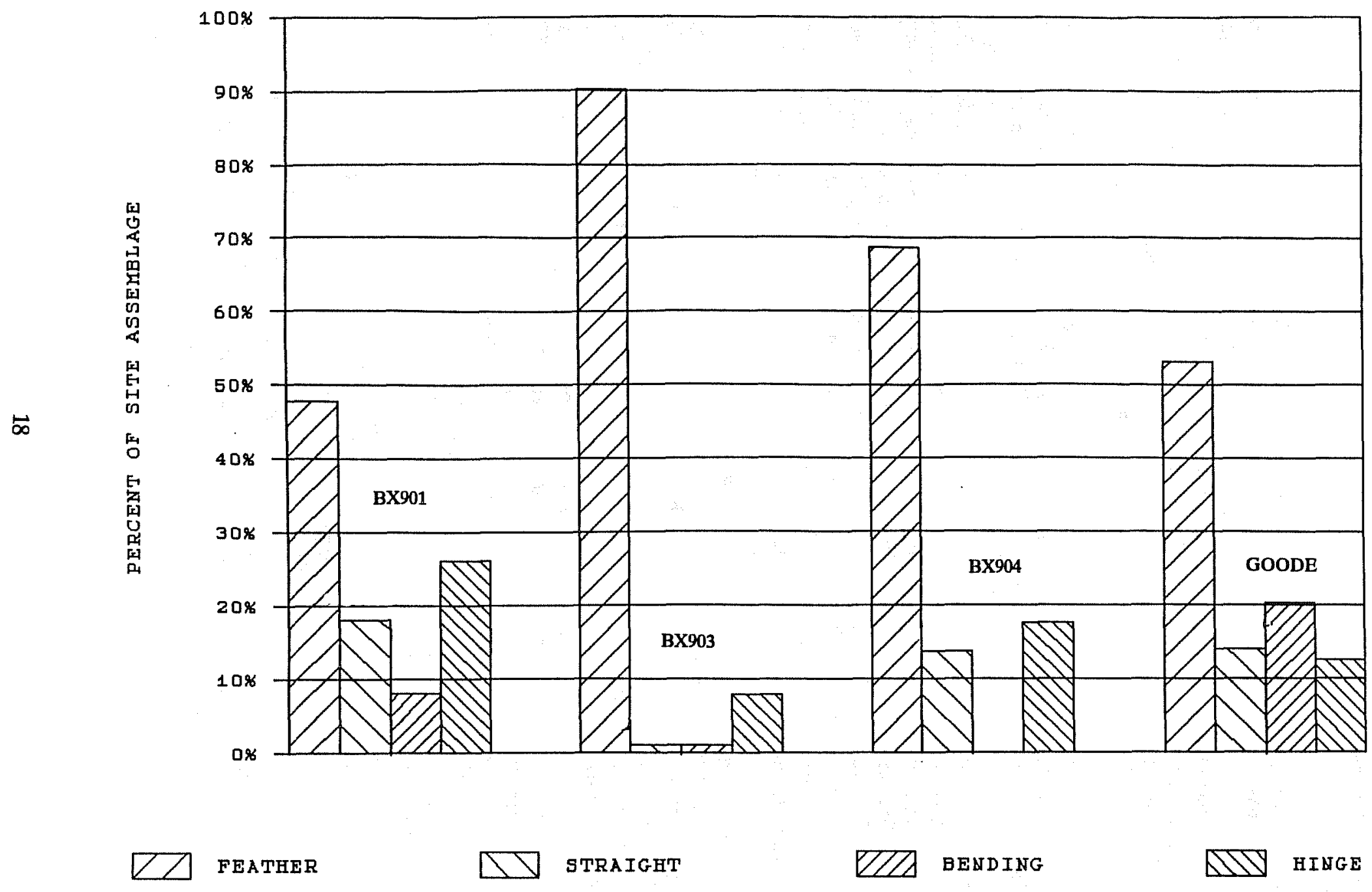

Figure 6. Flake Termination by Site. Assemblage composition for flake termination type (variable TERM) for four sites. Frequencies are given as percentage. 
As with the Flake Type variable (TYPE), Chi-Square analysis was run on termination (TERM) data. A test statistic of 74.294 was returned, with 9 degrees of freedom. At the .001 probability level, the critical value for Chi-Square (Xc) is 27.877). Again, this statistic in interpreted here as lending some objective support to the perception that significant differences exist in flake terminations among sites in the study.

As with the nominal-scale data concerning flake type and flake termination, striking platform type (the variable "PLAT") produced sharp contrasts among sites in the study. Striking platform variation was characterized by 4 categories: single facet, double facet, multiple (more than two) facet, and cortex facet. Figure 7 displays the distribution of platform types across site debitage assemblages in the study.

Again, perhaps the most striking contrast is seen between $41 \mathrm{BX} 901$ and $41 \mathrm{BX} 903$. It can be seen that 41 BX 901 is heavily weighted towards single facet platforms (over $59 \%$ of total). Generally, both single facet and cortex platforms are typical of quarrying and early-reduction assemblages. $41 \mathrm{BX} 901$ is consistent with this generality in that these two categories combined account for nearly $75 \%$ of the platforms observed. Double-facet and multiple-facet platforms, typical of later-stage reduction and tool maintenance, comprise the remaining ca. $25 \%$. Moving to 41 BX 903 , we see that multiple facet platforms alone make up over $70 \%$ of the observed platforms in that assemblage, with double facet platforms adding another ca. $8 \%$, for a total of over $78 \%$. As seen with the other variables, remaining site assemblages fall between these two, but are generally more similar to $41 \mathrm{BX} 903$. Thus the analysis of this variable underscores what we have learned from other variables in this study - that 41 BX 901 and 41 BX 903 have produced assemblages which appear to come from opposite ends of our sample spectrum. The former reflects the earliest stages of lithic production including cobble testing, core and quarry-blank production, while the latter indicates advanced stages of biface thinning and probably resharpening of functional tools.

\section{DEBITAGE ANALYSIS RESULTS}

Debitage data used in analysis is presented in Appendix A. The results from our debitage analysis have been such that, had we possessed no bifacial remains whatsoever from the sites involved in the study, our debitage samples alone would have been sufficient to indicate what kinds of lithic tasks were being undertaken there. The striking contrasts between debitage assemblages are given even more significance by the spatial proximity of $41 \mathrm{BX} 901$ and $41 \mathrm{BX} 903$, adding another element which must be considered. Namely, with these sites lying so close together, why are the lithic remains so dissimilar? One possible answer lies in the sampling problems that $I$ have discussed earlier in this report. While openly acknowledging these difficulties, I do not feel that the strong and consistent contrasts between the two sites can be adequately explained using this argument.

Another possible explanation is one involving the natural distribution of chert in the $41 \mathrm{BX} 901 / 903$ area, and differential access to that material. Our field investigations have revealed that $41 \mathrm{BX} 901$ occupies an area of extraordinary lithic abundance, even for a region well known for its quarry sites. 41 BX 903 does not exhibit the same natural abundance of chert. However, the site is located close enough to the $41 \mathrm{BX} 901 / 905$ quarry to have had ample access to the raw materials at those sites. $41 \mathrm{BX} 903$ is, after all, located less than 250 meters from either site, and it therefore seems unlikely that access would have been a problem.

I prefer to see these divergent assemblages as the result of spatially segregated steps in lithic tool-making trajectories. The striking differences between the quarry sites and 41 BX 903 and 41 BX 904 can be thought of as a kind of facies change between resource-procurement and resource-processing stages in local lithic tool-making trajectories. In essence, I interpret the debitage data as indicating that $41 \mathrm{BX} 901$ and $41 \mathrm{BX}$ 905 are parts of a specialized, limited-function procurement zone which fell within the resource catchments of nearby human settlements, including 41 BX 903 and 41 BX 904.

\section{BIFACIAL ARTIFACTS}

As mentioned previously in this report, finished bifacial artifacts are generally quite rare at quarry sites such as $41 \mathrm{BX} 901$. Instead, quarry blanks frequently make up the bulk of bifacial assemblages from these 
NEW SCHOOL PROJECT

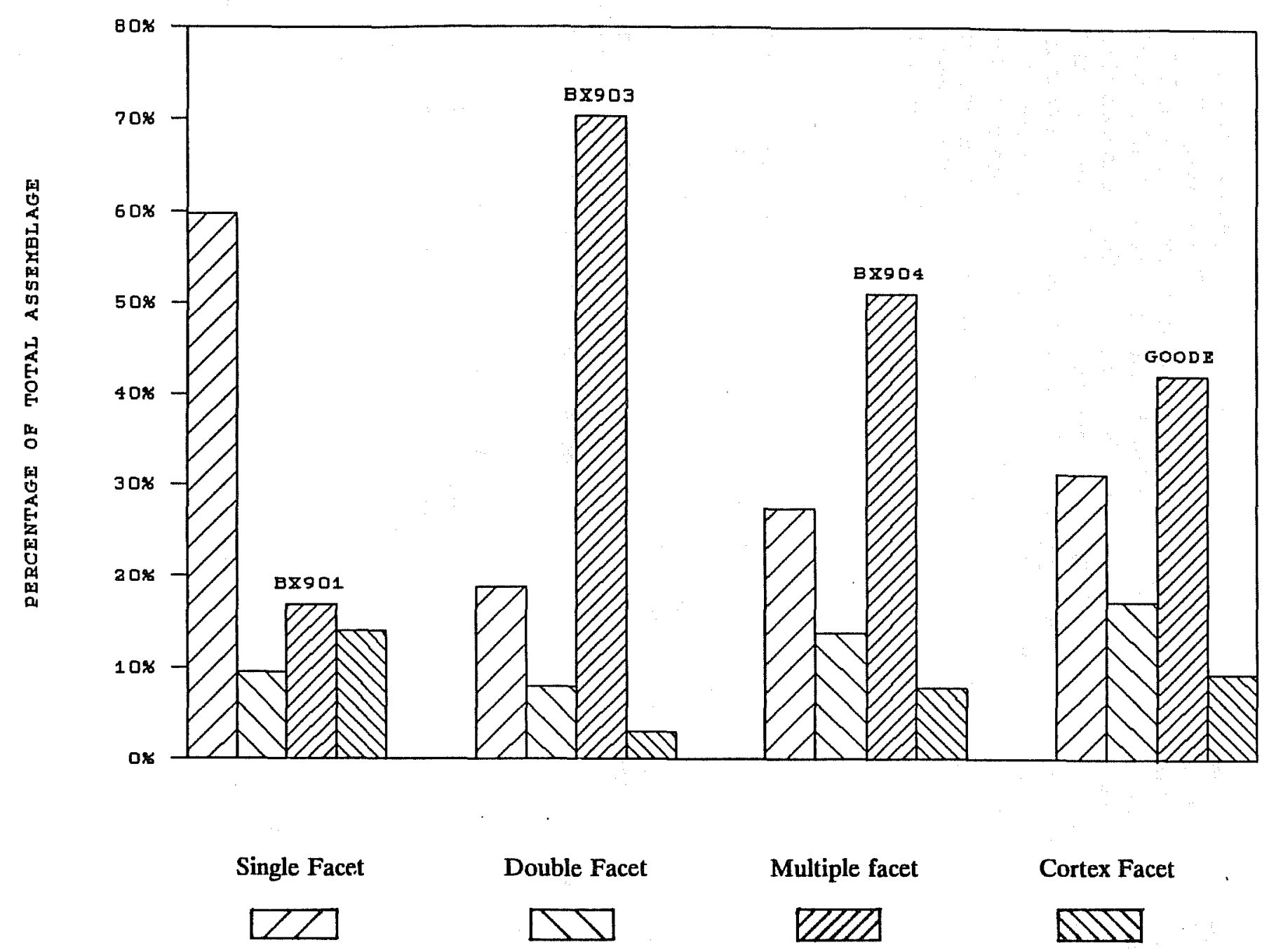

Figure 7. Platform Type by Site. Assemblage composition for flake striking platform (variable PLAT) for four sites. Frequencies are given as percentage. 
procurement sites. $41 \mathrm{BX} 901$ is no exception to this general trend. At $41 \mathrm{BX} 901$, the great majority of recovered quarry blanks and preforms came either from mapped surface collection of undisturbed areas of the site, or from unprovenienced "general surface" collection from altered or destroyed contexts due to construction activities. Unhappily, the latter context provided most of our recovered sample. Surprisingly, our excavation Unit B, which produced vast quantities of debitage and cores, provided no usable bifacial artifacts for analysis.

As previously described in this report, C.K. Chandler was able to document the private collections of landowners outside of the immediate project area, the most important of these coming from 41 BX 903. Chandler's work, supplemented by Potter's work, allowed comparitive analysis of biface assemblages from the two sites, in complement to the debitage analysis described previously. The biface study was oriented as a test of the results of the debitage analysis. Specifically, could it be demonstrated that the biface assemblage from 41 BX 901 represented early stages of reduction which could have ultimately led to the assemblage at $41 \mathrm{BX} 903$ ? In order to establish this possibility, the former would have to exhibit overall larger dimensions (e.g. length, width, thickness, etc.) than the majority of those in the 41 BX 903 assemblage. Analysis of Goode's experimental biface manufacturing data (Fig. 8) indicated that certain biface variables were more likely to show great change between manufacturing stages than would others. Biface weight (WT), for example, was the most dynamic variable with a reduction of over $84 \%$ between his stages I and III. Biface thickness (THK) diminished by more than $73 \%$ over the same interval. At the other end of the scale was biface length (LEN), the least changable of our recorded variables, with a reduction of only about $6 \%$ from stage I to stage III. This phenomenon of different degrees of change between stages for different variables is likely to be universal among biface-making trajectories, due to the physical mechanics of flintknapping, the nature of the raw material, and the generally uniform goals of flint knappers in this task. For these reasons, our working assumption was that our archaeological samples would directly parallel our experimental data.

Simple quantitative analysis of the bifacial assemblages from 41 BX 903 and 41 BX 901 indeed revealed striking contrasts between the two neighboring sites. In comparing the two assemblages, all diagnostic stemmed and notched artifacts from 41 BX 903 were excluded prior to analysis, as these were clearly smaller in all respects than the bifaces from $41 \mathrm{BX} 901$, and could have easily been produced on moderately-sized or small flakes. This left primarily the larger artifacts from the 41 BX 903 , which were classified as "thin bifaces", "small thin bifaces" and "preforms," for comparison with 41 BX 901 . Figure 9 provides one example of the contrasting nature of the two sites' biface assemblages, correlating two variables, biface width (WID) and biface thickness (THK). As can be seen, bifaces from 41 BX 901 show a marked tendency to be wider and thicker than those recovered from $41 \mathrm{BX} 903$. Ca. $75 \%$ of the bifaces from the former site are greater than $50 \mathrm{~mm}$. in width, while approximately $85 \%$ of the bifaces from the latter are less than $\mathbf{4 0} \mathrm{mm}$. in width, with a minor overlap zone between 40 and $50 \mathrm{~mm}$. A generally similar distribution can be seen in terms of biface thickness. The great majority of bifaces from the quarry site have thicknesses greater than $20 \mathrm{~mm}$., while an even larger proportion of bifaces from 41 BX 903 are thinner than $10 \mathrm{~mm}$., with a minor overlap in the assemblages from the two sites between 10 and $20 \mathrm{~mm}$.

As might be expected from the analysis of Goode's experimental biface data, the variable biface weight (WT) shows the greatest contrast between the two sites' assemblages (Fig. 10). While substantial variability within each assemblage is apparent, the general trend seen in Figure 10 is directly comparible to Goode's lithic reduction data for the same variable.

\section{Biface Analysis Summary}

As mentioned at the beginning of this section, analysis of the bifacial assemblage from two sites, $41 \mathrm{BX} 901$ and $41 \mathrm{BX} 903$, was undertaken in order to further illuminate differences discerned between these two sites as a result of debitage analysis. Analysis of Goode's biface reduction experiment also gave us a working model of how a number of variables would behave as a given biface advanced towards its final stages of production (Fig. 8). Exploratory statistical analysis of sample biface assemblages from 41 BX 901 and 41 BX 903 has been consistent with the results of debitage analysis. As demonstrated in the results of the debitage study, our rather small biface assemblages suggest that the two sites represent opposite ends of the 
NEW SCHOOL PROJECT

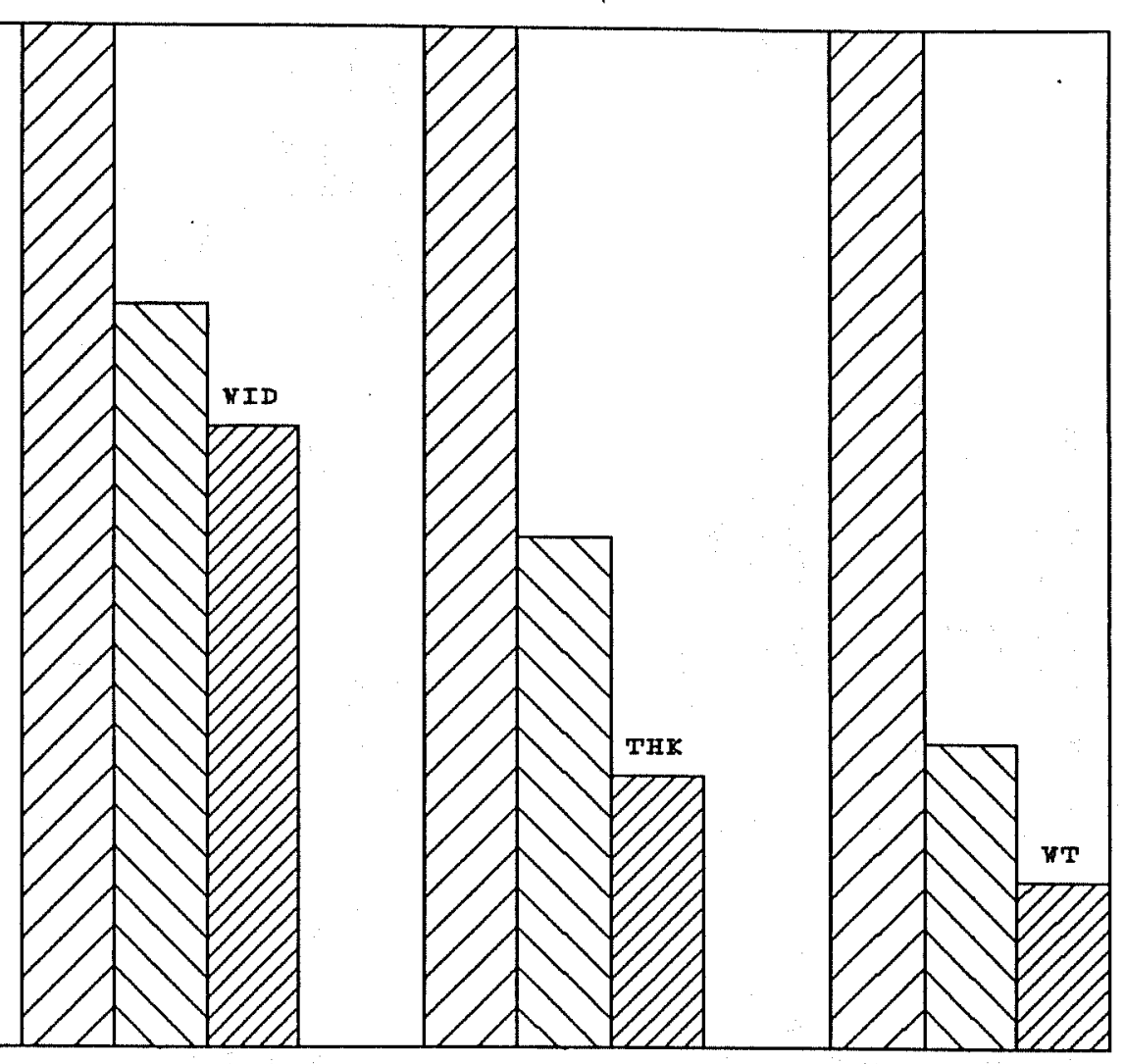

$\square$ stage i $\square \square$ stage it $\quad \square Z$ stage iti

Figure 8. Goode's Biface by Stage. Percentage change in four biface variables (length, width, thickness, weight) through three sequential manufacturing stages. Biface was experimentally produced by Mr. Glen Goode. 
NEW SCHOOL PROJECT

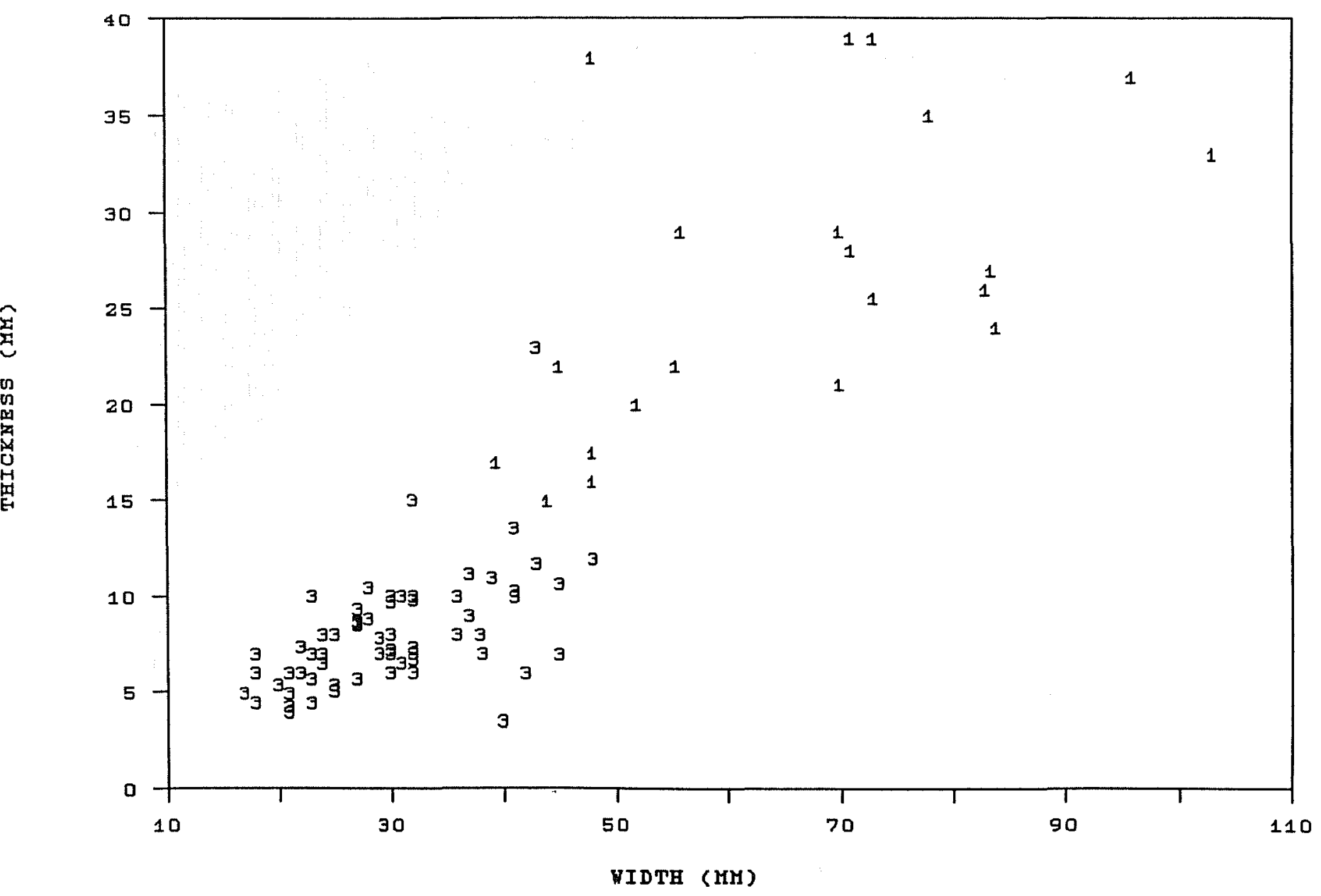

Figure 9. Biface Width by Biface Thickness. Graphic correlation of biface width (WID) and thickness (THK) for two sites: "1" signifies 41 BX 901, "3" signifies 41 BX 903 . Dimensions in millimeters. 
NEW SCHOOL PROJECT

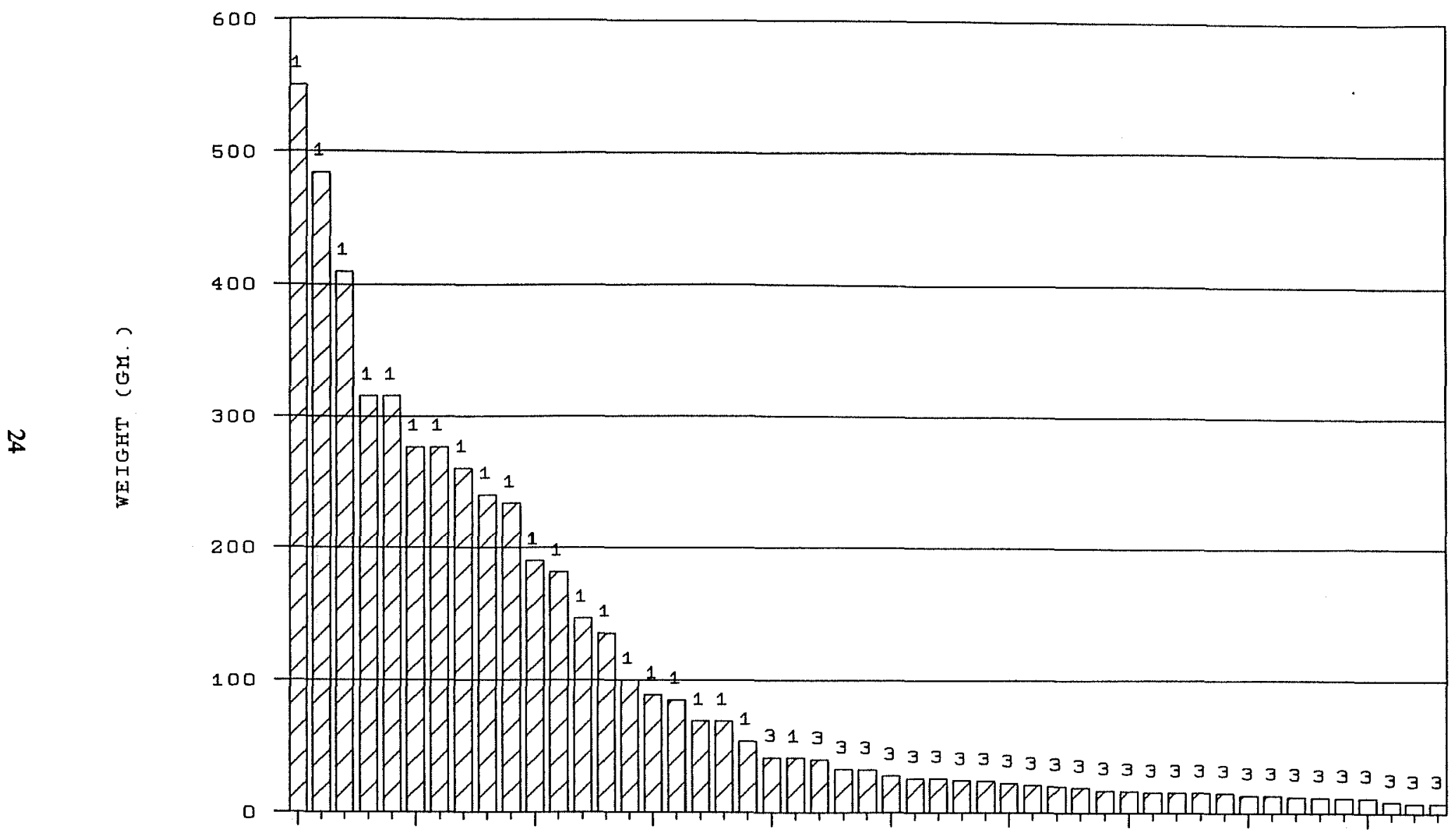

$1=41$ вX $901 \quad 3=41$ вX 903

Figure 10. Biface Weights. These data are thought to compare favorably with those from Goode's experimental biface for the same variable (Fig. 8). Weight in grams. 
lithic reduction sequence. We cannot prove that a direct relationship (quarry site-consumer site) existed between the two sites in prehistoric times, but their close spatial association certainly favors such an argument. Biface data used in analysis is presented in Appendix B.

\section{SUMMARY}

The present study has been, in a fashion, a novel approach to contracted archaeological research. It differs from many "contract" projects in that, although focused upon a portion of a single site in the advanced stages of destruction, it has been more concerned with relationships between sites within a small area of northwest San Antonio. Considered on its own merits, 41 BX 901 was an excellent example of a prehistoric lithic procurement site, or quarry. But even though BX 901 was a particularly rich example of a quarry, this type of site is quite common in south-central Texas, and is fairly well-documented in the archaeological literature.

What is different and important about the New School Project is that its scope of research was not limited by the physical restraints of the immediate construction site, or by the research constraints of a nessessarily fixed and finite research budget. Both of these barriers were circumvented by a perception of systemic relationships between sites in the area, and the willingness of many individuals to participate in the research project for no other reason than an abiding interest in and concern for San Antonio archaeology. As a result, much of this report centers not only on the 41 BX 901 quarry site but on surrounding sites which, as has been proposed, used the quarry and its resources. 41 BX 903 in particular has been proposed as a direct "consumer-site" of 41 BX 901 material, as demonstrated by its contrasting lithic assemblage. 41 BX 903 has been suggested as one of what were probably a number of surrounding "consumer-sites" that utilized the chert resources not only at $41 \mathrm{BX} 901$, but also $41 \mathrm{BX} 905$, and very probably other unrecorded chert outcrops in the area. A very similar relationship was proposed, in passing, for sites $41 \mathrm{BX} 301$ and $41 \mathrm{BX} 300$, located north of the present project area, by Katz et al. (1987:29-32). Their analysis, however, did not persue this observation and the idea remained speculative. The research here has been guided by the belief that archaeological sites, quarry or otherwise, gain in scientific value when they can be placed into a functional context with surrounding resources and with other sites. It should be kept in mind that these surrounding consumer populations were focusing on a wide range of other resources as well, but these are now largely archaeologically invisible due to their perishable nature, and the passage of time.

\section{RECOMMENDATIONS}

Unfortunately, no recommendations for future research or conservation measures can be offered for 41 BX 901. When first discovered, the site had already received substantial damage through school construction. By the close of fieldwork, the site was essentially destroyed. Happily, additional, undeveloped portions of the same quarry (designated 41 BX 905) exist on adjacent properties, and these now deserve our consideration. It is the senior authors opinion that this remaining portion of the quarry, recorded as $41 \mathrm{BX}$ 905 by Chandler as part of this project, deserves National Register Status, with the protection that this designation confers. As development continues and intensifies in San Antonio's northward expansion, many of the cultural resources in the northern part of the city will meet the same fate as did 41 BX 901 . One of the challenges to archaeological research and management in San Antonio is to prepare for this inevitable trend now, by protecting a variety of sites as San Antonio's archaeological posterity.

\section{REFERENCES CITED}

Blair, W. F.

1950 The Biotic Provinces of Texas. The Texas Journal of Science, Volume II, No. 1.

Blalock, H. M. Jr.

1972 Social Statistics. Second Edition. McGraw-Hill. New York, New York. 
Cox, P. W. and P. Leslie

1991 Texas Trees A Friendly Guide. Corona Publishing Company. San Antonio, Texas.

Cotterell, B. and J. Kamminga

1979 The Mechanics of Flaking. in: Lithic use-Wear Analysis. Brian Hayden, Ed. Academic

Press Studies in Archaeology series. New York.

Crabtree, D. E.

1968 Mesoamerican Polyhedral Cores and Prismatic Blades. American Antiquity 33:446-478.

1972 An Introduction to Flintworking. Occasional Papers of the Idaho State University Museum No. 28.

Dwyer, J. and D. Rattray

1986 Magic and Medicine of Plants. Reader's Digest Association.

Flannery, K. V.

1968 Archaeological Systems Theory and Early Mesoamerica. in: Anthropological Archaeology in the Americas. Betty J. Meggars, ed. The Anthropological Society of Washington.

Gerstle, A., T. C. Kelly and C. Assad

1978 The Fort Sam Houston Project: An Archaeological and Historical Assessment. Center for Archaeological Research, The University of Texas at San Antonio Archaeological Survey Report 40.

Katz, P. R.

1987 Archaeological Mitigation at 41 BX 300, Salado Creek Watershed, South-Central Texas. Center for Archaeological Research, The Unviersity of Texas at San Antonio, Archaeological Survey Report 130.

McGraw, A. J. and K. Hines

1987 Chipped Stone and Adobe: A Cultural Resources Assessment of the Proposed Applewhite Reservoir, Bexar County, Texas. Center for Archaeological Research, The University of Texasat San Antonio, Archaeological Survey Report 163.

Montgomery, J. L.

1978 The Mariposa Site: A Late Prehistoric Site on the Rio Grande Plain of Texas. Center for Archaeological Research, The University of Texas at San Antonio, Special Report 6.

Moore, $\mathbf{M}$.

1979 Medicinal Plants of the Mountain West. Museum of New Mexico Press. Sante Fe, New Mexico. 
Purdy, B. A.

1981 Florida's Prehistoric Stone Technology. University Presses of Florida. Gainsville, Florida.

Taylor, F.B., R.B. Hailey and D.L. Richmond

1966 Soil Survey of Bexar County, Texas, Series 1962, No. 12. United States Department of Agriculture Soil Conservation Service in cooperation with Texas Agricultural Experiment Station.

Thoms, A. V.

1981 Floodplain Environments and Archaeological Assemblages in the Lower Medina River Valley, South Texas. Paper presented at the 49th Annual Plains Conference, Lawrence, Kansas, November 1991.

Tull, D.

1960 A Practical Guide to Edible and Useful Plants. Texas Monthly Press. Austin, Texas.

Vines, R. A.

1960 Trees, Shrubs and Woody Vines of the Southwest. University of Texas Press. Austin, Texas. 
This appendix provides data on debitage from $41 \mathrm{BX} 901,41 \mathrm{BX} 903$, and other site assemblages used in this study.

\section{KEY TO CODED DEBITAGE DATA}

$\begin{array}{ll}\text { UNIQUE } & \text { Unique flake number } \\ \text { LEN } & \text { Maximum Length } \\ \text { WID } & \text { Maximum Width } \\ \text { THK } & \text { Maximum Thickness } \\ \text { WT } & \text { Weight } \\ \text { W/L } & \text { Ratio of Width to Length } \\ \text { T/W } & \text { Ration of Thickness to Width } \\ \text { T/L } & \text { Ratio of Thickness to Length } \\ & \\ \text { TERM } & \text { Type of Flake Termination } \\ & \\ & 1=\text { Feathered } \\ & 2=\text { Straight } \\ & 3=\text { Bending } \\ 4=\text { Hinge } \\ 5=\text { Plunging }\end{array}$

PLAT

Striking Platform Type

$1=$ Single Facet

2=Double Facet

3=Multiple Facet

$4=$ Cortex Facet

TYPE Flake Type

$$
\begin{aligned}
& \text { 1= Primary } \\
& \text { 2=Secondary } \\
& \text { 3=Secondary: Biface Thinning } \\
& \text { 4=Secondary: Core Trimming } \\
& \text { 5=Tertiary } \\
& \text { 6=Tertiary: Biface Thinning } \\
& \text { 7=Tertiary: Core Trimming } \\
& \text { 8=Tertiary: Biface Resharpening }
\end{aligned}
$$

STAGE

$$
\text { Cognitive Stage (Goode Debitage Only) }
$$

$$
\begin{aligned}
& \text { 1=Stage I: Hard Hammer } \\
& 2=\text { Stage I: Soft Hammer } \\
& \text { 3=Stage II: Hard Hammer } \\
& \text { 4=Stage II: Soft Hammer } \\
& 5=\text { Stage III: Hard Hammer } \\
& \text { 6=Stage III: Soft Hammer }
\end{aligned}
$$


$\begin{array}{llllll}\text { UNIQUE } & \text { LEN WID THK WT } & \text { W/L } & \text { T/W }\end{array}$

3

4

6

8

9

10

11

12

13

14

15

16

17

18

19

20

21

22

23

2

25

26

27

28

29

30

31

32

33

3

35

36

37

38

39

40

41

42

43

44

45

46

47

48

49

50

51

52

53

54

55

56

57
$1.5 \quad 1.4$

$1.7 \quad 1.4$

$\begin{array}{lll}1.2 & 1.4 & 0.4\end{array}$

$\begin{array}{lll}1.1 & 1.5 & 0.4\end{array}$

$\begin{array}{lll}1.5 & 1.1 & 0.3\end{array}$

$\begin{array}{lll}1.9 & 1.3 & 0.5\end{array}$

$\begin{array}{lll}1.3 & 2.6 & 0.4\end{array}$

$\begin{array}{lll}1.7 & 1.9 & 0.4\end{array}$

$\begin{array}{lll}2.2 & 1.8 & 0.4\end{array}$

$\begin{array}{lll}1.8 & 2.2 & 0.4\end{array}$

$\begin{array}{lll}2.5 & 2.4 & 0.4\end{array}$

$\begin{array}{lll}2.4 & 2.5 & 0.4\end{array}$

$\begin{array}{lll}1.8 & 2.3 & 0.5\end{array}$

$\begin{array}{lll}2.2 & 2.5 & 0.4 \\ 1.7 & 1.6 & 0.5\end{array}$

$\begin{array}{lll}1.7 & 1.6 & 0.5\end{array}$

$\begin{array}{lll}1.6 & 1.9 & 0.5\end{array}$

$\begin{array}{lll}1.3 & 2.4 & 0.5\end{array}$

$\begin{array}{lll}1.5 & 2.2 & 1.6\end{array}$

$\begin{array}{lll}2.2 & 1.4 & 0.6\end{array}$

$\begin{array}{lll}1.5 & 2.3 & 0.6\end{array}$

$\begin{array}{lll}2.3 & 1.7 & 0.6\end{array}$

$2.1 \quad 3.5$

$2.5 \quad 2.4$

$1.9 \quad 2.1$

$\begin{array}{ll}4 & 1.9\end{array}$

$2.2 \quad 2.3$

$\begin{array}{ll}4.6 & 2.5\end{array}$

$2 \quad 2.7$

$2.4 \quad 2$

$2.8 \quad 1.5$

22

$2.2 \quad 2.2$

3.7

2.4

4.8

35

2.6

2.9

3.3

2.1

2.5

3.5
2.4

2.9

3.9

3.5

3.6

3.9

2.4

3.2

3.4

$$
4.8
$$

$4.1 \quad 2.9$

$2.4 \quad 3.8$

$3 \quad 3.4$

$4 \quad 2.5$

$3.9 \quad 3.1$
0.3

0.7

0.6

0.3

0.5

0.3

0.5

0.6

0.7

0.5

0.5

0.6

0.5

0.5

0.4
0.5

0.7

0.7

0.6

0.5

1
0.8

0.8
0.9

0.8

0.5

0.7

3.2

3.8

0.6

0.8

0.9

0.8

0.7

0.7

1.1

1.2

1.2

0.8 $\begin{array}{lll}0.8 & 0.93 & 0.14 \\ 0.9 & 0.82 & 0.14\end{array}$

$0.9 \quad 1.17$

1.36

0.73

1.2

1.2

2
1.12

1.4

0.82

$\begin{array}{ll}1.5 & 1.22 \\ 1.5 & 0.96\end{array}$

0.29

0.27

$\begin{array}{ll}1.5 & 0.96 \\ 1.5 & 1.04\end{array}$

0.27

1.5
1.6

1.04

$\begin{array}{ll}1.6 & 1.28 \\ 1.6 & 1.14\end{array}$

$1.7 \quad 0.94$

1.8

0.94
1.19

21.85

$$
2.1
$$

1.47

2.2

0.64

2.4
2.6

1.53

0.74

2.7

1.67

0.96

2.8

1.11

0.48

3

3.1

1.05

3.1

0.54

1.35

0.83

3.3

0.54

3.3

3.4

4
4.4

0.57

4.6

4.6

4.6

4.7

4.7

4.8

4.8

4.9

4.9

4.9

6.1

6.2

6.7

6.9

6.9

7.8

8

8.1

8.3

9.4

9.5

9.5

9.6

1

0.54

0.36

0.54

1.35

0.93

0.88

1.52

1.04

0.63

0.96

0.86

0.97

0.86

0.89

0.97

1.71

0.94

1.12

0.5

0.71

1.58

1.13

0.63

0.79

0.38
0.15

0.21

0.22

0.18

0.17

0.16

0.22

0.16

0.31

0.26

0.21

0.73

0.43

0.26

0.35

0.09

0.29

0.29

0.16

0.22

0.12

0.19

0.3

0.47

0.25

0.23

0.29

0.21

0.19

0.22

0.26

0.2

0.26

0.21

0.16

0.38 $\begin{array}{rr}1.1 & 0.68\end{array}$

0.36 


\begin{tabular}{|c|c|c|c|c|c|c|c|c|c|c|c|}
\hline 59 & 3.3 & 2.3 & 1.3 & 10 & 0.7 & 0.57 & 0.394 & 2 & 1 & 2 & BX901 \\
\hline 60 & 3.1 & 3.6 & 1.1 & 10 & 1.16 & 0.31 & 0.355 & 1 & 2 & 2 & BX901 \\
\hline 61 & 3.7 & 3.7 & 0.8 & 10 & 1 & 0.22 & 0.216 & 1 & 3 & 5 & BX901 \\
\hline 62 & 4.7 & 2.7 & 1.1 & 11 & 0.57 & 0.41 & 0.234 & 4 & 1 & 5 & BX901 \\
\hline 63 & 4 & 3.1 & 0.7 & 11 & 0.78 & 0.23 & 0.175 & 3 & 1 & 5 & BX901 \\
\hline 64 & 2 & 4.6 & 1.1 & 11 & 2.3 & 0.24 & 0.55 & 2 & 1 & 4 & BX901 \\
\hline 65 & 4 & 3.9 & 0.7 & 12 & 0.98 & 0.18 & 0.175 & 4 & 3 & 6 & BX901 \\
\hline 66 & 3.1 & 3.2 & 1.5 & 12 & 1.03 & 0.47 & 0.484 & 4 & 3 & 5 & BX901 \\
\hline 67 & 5 & 2.7 & 0.7 & 13 & 0.54 & 0.26 & 0.14 & 1 & 4 & 2 & BX901 \\
\hline 68 & 4.1 & 4.4 & 1.1 & 13 & 1.07 & 0.25 & 0.268 & 4 & 1 & 5 & . $\quad$ BX901 \\
\hline 69 & 3.5 & 3 & 1 & 13 & 0.86 & 0.33 & 0.286 & 4 & 4 & 1 & BX901 \\
\hline 70 & 2.8 & 4.9 & 0.7 & 13 & 1.75 & 0.14 & 0.25 & 4 & 1 & 2 & BX901 \\
\hline 71 & 3.4 & 3.3 & 1.3 & 14 & 0.97 & 0.39 & 0.382 & 1 & 1 & 5 & BX901 \\
\hline 72 & 4.2 & 3.7 & 1 & 14 & 0.88 & 0.27 & 0.238 & 1 & 3 & 5 & BX901 \\
\hline 73 & 5 & 3.1 & 0.9 & 14 & 0.62 & 0.29 & 0.18 & 1 & 2 & 5 & BX901 \\
\hline 74 & 3.2 & 3.8 & 1.2 & 16 & 1.19 & 0.32 & 0.375 & 4 & 1 & 2 & BX901 \\
\hline 75 & 4 & 3.7 & 1.1 & 16 & 0.93 & 0.3 & 0.275 & 1 & 1 & 2 & BX901 \\
\hline 76 & 3.4 & 5.2 & 1.2 & 16 & 1.53 & 0.23 & 0.353 & 1 & 1 & 2 & BX901 \\
\hline 77 & 4.3 & 2.8 & 1.2 & 16 & 0.65 & 0.43 & 0.279 & 3 & 1 & 5 & BX901 \\
\hline 78 & 4.9 & 3.9 & 1.5 & 17 & 0.8 & 0.38 & 0.306 & 1 & 4 & 5 & . $\quad$ BX901 \\
\hline 79 & 5.5 & 2.9 & 1.1 & 17 & 0.53 & 0.38 & 0.2 & 1 & 1 & 5 & BX901 \\
\hline 80 & 4.2 & 3.3 & 1.3 & 17 & 0.79 & 0.39 & 0.31 & 2 & 1 & 5 & BX901 \\
\hline 81 & 4.2 & 4.1 & 1.2 & 18 & 0.98 & 0.29 & 0.286 & 1 & 2 & 5 & BX901 \\
\hline 82 & 4.2 & 4.5 & 1.3 & 18 & 1.07 & 0.29 & 0.31 & 1 & 2 & 2 & BX901 \\
\hline 83 & 4 & 5 & 0.9 & 19 & 1.25 & 0.18 & 0.225 & 1 & 1 & 2 & BX901 \\
\hline 84 & 3.6 & 3.8 & 1.3 & 19 & 1.06 & 0.34 & 0.361 & 1 & 4 & 5 & BX901 \\
\hline 85 & 4.7 & 4.1 & 1.2 & 19 & 0.87 & 0.29 & 0.255 & 1 & 1 & 2 & BX901 \\
\hline 86 & 3.7 & 4.1 & 1.2 & 19 & 1.11 & 0.29 & 0.324 & 2 & 4 & 1 & BX901 \\
\hline 87 & 5.7 & 3.5 & 1.1 & 20 & 0.61 & 0.31 & 0.193 & 2 & 4 & 2 & BX901 \\
\hline 88 & 3.6 & 3.7 & 1.5 & 21 & 1.03 & 0.41 & 0.417 & 4 & 3 & 5 & BX901 \\
\hline 89 & 3.5 & 4 & 1.7 & 21 & 1.14 & 0.43 & 0.486 & 3 & 1 & 5 & BX901 \\
\hline 90 & 3.6 & 4.8 & 1.2 & 21 & 1.33 & 0.25 & 0.333 & 1 & 1 & 2 & BX901 \\
\hline 91 & 5.1 & 4.7 & 1 & 22 & 0.92 & 0.21 & 0.196 & 1 & 4 & 1 & BX901 \\
\hline 92 & 5.3 & 4.2 & 1 & 23 & 0.79 & 0.24 & 0.189 & 1 & 1 & 5 & BX901 \\
\hline 93 & 5.4 & 4.4 & 0.9 & 23 & 0.81 & 0.2 & 0.167 & 2 & 3 & 2 & BX901 \\
\hline 94 & 4.5 & 5.7 & 1.2 & 23 & 1.27 & 0.21 & 0.267 & 1 & 1 & 2 & BX901 \\
\hline 95 & 4.4 & 5.8 & 1.3 & 24 & 1.32 & 0.22 & 0.295 & 1 & 1 & 2 & BX901 \\
\hline 96 & 5.2 & 4.2 & 1.3 & 24 & 0.81 & 0.31 & 0.25 & 1 & 2 & 5 & BX901 \\
\hline 97 & 4.7 & 3.6 & 1.6 & 24 & 0.77 & 0.44 & 0.34 & 2 & 1 & 2 & BX901 \\
\hline 98 & 4.7 & 4.5 & 1.3 & 25 & 0.96 & 0.29 & 0.277 & 1 & 3 & 5 & BX901 \\
\hline 99 & 3.5 & 4.4 & 1.7 & 27 & 1.26 & 0.39 & 0.486 & 2 & 4 & 2 & BX901 \\
\hline 100 & 7.8 & 3.3 & 1.1 & 27 & 0.42 & 0.33 & 0.141 & 2 & 1 & 2 & BX901 \\
\hline 101 & 6.9 & 4.7 & 1.1 & 27 & 0.68 & 0.23 & 0.159 & 5 & 1 & 6 & BX901 \\
\hline 102 & 5.6 & 4.1 & 1.5 & 28 & 0.73 & 0.37 & 0.268 & 1 & 1 & 2 & BX901 \\
\hline 103 & 3.9 & 5.2 & 1.8 & 28 & 1.33 & 0.35 & 0.462 & 1 & 1 & 7 & BX901 \\
\hline 104 & 7.4 & 4.2 & 1 & 28 & 0.57 & 0.24 & 0.135 & 1 & 1 & 5 & BX901 \\
\hline 105 & 5.5 & 5.9 & 1 & 28 & 1.07 & 0.17 & 0.182 & 4 & 1 & 5 & BX901 \\
\hline 106 & 4.7 & 5 & 1.3 & 28 & 1.06 & 0.26 & 0.277 & 1 & 1 & 5 & BX901 \\
\hline 107 & 4.4 & 2.8 & 1.3 & 29 & 0.64 & 0.46 & 0.298 & 3 & 3 & 2 & BX901 \\
\hline 108 & 6.3 & 4.1 & 1.2 & 30 & 0.65 & 0.29 & 0.19 & 1 & 1 & 5 & BX901 \\
\hline 109 & 5.8 & 5.3 & 1.7 & 30 & 0.91 & 0.32 & 0.293 & 3 & 4 & 2 & BX901 \\
\hline 110 & 6 & 4.3 & 1.6 & 30 & 0.72 & 0.37 & 0.267 & 1 & 2 & 7 & BX901 \\
\hline 111 & 3.8 & 6.2 & 1 & 31 & 1.63 & 0.16 & 0.263 & 3 & 4 & 2 & BX901 \\
\hline 112 & 4.2 & 5.2 & 1.8 & 31 & 1.24 & 0.35 & 0.429 & 1 & 3 & 2 & BX901 \\
\hline 113 & 4.4 & 5.8 & 1.3 & 33 & 1.32 & 0.22 & 0.295 & 3 & 1 & 2 & BX901 \\
\hline 114 & 6.4 & 4.8 & 1.1 & 34 & 0.75 & 0.23 & 0.172 & 4 & 1 & 5 & BX901 \\
\hline 115 & 6.8 & 4 & 1.9 & 34 & 0.59 & 0.48 & 0.279 & 1 & 1 & 7 & BX901 \\
\hline 116 & 5.8 & 4.1 & 1.2 & 36 & 0.71 & 0.29 & 0.207 & 4 & 4 & 5 & BX901 \\
\hline 117 & 3.2 & 6.3 & 2.1 & 36 & 1.97 & 0.33 & 0.656 & 4 & 4 & 5 & . $\quad$ BX901 \\
\hline
\end{tabular}




\begin{tabular}{|c|c|c|c|c|c|c|c|c|c|c|c|}
\hline 118 & 4.7 & 5.8 & 1.4 & 37 & 1.23 & 0.24 & 0.298 & 1 & 1 & 2 & BX901 \\
\hline 119 & 5.1 & 4.5 & 1.7 & 38 & 0.88 & 0.38 & 0.333 & 3 & 1 & 5 & BX901 \\
\hline 120 & 8 & 5.1 & 1.5 & 39 & 0.64 & 0.29 & 0.188 & 1 & 1 & 5 & BX901 \\
\hline 121 & 6.3 & 4.5 & 1.2 & 39 & 0.71 & 0.27 & 0.19 & 4 & 1 & 5 & BX901 \\
\hline 122 & 4.2 & 5.8 & 1.7 & 40 & 1.38 & 0.29 & 0.405 & 3 & 1 & 2 & BX901 \\
\hline 123 & 4.8 & 4.8 & 2.4 & 40 & 1 & 0.5 & 0.5 & 2 & 1 & 4 & BX901 \\
\hline 124 & 6.8 & 4.5 & 1.4 & 44 & 0.66 & 0.31 & 0.206 & 1 & 1 & 5 & BX901 \\
\hline 125 & 5.2 & 7.7 & 1.8 & 46 & 1.48 & 0.23 & 0.346 & 5 & 1 & 2 & BX901 \\
\hline 126 & 7.5 & 3.7 & 1.5 & 46 & 0.49 & 0.41 & 0.2 & 1 & 4 & 1 & BX901 \\
\hline 127 & 5.2 & 8.1 & 1.2 & 48 & 1.56 & 0.15 & 0.231 & 4 & 1 & 2 & BX901 \\
\hline 128 & 6.9 & 6.7 & 1.4 & 49 & 0.97 & 0.21 & 0.203 & 1 & 1 & 2 & BX901 \\
\hline 129 & 4.7 & 6 & 2.1 & 51 & 1.28 & 0.35 & 0.447 & 2 & 1 & 2 & BX901 \\
\hline 130 & 7 & 7.4 & 1.5 & 53 & 1.06 & 0.2 & 0.214 & 1 & 4 & 5 & . $\quad$ BX901 \\
\hline 131 & 7.2 & 6.6 & 2.1 & 53 & 0.92 & 0.32 & 0.292 & 1 & 4 & 2 & BX901 \\
\hline 132 & 7.6 & 3.6 & 1.8 & 54 & 0.47 & 0.5 & 0.237 & 3 & 1 & 5 & BX901 \\
\hline 133 & 7.8 & 3 & 1.8 & 55 & 0.38 & 0.6 & 0.231 & 3 & 1 & 5 & BX901 \\
\hline 134 & 5.5 & 6.4 & 2 & 56 & 1.16 & 0.31 & 0.364 & 1 & 1 & 5 & BX901 \\
\hline 135 & 6.2 & 5.9 & 1.9 & 60 & 0.95 & 0.32 & 0.306 & 1 & 1 & 2 & BX901 \\
\hline 136 & 9.5 & 4.2 & 2.5 & 61 & 0.44 & 0.6 & 0.263 & 2 & 1 & 2 & BX901 \\
\hline 137 & 6.4 & 5 & 1.7 & 61 & 0.78 & 0.34 & 0.266 & 1 & 1 & 2 & BX901 \\
\hline 138 & 6.1 & 5.7 & 1.9 & 65 & 0.93 & 0.33 & 0.311 & 4 & 1 & 5 & BX901 \\
\hline 139 & 6.2 & 7.4 & 1.5 & 65 & 1.19 & 0.2 & 0.242 & 1 & 3 & 5 & BX901 \\
\hline 140 & 7.1 & 5 & 1.8 & 65 & 0.7 & 0.36 & 0.254 & 4 & 1 & 5 & BX901 \\
\hline 141 & 6.4 & 6 & 1.5 & 68 & 0.94 & 0.25 & 0.234 & 1 & 2 & 5 & BX901 \\
\hline 142 & 7.9 & 4.6 & 2.1 & 69 & 0.58 & 0.46 & 0.266 & 2 & 4 & 2 & BX901 \\
\hline 143 & 5.8 & 7.7 & 2.1 & 70 & 1.33 & 0.27 & 0.362 & 1 & 1 & 2 & BX901 \\
\hline 144 & 6.8 & 6.1 & 1.8 & 70 & 0.9 & 0.3 & 0.265 & 4 & 1 & 2 & BX901 \\
\hline 145 & 6.7 & 6.4 & 1.7 & 71 & 0.96 & 0.27 & 0.254 & 1 & 1 & 1 & BX901 \\
\hline 146 & 5.9 & 6.5 & 1.8 & 78 & 1.1 & 0.28 & 0.305 & 3 & 4 & 1 & BX901 \\
\hline 147 & 5.9 & 7.4 & 2.5 & 78 & 1.25 & 0.34 & 0.424 & 1 & 2 & 5 & BX901 \\
\hline 148 & 7.8 & 8.1 & 1.8 & 78 & 1.04 & 0.22 & 0.231 & 1 & 1 & 5 & BX901 \\
\hline 149 & 9.1 & 3 & 3.1 & 79 & 0.33 & 1.03 & 0.341 & 4 & 1 & 5 & BX901 \\
\hline 150 & 5 & 7.6 & 2 & 80 & 1.52 & 0.26 & 0.4 & 4 & 1 & 2 & BX901 \\
\hline 151 & 8.5 & 4.8 & 2.5 & 80 & 0.56 & 0.52 & 0.294 & 1 & 3 & 2 & BX901 \\
\hline 152 & 8.5 & 5.8 & 2 & 81 & 0.68 & 0.34 & 0.235 & 1 & 1 & 5 & BX901 \\
\hline 153 & 5.5 & 7.7 & 1.9 & 82 & 1.4 & 0.25 & 0.345 & 4 & 1 & 2 & BX901 \\
\hline 154 & 6 & 7.3 & 3.1 & 82 & 1.22 & 0.42 & 0.517 & 3 & 1 & 5 & BX901 \\
\hline 155 & 9 & 5.4 & 2.6 & 84 & 0.6 & 0.48 & 0.289 & 1 & 1 & 2 & BX901 \\
\hline 156 & 8.3 & 8.4 & 1.7 & 87 & 1.01 & 0.2 & 0.205 & 3 & 2 & 2 & BX901 \\
\hline 157 & 8 & 5.2 & 2.2 & 91 & 0.65 & 0.42 & 0.275 & 1 & 4 & 2 & BX901 \\
\hline 158 & 9.6 & 7.7 & 1.2 & 94 & 0.8 & 0.16 & 0.125 & 1 & 1 & 5 & BX901 \\
\hline 159 & 8.5 & 7.4 & 2 & 95 & 0.87 & 0.27 & 0.235 & 4 & 3 & 5 & BX901 \\
\hline 160 & 8 & 8 & 1.5 & 98 & 1 & 0.19 & 0.188 & 1 & 1 & 5 & BX901 \\
\hline 161 & 7.8 & 6.8 & 2.8 & 102 & 0.87 & 0.41 & 0.359 & 2 & 1 & 2 & BX901 \\
\hline 162 & 9.5 & 5.7 & 3.4 & 104 & 0.6 & 0.6 & 0.358 & 2 & 1 & 7 & BX901 \\
\hline 163 & 7.8 & 10 & 1.5 & 107 & 1.32 & 0.15 & 0.192 & 4 & 1 & 5 & BX901 \\
\hline 164 & 7.8 & 7.1 & 2.1 & 107 & 0.91 & 0.3 & 0.269 & 1 & 1 & 2 & BX901 \\
\hline 165 & 7.2 & 7.8 & 1.8 & 108 & 1.08 & 0.23 & 0.25 & 2 & 1 & 2 & BX901 \\
\hline 166 & 9.6 & 6.8 & 1.9 & 109 & 0.71 & 0.28 & 0.198 & 4 & 1 & 5 & BX901 \\
\hline 167 & 7.6 & 5.8 & 3 & 110 & 0.76 & 0.52 & 0.395 & 2 & 1 & 2 & BX901 \\
\hline 168 & 9.1 & 7.8 & 2 & 111 & 0.86 & 0.26 & 0.22 & 2 & 1 & 2 & BX901 \\
\hline 169 & 9.2 & 5.6 & 1.9 & 115 & 0.61 & 0.34 & 0.207 & 4 & 1 & 5 & BX901 \\
\hline 170 & 11 & 4.9 & 2.1 & 117 & 0.43 & 0.43 & 0.186 & 2 & 3 & 2 & BX901 \\
\hline 171 & 6.5 & 8 & 2.7 & 123 & 1.23 & 0.34 & 0.415 & 4 & 1 & 2 & BX901 \\
\hline 172 & 5.5 & 11 & 2.8 & 124 & 2.02 & 0.25 & 0.509 & 2 & 4 & 1 & BX901 \\
\hline 173 & 6 & 7.1 & 3 & 125 & 1.18 & 0.42 & 0.5 & 2 & 1 & 7 & BX901 \\
\hline 174 & 7.5 & 7.7 & 2.1 & 128 & 1.03 & 0.27 & 0.28 & 4 & 1 & 2 & BX901 \\
\hline 175 & 6.7 & 8.4 & 2.2 & 130 & 1.25 & 0.26 & 0.328 & 4 & 1 & 5 & $\mathrm{BX} 901$ \\
\hline 176 & 10 & 5.6 & 2.7 & 136 & 0.55 & 0.48 & 0.267 & 1 & 3 & 2 & BX901 \\
\hline
\end{tabular}




\begin{tabular}{|c|c|c|c|c|c|c|c|c|c|c|c|}
\hline 177 & 9.5 & 8.1 & 2.5 & 147 & 0.85 & 0.31 & 0.263 & 2 & 1 & 2 & BX901 \\
\hline 178 & 7.6 & 8.6 & 2.5 & 151 & 1.13 & 0.29 & 0.329 & 4 & 1 & 2 & BX901 \\
\hline 179 & 12 & 6.2 & 2.5 & 152 & 0.52 & 0.4 & 0.208 & 2 & 1 & 2 & BX901 \\
\hline 180 & 11 & 9.2 & 2.4 & 160 & 0.82 & 0.26 & 0.214 & 1 & 3 & 2 & BX901 \\
\hline 181 & 5.7 & 10 & 2.8 & 163 & 1.81 & 0.27 & 0.491 & 4 & 1 & 2 & BX901 \\
\hline 182 & 8.9 & 7.5 & 2.6 & 171 & 0.84 & 0.35 & 0.292 & 4 & 1 & 5 & BX901 \\
\hline 183 & 9.4 & 8.7 & 2.3 & 175 & 0.93 & 0.26 & 0.245 & 4 & 1 & 2 & BX901 \\
\hline 184 & 9.9 & 7.5 & 2 & 194 & 0.76 & 0.27 & 0.202 & 1 & 1 & 2 & BX901 \\
\hline 185 & 15 & 5.1 & 3.1 & 201 & 0.34 & 0.61 & 0.205 & 2 & 1 & 2 & BX901 \\
\hline 186 & 7.1 & 8.3 & 3.7 & 207 & 1.17 & 0.45 & 0.521 & 2 & 1 & 2 & BX901 \\
\hline 187 & 7.8 & 11 & 2.5 & 218 & 1.4 & 0.23 & 0.321 & 4 & 3 & 2 & BX901 \\
\hline 188 & 10 & 11 & 2.8 & 259 & 1.01 & 0.27 & 0.269 & 4 & 1 & 2 & BX901 \\
\hline 189 & 13 & 11 & 2.4 & 260 & 0.81 & 0.23 & 0.185 & 2 & 1 & 5 & BX901 \\
\hline 190 & 7.9 & 11 & 2.9 & 271 & 1.38 & 0.27 & 0.367 & 4 & 2 & 1 & BX901 \\
\hline 191 & 6.4 & 11 & 6.6 & 279 & 1.7 & 0.61 & 1.031 & 2 & 1 & 2 & BX901 \\
\hline 192 & 9.3 & 8.1 & 4 & 284 & 0.87 & 0.49 & 0.43 & 2 & 1 & 7 & BX901 \\
\hline 193 & 10 & 8.9 & 2.8 & 293 & 0.88 & 0.31 & 0.277 & 4 & 4 & 2 & BX901 \\
\hline 194 & 16 & 6.6 & 3.6 & 298 & 0.41 & 0.55 & 0.225 & 2 & 4 & 2 & BX901 \\
\hline 195 & 11 & 9 & 4.2 & 299 & 0.84 & 0.47 & 0.393 & 4 & 1 & 2 & BX901 \\
\hline 196 & 13 & 7.3 & 3.7 & 322 & 0.56 & 0.51 & 0.285 & 2 & 3 & 1 & BX901 \\
\hline 197 & 8.1 & 13 & 3.6 & 327 & 1.65 & 0.27 & 0.444 & 4 & 1 & 2 & BX901 \\
\hline 198 & 11 & 11 & 4.3 & 336 & 1.05 & 0.38 & 0.394 & 2 & 1 & 7 & BX901 \\
\hline 199 & 9.6 & 14 & 3.4 & 439 & 1.5 & 0.24 & 0.354 & 2 & 4 & 2 & BX901 \\
\hline 200 & 12 & 14 & 4.9 & 592 & 1.15 & 0.34 & 0.395 & 2 & 1 & 2 & BX901 \\
\hline 201 & 13 & 14 & 6.2 & 856 & 1.1 & 0.45 & 0.492 & 1 & 1 & 2 & BX901 \\
\hline 202 & 1.1 & 1.1 & 0.2 & 0.3 & 1 & 0.18 & 0.182 & 1 & 2 & 6 & BX903 \\
\hline 203 & 1.2 & 1 & 0.2 & 0.3 & 0.83 & 0.2 & 0.167 & 1 & 3 & 5 & BX903 \\
\hline 204 & 1.4 & 0.9 & 0.2 & 0.3 & 0.64 & 0.22 & 0.143 & 1 & 3 & 6 & BX903 \\
\hline 205 & 1.1 & 0.9 & 0.1 & 0.3 & 0.82 & 0.11 & 0.091 & 1 & 3 & 6 & BX903 \\
\hline 206 & 1.1 & 0.8 & 0.1 & 0.3 & 0.73 & 0.13 & 0.091 & 1 & 3 & 8 & BX903 \\
\hline 207 & 1.3 & 1.1 & 0.1 & 0.3 & 0.85 & 0.09 & 0.077 & 1 & 3 & 5 & BX903 \\
\hline 208 & 1.1 & 1 & 0.1 & 0.3 & 0.91 & 0.1 & 0.091 & 1 & 3 & 6 & BX903 \\
\hline 209 & 1.3 & 0.8 & 0.3 & 0.3 & 0.62 & 0.38 & 0.231 & 1 & 2 & 2 & BX903 \\
\hline 210 & 1.6 & 0.8 & 0.1 & 0.3 & 0.5 & 0.13 & 0.063 & 1 & 3 & 8 & BX903 \\
\hline 211 & 1.4 & 1.3 & 0.1 & 0.4 & 0.93 & 0.08 & 0.071 & 1 & 3 & 6 & BX903 \\
\hline 212 & 1.5 & 1.1 & 0.1 & 0.4 & 0.73 & 0.09 & 0.067 & 1 & 3 & 5 & BX903 \\
\hline 213 & 1.2 & 1.2 & 0.2 & 0.4 & 1 & 0.17 & 0.167 & 1 & 1 & 5 & BX903 \\
\hline 214 & 1.9 & 0.9 & 0.1 & 0.4 & 0.47 & 0.11 & 0.053 & 1 & 2 & 6 & BX903 \\
\hline 215 & 2 & 0.7 & 0.1 & 0.4 & 0.35 & 0.14 & 0.05 & 1 & 3 & 8 & BX903 \\
\hline 216 & 1.3 & 1.4 & 0.2 & 0.4 & 1.08 & 0.14 & 0.154 & 1 & 3 & 6 & BX903 \\
\hline 217 & 1.9 & 1 & 0.1 & 0.4 & 0.53 & 0.1 & 0.053 & 1 & 3 & 6 & BX903 \\
\hline 218 & 1.5 & 1.2 & 0.2 & 0.5 & 0.8 & 0.17 & 0.133 & 1 & 3 & 5 & BX903 \\
\hline 219 & 2.8 & 1.3 & 0.2 & 0.5 & 0.46 & 0.15 & 0.071 & 1 & 3 & 6 & BX903 \\
\hline 220 & 1.4 & 1.5 & 0.2 & 0.5 & 1.07 & 0.13 & 0.143 & 1 & 3 & 6 & BX903 \\
\hline 221 & 1.4 & 1 & 0.2 & 0.5 & 0.71 & 0.2 & 0.143 & 1 & 3 & 6 & BX903 \\
\hline 222 & 1.6 & 1.1 & 0.2 & 0.5 & 0.69 & 0.18 & 0.125 & 1 & 3 & 6 & BX903 \\
\hline 223 & 1.4 & 1.4 & 0.2 & 0.5 & 1 & 0.14 & 0.143 & 1 & 1 & 3 & BX903 \\
\hline 224 & 2 & 1.5 & 0.2 & 0.5 & 0.75 & 0.13 & 0.1 & 1 & 3 & 5 & BX903 \\
\hline 225 & 1.5 & 1.4 & 0.2 & 0.5 & 0.93 & 0.14 & 0.133 & 1 & 3 & 6 & BX903 \\
\hline 226 & 1.4 & 1.3 & 0.2 & 0.5 & 0.93 & 0.15 & 0.143 & 1 & 3 & 6 & BX903 \\
\hline 227 & 1.7 & 1.3 & 0.4 & 0.6 & 0.76 & 0.31 & 0.235 & 1 & 3 & 5 & BX903 \\
\hline 228 & 1.4 & 1.2 & 0.3 & 0.6 & 0.86 & 0.25 & 0.214 & 4 & 3 & 6 & BX903 \\
\hline 229 & 1.3 & 1.5 & 0.2 & 0.6 & 1.15 & 0.13 & 0.154 & 1 & 3 & 6 & BX903 \\
\hline 230 & 1.3 & 1.5 & 0.2 & 0.6 & 1.15 & 0.13 & 0.154 & 1 & 1 & 5 & BX903 \\
\hline 231 & 1.7 & 1.2 & 0.2 & 0.6 & 0.71 & 0.17 & 0.118 & 1 & 3 & 6 & $\mathrm{BX} 903$ \\
\hline 232 & 2.8 & 1.9 & 0.2 & 0.6 & 0.68 & 0.11 & 0.071 & 1 & 3 & 5 & BX903 \\
\hline 233 & 1.5 & 1.2 & 0.3 & 0.6 & 0.8 & 0.25 & 0.2 & 1 & 3 & 6 & BX903 \\
\hline 234 & 1.9 & 1.5 & 0.2 & 0.6 & 0.79 & 0.13 & 0.105 & 1 & 3 & 6 & BX903 \\
\hline 235 & 1.5 & 1.5 & 0.3 & 0.6 & 1 & 0.2 & 0.2 & 1 & 3 & 6 & BX903 \\
\hline
\end{tabular}




\begin{tabular}{|c|c|c|c|c|c|c|c|c|c|c|c|}
\hline 236 & 2 & 1 & 0.3 & 0.6 & 0.5 & 0.3 & 0.15 & 1 & 3 & 5 & BX903 \\
\hline 237 & 1.7 & 2 & 0.4 & 0.7 & 1.18 & 0.2 & 0.235 & 1 & 1 & 5 & BX903 \\
\hline 238 & 1.9 & 1.7 & 0.2 & 0.7 & 0.89 & 0.12 & 0.105 & 1 & 3 & 5 & BX903 \\
\hline 239 & 1.7 & 1.4 & 0.2 & 0.7 & 0.82 & 0.14 & 0.118 & 4 & 3 & 5 & BX903 \\
\hline 240 & 3 & 1.8 & 0.2 & 0.7 & 0.6 & 0.11 & 0.067 & 1 & 1 & 6 & BX903 \\
\hline 241 & 2 & 1.8 & 0.3 & 0.7 & 0.9 & 0.17 & 0.15 & 1 & 1 & 5 & BX903 \\
\hline 242 & 1 & 1.4 & 0.3 & 0.7 & 1.4 & 0.21 & 0.3 & 1 & 1 & 5 & BX903 \\
\hline 243 & 1.8 & 2.2 & 0.2 & 0.7 & 1.22 & 0.09 & 0.111 & 1 & 3 & 6 & BX903 \\
\hline 244 & 1.5 & 1.8 & 0.4 & 0.8 & 1.2 & 0.22 & 0.267 & 1 & 3 & 6 & BX903 \\
\hline 245 & 1.4 & 2.3 & 0.2 & 0.8 & 1.64 & 0.09 & 0.143 & 1 & 3 & 6 & BX903 \\
\hline 246 & 1.7 & 1.7 & 0.3 & 0.9 & 1 & 0.18 & 0.176 & 1 & 2 & 5 & BX903 \\
\hline 247 & 1.4 & 1.8 & 0.5 & 0.9 & 1.29 & 0.28 & 0.357 & 1 & 3 & 6 & BX903 \\
\hline 248 & 2.5 & 1.1 & 0.3 & 1 & 0.44 & 0.27 & 0.12 & 1 & 2 & 5 & BX903 \\
\hline 249 & 1.3 & 1.7 & 0.5 & 1 & 1.31 & 0.29 & 0.385 & 4 & 1 & 2 & BX903 \\
\hline 250 & 2.2 & 1.6 & 0.4 & 1.1 & 0.73 & 0.25 & 0.182 & 1 & 1 & 5 & BX903 \\
\hline 251 & 1.6 & 2.3 & 0.2 & 1.1 & 1.44 & 0.09 & 0.125 & 4 & 3 & 5 & BX903 \\
\hline 252 & 2.2 & 1.5 & 0.3 & 1.1 & 0.68 & 0.2 & 0.136 & 1 & 3 & 5 & BX903 \\
\hline 253 & 1.5 & 2.5 & 0.3 & 1.2 & 1.67 & 0.12 & 0.2 & 1 & 1 & 5 & BX903 \\
\hline 254 & 2.6 & 1.3 & 0.3 & 1.2 & 0.5 & 0.23 & 0.115 & 1 & 4 & 6 & BX903 \\
\hline 255 & 1.9 & 2 & 0.5 & 1.3 & 1.05 & 0.25 & 0.263 & 1 & 3 & 3 & BX903 \\
\hline 256 & 2.9 & 2.2 & 0.3 & 1.4 & 0.76 & 0.14 & 0.103 & 1 & 3 & 6 & BX903 \\
\hline 257 & 1.9 & 2.1 & 0.4 & 1.5 & 1.11 & 0.19 & 0.211 & 1 & 1 & 5 & BX903 \\
\hline 258 & 2.2 & 2.2 & 0.3 & 1.5 & 1 & 0.14 & 0.136 & 1 & 3 & 6 & BX903 \\
\hline 259 & 1.8 & 3.2 & 0.4 & 1.6 & 1.78 & 0.13 & 0.222 & 1 & 3 & 5 & BX903 \\
\hline 260 & 3.5 & 2 & 0.2 & 1.7 & 0.57 & 0.1 & 0.057 & 1 & 3 & 5 & BX903 \\
\hline 261 & 2.5 & 3 & 0.3 & 1.7 & 1.2 & 0.1 & 0.12 & 4 & 3 & 6 & BX903 \\
\hline 262 & 2.8 & 1.5 & 0.5 & 1.7 & 0.54 & 0.33 & 0.179 & 2 & 3 & 2 & BX903 \\
\hline 263 & 2.5 & 1.5 & 0.5 & 1.7 & 0.6 & 0.33 & 0.2 & 1 & 3 & 5 & BX903 \\
\hline 264 & 2.2 & 1.9 & 0.5 & 1.8 & 0.86 & 0.26 & 0.227 & 3 & 3 & 5 & BX903 \\
\hline 265 & 3.5 & 1.5 & 0.4 & 1.9 & 0.43 & 0.27 & 0.114 & 1 & 4 & 5 & BX903 \\
\hline 266 & 2.8 & 2.5 & 0.3 & 1.9 & 0.89 & 0.12 & 0.107 & 1 & 3 & 6 & BX903 \\
\hline 267 & 1.6 & 2.6 & 0.5 & 1.9 & 1.63 & 0.19 & 0.313 & 1 & 2 & 5 & BX903 \\
\hline 268 & 3.2 & 1.9 & 0.3 & 2 & 0.59 & 0.16 & 0.094 & 1 & 3 & 6 & BX903 \\
\hline 269 & 2.9 & 1.7 & 0.3 & 2 & 0.59 & 0.18 & 0.103 & 1 & 1 & 5 & BX903 \\
\hline 270 & 3 & 1.8 & 0.4 & 2.1 & 0.6 & 0.22 & 0.133 & 1 & 3 & 6 & BX903 \\
\hline 271 & 4 & 2.1 & 0.2 & 2.2 & 0.53 & 0.1 & 0.05 & 1 & 3 & 6 & BX903 \\
\hline 272 & 3.9 & 3.1 & 0.2 & 2.3 & 0.79 & 0.06 & 0.051 & 1 & 3 & 6 & BX903 \\
\hline 273 & 3.5 & 1.7 & 0.5 & 2.4 & 0.49 & 0.29 & 0.143 & 1 & 3 & 2 & BX903 \\
\hline 274 & 2.7 & 1.7 & 0.7 & 2.5 & 0.63 & 0.41 & 0.259 & 1 & 3 & 6 & BX903 \\
\hline 275 & 1.4 & 1.7 & 0.3 & 2.6 & 1.21 & 0.18 & 0.214 & 1 & 3 & 2 & BX903 \\
\hline 276 & 2.2 & 2.3 & 0.5 & 2.8 & 1.05 & 0.22 & 0.227 & 1 & 2 & 5 & BX903 \\
\hline 277 & 3 & 2.4 & 0.3 & 2.9 & 0.8 & 0.13 & 0.1 & 1 & 3 & 6 & BX903 \\
\hline 278 & 4.7 & 2.5 & 0.3 & 3 & 0.53 & 0.12 & 0.064 & 1 & 3 & 6 & BX903 \\
\hline 279 & 4.6 & 2.5 & 0.3 & 3.1 & 0.54 & 0.12 & 0.065 & 1 & 3 & 6 & BX903 \\
\hline 280 & 3.8 & 2.1 & 0.5 & 3.2 & 0.55 & 0.24 & 0.132 & 1 & 3 & 5 & BX903 \\
\hline 281 & 4.2 & 2.3 & 0.3 & 3.3 & 0.55 & 0.13 & 0.071 & 1 & 3 & 6 & BX903 \\
\hline 282 & 3.3 & 2.4 & 0.6 & 3.6 & 0.73 & 0.25 & 0.182 & 1 & 3 & 5 & BX903 \\
\hline 283 & 3.1 & 2.5 & 0.6 & 3.8 & 0.81 & 0.24 & 0.194 & 1 & 1 & 5 & BX903 \\
\hline 284 & 3.6 & 3.5 & 0.5 & 4.2 & 0.97 & 0.14 & 0.139 & 1 & 3 & 6 & BX903 \\
\hline 285 & 4 & 3.5 & 0.5 & 5.7 & 0.88 & 0.14 & 0.125 & 1 & 3 & 5 & BX903 \\
\hline 286 & 4.9 & 2.9 & 0.5 & 6 & 0.59 & 0.17 & 0.102 & 1 & 3 & 5 & BX903 \\
\hline 287 & 4.9 & 2 & 0.9 & 6.1 & 0.41 & 0.45 & 0.184 & 1 & 1 & 5 & BX903 \\
\hline 288 & 3.5 & 3.2 & 0.8 & 6.5 & 0.91 & 0.25 & 0.229 & 1 & 3 & 6 & $\mathrm{BX} 903$ \\
\hline 289 & 6.3 & 2.1 & 0.5 & 6.6 & 0.33 & 0.24 & 0.079 & 1 & 4 & 5 & BX903 \\
\hline 290 & 1.9 & 1.2 & 0.3 & 7 & 0.63 & 0.25 & 0.158 & 1 & 3 & 5 & BX903 \\
\hline 291 & 3 & 5.1 & 0.7 & 7.5 & 1.7 & 0.14 & 0.233 & 1 & 1 & 2 & BX903 \\
\hline .292 & 5.2 & 5.1 & 0.5 & 9.6 & 0.98 & 0.1 & 0.096 & 1 & 3 & 5 & BX903 \\
\hline 293 & 5.2 & 3 & 0.8 & 10 & 0.58 & 0.27 & 0.154 & 1 & 3 & 5 & BX903 \\
\hline 294 & 3.6 & 3.9 & 0.8 & 11 & 1.08 & 0.21 & 0.222 & 4 & 1 & 5 & . $\quad \mathrm{BX} 903$ \\
\hline
\end{tabular}




\begin{tabular}{|c|c|c|c|c|c|c|c|c|c|c|c|}
\hline 295 & 5.2 & 5.5 & 0.8 & 12 & 1.06 & 0.15 & 0.154 & 1 & 3 & 5 & BX903 \\
\hline 296 & 5.2 & 3.7 & 0.8 & 12 & 0.71 & 0.22 & 0.154 & 1 & 3 & 6 & BX903 \\
\hline 297 & 5.5 & 5 & 0.6 & 15 & 0.91 & 0.12 & 0.109 & 4 & 1 & 2 & BX903 \\
\hline 298 & 4.9 & 4.8 & 0.8 & 15 & 0.98 & 0.17 & 0.163 & 1 & 3 & 6 & BX903 \\
\hline 299 & 5.9 & 3.8 & 0.6 & 16 & 0.64 & 0.16 & 0.102 & 1 & 3 & 3 & BX903 \\
\hline 300 & 5.6 & 4.9 & 0.8 & 17 & 0.88 & 0.16 & 0.143 & 4 & 2 & 5 & BX903 \\
\hline 301 & 6.1 & 5.8 & 0.9 & 22 & 0.95 & 0.16 & 0.148 & 1 & 1 & 3 & BX903 \\
\hline 302 & 6.7 & 4.3 & 1.3 & 43 & 0.64 & 0.3 & 0.194 & 1 & 1 & 2 & BX903 \\
\hline 303 & 0.8 & 0.8 & 0.1 & 0.1 & 1 & 0.13 & 0.125 & 1 & 3 & 5 & BX904 \\
\hline 304 & 1.5 & 1.6 & 0.3 & 0.1 & 1.07 & 0.19 & 0.2 & 1 & 3 & 6 & BX904 \\
\hline 305 & 1.1 & 1.2 & 0.1 & 0.1 & 1.09 & 0.08 & 0.091 & 1 & 3 & 5 & BX904 \\
\hline 306 & 1.3 & 1.2 & 0.3 & 0.2 & 0.92 & 0.25 & 0.231 & 1 & 3 & 5 & BX904 \\
\hline 307 & 1.7 & 1.5 & 0.2 & 0.4 & 0.88 & 0.13 & 0.118 & 1 & 2 & 6 & BX904 \\
\hline 308 & 1.5 & 1.8 & 0.3 & 0.7 & 1.2 & 0.17 & 0.2 & 1 & 3 & 5 & BX904 \\
\hline 309 & 2.3 & 2.1 & 0.2 & 0.7 & 0.91 & 0.1 & 0.087 & 1 & 3 & 5 & BX904 \\
\hline 310 & 1.4 & 1.7 & 0.5 & 0.7 & 1.21 & 0.29 & 0.357 & 1 & 4 & 5 & BX904 \\
\hline 311 & 2.3 & 2 & 0.4 & 1.5 & 0.87 & 0.2 & 0.174 & 4 & 3 & 6 & BX904 \\
\hline 312 & 2.2 & 2.6 & 0.5 & 1.8 & 1.18 & 0.19 & 0.227 & 1 & 3 & 5 & BX904 \\
\hline 313 & 2.8 & 1.7 & 0.4 & 1.8 & 0.61 & 0.24 & 0.143 & 1 & 1 & 5 & BX904 \\
\hline 314 & 1.4 & 2.8 & 0.6 & 2.1 & 2 & 0.21 & 0.429 & 4 & 4 & 1 & BX904 \\
\hline 315 & 3.3 & 2.2 & 0.4 & 2.4 & 0.67 & 0.18 & 0.121 & 1 & 3 & 6 & BX904 \\
\hline 316 & 2.7 & 3.1 & 0.6 & 4.2 & 1.15 & 0.19 & 0.222 & 4 & 4 & 5 & BX904 \\
\hline 317 & 2.9 & 3.3 & 0.6 & 4.8 & 1.14 & 0.18 & 0.207 & 1 & 3 & 5 & BX904 \\
\hline 318 & 2.5 & 3.5 & 1 & 5 & 1.4 & 0.29 & 0.4 & 1 & 1 & 2 & BX904 \\
\hline 319 & 2.9 & 3.7 & 0.9 & 7.1 & 1.28 & 0.24 & 0.31 & 2 & 1 & 2 & BX904 \\
\hline 320 & 3.6 & 3.1 & 0.8 & 7.1 & 0.86 & 0.26 & 0.222 & 1 & 4 & 5 & BX904 \\
\hline 321 & 5.4 & 3.1 & 0.5 & 8.3 & 0.57 & 0.16 & 0.093 & 4 & 1 & 5 & BX904 \\
\hline 322 & 5.1 & 3.2 & 1.2 & 17 & 0.63 & 0.38 & 0.235 & 1 & 2 & 5 & BX904 \\
\hline 323 & 3.7 & 5 & 1.5 & 19 & 1.35 & 0.3 & 0.405 & 2 & 1 & 1 & BX904 \\
\hline 324 & 6.6 & 3.7 & 1.3 & 25 & 0.56 & 0.35 & 0.197 & 1 & 1 & 2 & BX904 \\
\hline 325 & 6.1 & 4.1 & 1.5 & 47 & 0.67 & 0.37 & 0.246 & 2 & 2 & 4 & BX904 \\
\hline 326 & 2.2 & 2 & 0.9 & 1.7 & 0.91 & 0.45 & 0.409 & 1 & 3 & 5 & BX904 \\
\hline 327 & 1.8 & 1.5 & 0.4 & 0.8 & 0.83 & 0.27 & 0.222 & 1 & 3 & 6 & BX904 \\
\hline 328 & 2.4 & 2 & 0.6 & 1.7 & 0.83 & 0.3 & 0.25 & 1 & 1 & 2 & BX904 \\
\hline 329 & 2.4 & 2.3 & 0.7 & 2.8 & 0.96 & 0.3 & 0.292 & 1 & 3 & 6 & BX904 \\
\hline 330 & 1.2 & 1.4 & 0.2 & 0.3 & 1.17 & 0.14 & 0.167 & 1 & 3 & 5 & BX904 \\
\hline 331 & 2.1 & 0.8 & 0.3 & 0.3 & 0.38 & 0.38 & 0.143 & 1 & 3 & 6 & BX904 \\
\hline 332 & 1.3 & 1.1 & 0.5 & 0.6 & 0.85 & 0.45 & 0.385 & 1 & 2 & 5 & BX904 \\
\hline 333 & 2.1 & 2 & 0.3 & 0.4 & 0.95 & 0.15 & 0.143 & 4 & 1 & 2 & BX904 \\
\hline 334 & 1.5 & 0.8 & 0.2 & 0.2 & 0.53 & 0.25 & 0.133 & 1 & 3 & 6 & BX904 \\
\hline 335 & 1.3 & 1.2 & 0.4 & 0.4 & 0.92 & 0.33 & 0.308 & 1 & 1 & 5 & BX904 \\
\hline 336 & 0.8 & 0.9 & 0.1 & 0.1 & 1.13 & 0.11 & 0.125 & 1 & 3 & 5 & BX904 \\
\hline 337 & 2.3 & 2.2 & 0.3 & 1.3 & 0.96 & 0.14 & 0.13 & 2 & 3 & 6 & BX904 \\
\hline 338 & 0.9 & 0.8 & 0.2 & 0.1 & 0.89 & 0.25 & 0.222 & 1 & 3 & 5 & BX904 \\
\hline 339 & 1.6 & 1.6 & 0.3 & 0.4 & 1 & 0.19 & 0.188 & 1 & 3 & 5 & BX904 \\
\hline 340 & 2.2 & 1.4 & 0.3 & 0.6 & 0.64 & 0.21 & 0.136 & 1 & 3 & 5 & BX904 \\
\hline 341 & 0.9 & 1.5 & 0.3 & 0.3 & 1.67 & 0.2 & 0.333 & 1 & 1 & 5 & BX904 \\
\hline 342 & 2.2 & 1.3 & 0.3 & 0.7 & 0.59 & 0.23 & 0.136 & 1 & 3 & 6 & BX904 \\
\hline 343 & 2.9 & 1.9 & 0.7 & 3.5 & 0.66 & 0.37 & 0.241 & 2 & 3 & 5 & BX904 \\
\hline 344 & 1 & 0.7 & 0.2 & 0.1 & 0.7 & 0.29 & 0.2 & 1 & 3 & 5 & BX904 \\
\hline 345 & 1.2 & 1.1 & 0.3 & 0.3 & 0.92 & 0.27 & 0.25 & 1 & 3 & 5 & BX904 \\
\hline 346 & 0.7 & 0.9 & 0.3 & 0.1 & 1.29 & 0.33 & 0.429 & 2 & 1 & 6 & BX904 \\
\hline 347 & 2.7 & 1.2 & 0.2 & 0.5 & 0.44 & 0.17 & 0.074 & 1 & 1 & 5 & BX904 \\
\hline 348 & 2.3 & 1.7 & 0.3 & 1.1 & 0.74 & 0.18 & 0.13 & 4 & 2 & 5 & BX904 \\
\hline 349 & 2.1 & 0.9 & 0.3 & 0.6 & 0.43 & 0.33 & 0.143 & 4 & 1 & 6 & BX904 \\
\hline 350 & 1.9 & 1.8 & 0.5 & 1.6 & 0.95 & 0.28 & 0.263 & 2 & 2 & 2 & BX904 \\
\hline 351 & 1.8 & 1.7 & 0.3 & 0.7 & 0.94 & 0.18 & 0.167 & 1 & 3 & 2 & BX904 \\
\hline 352 & 1.2 & 1.3 & 0.2 & 0.3 & 1.08 & 0.15 & 0.167 & 4 & 1 & 5 & BX904 \\
\hline 353 & 0.8 & 1.4 & 0.2 & 0.3 & 1.75 & 0.14 & 0.25 & 4 & 2 & 5 & BX904 \\
\hline
\end{tabular}




\begin{tabular}{|c|c|c|c|c|c|c|c|c|c|c|c|}
\hline 354 & 5.3 & 5.1 & 1.1 & 40 & 0.95 & 0.22 & 0.212 & . & . & . & $\mathrm{BX} 300$ \\
\hline 355 & 5.6 & 5.8 & 1.8 & 69 & 1.02 & 0.31 & 0.317 & . & . & . & $\mathrm{BX} 300$ \\
\hline 356 & 7.7 & 5.3 & 1.8 & 54 & 0.68 & 0.34 & 0.23 & . & . & . & $\mathrm{BX} 300$ \\
\hline 357 & 6.5 & 2.8 & 1.7 & 28 & 0.42 & 0.63 & 0.265 & . & . & . & $\mathrm{BX} 300$ \\
\hline 358 & 5 & 4.2 & 2.2 & 45 & 0.84 & 0.53 & 0.451 & . & . & . & $\mathrm{BX} 300$ \\
\hline 359 & 4.1 & 3.4 & 0.9 & 13 & 0.82 & 0.25 & 0.208 & . & . & . & $\mathrm{BX} 300$ \\
\hline 360 & 8 & 3.4 & 0.8 & 29 & 0.42 & 0.23 & 0.095 & . & . & . & $\mathrm{BX} 300$ \\
\hline 361 & 6.1 & 4.2 & 1.6 & 40 & 0.7 & 0.38 & 0.261 & . & . & . & $\mathrm{BX} 300$ \\
\hline 362 & 3.8 & 9.5 & 2.2 & 74 & 2.48 & 0.23 & 0.564 & . & . & . & . $\quad \mathrm{BX} 300$ \\
\hline 363 & 5.5 & 4.8 & 1.5 & 48 & 0.88 & 0.3 & 0.269 & . & . & . & $\mathrm{BX} 300$ \\
\hline 364 & 6.5 & 5 & 2.1 & 65 & 0.76 & 0.42 & 0.32 & . & . & . & $\mathrm{BX} 300$ \\
\hline 365 & 5.6 & 4.7 & 2 & 46 & 0.83 & 0.42 & 0.348 & . & . & . & . $\quad \mathrm{BX} 300$ \\
\hline 366 & 5.3 & 3.9 & 1.8 & 35 & 0.74 & 0.46 & 0.34 & . & . & . & . $\mathrm{BX} 300$ \\
\hline 367 & 5.4 & 5.5 & 1.3 & 32 & 1.02 & 0.24 & 0.241 & . & . & . & . $\quad \mathrm{BX} 300$ \\
\hline 368 & 7 & 5.1 & 1.5 & 58 & 0.73 & 0.29 & 0.211 & . & . & . & . $\quad \mathrm{B} \times 300$ \\
\hline 369 & 4.8 & 5.5 & 1.5 & 43 & 1.15 & 0.27 & 0.315 & . & . & . & . $\quad \mathrm{BX} 300$ \\
\hline 370 & 4.2 & 4.1 & 1.2 & 21 & 0.99 & 0.3 & 0.295 & . & . & . & . $\quad \mathrm{BX} 300$ \\
\hline 371 & 3.5 & 3 & 1.3 & 15 & 0.85 & 0.42 & 0.357 & . & . & . & $\mathrm{BX} 300$ \\
\hline 372 & 7.1 & 2.8 & 1.4 & 26 & 0.39 & 0.51 & 0.2 & . & . & . & . $\quad \mathrm{BX} 300$ \\
\hline 373 & 5.2 & 3.8 & 1.4 & 33 & 0.72 & 0.37 & 0.263 & . & . & . & . $\quad \mathrm{BX} 300$ \\
\hline 374 & 6.4 & 2.9 & 1.6 & 38 & 0.46 & 0.56 & 0.257 & . & . & . & . $\mathrm{B} \times 300$ \\
\hline 375 & 5.9 & 5.4 & 1.4 & 41 & 0.91 & 0.27 & 0.244 & . & . & . & BX300 \\
\hline 376 & 3.8 & 2.4 & 1 & 10 & 0.63 & 0.4 & 0.25 & 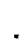 & . & . & . $\quad \mathrm{BX} 300$ \\
\hline 377 & 3.4 & 2.6 & 1.1 & 10 & 0.77 & 0.41 & 0.315 & . & . & . & . $\quad \mathrm{BX} 300$ \\
\hline 378 & 6.5 & 7.5 & 2.2 & 109 & 1.16 & 0.3 & 0.347 & . & . & . & $\mathrm{BX} 300$ \\
\hline 379 & 9.2 & 5.3 & 2.2 & 79 & 0.57 & 0.42 & 0.242 & . & . & . & . $\mathrm{BX} 300$ \\
\hline 380 & 4.4 & 3.9 & 1.6 & 26 & 0.88 & 0.42 & 0.375 & . & . & . & . $\quad \mathrm{B} \times 300$ \\
\hline 381 & 4.5 & 5.1 & 1.3 & 34 & 1.14 & 0.25 & 0.285 & . & . & . & $\mathrm{BX} 300$ \\
\hline 382 & 4.2 & 5.5 & 1.3 & 34 & 1.32 & 0.23 & 0.308 & . & . & . & $\mathrm{BX} 300$ \\
\hline 383 & 6 & 2.8 & 1 & 15 & 0.47 & 0.34 & 0.16 & . & . & . & $\mathrm{BX} 300$ \\
\hline 384 & 7.2 & 4.4 & 2.2 & 69 & 0.61 & 0.5 & 0.304 & . & . & . & . $\mathrm{BX} 300$ \\
\hline 385 & 4.7 & 3.6 & 1.3 & 19 & 0.77 & 0.36 & 0.277 & . & . & . & $\mathrm{BX} 300$ \\
\hline 386 & 2.3 & 2.3 & 0.6 & 2.8 & 1 & 0.24 & 0.243 & . & . & . & . $\mathrm{BX} 300$ \\
\hline 387 & 2.9 & 2.2 & 1.3 & 6.7 & 0.74 & 0.6 & 0.448 & . & . & . & $\mathrm{B} \times 300$ \\
\hline 388 & 8.1 & 6.3 & 3.2 & 142 & 0.77 & 0.5 & 0.39 & . & . & . & BX 300 \\
\hline 389 & 7.7 & 6.3 & 2.3 & 100 & 0.82 & 0.37 & 0.303 & . & . & . & $\mathrm{BX} 300$ \\
\hline 390 & 8.1 & 5.4 & 1.9 & 82 & 0.66 & 0.35 & 0.233 & . & . & . & . $\quad \mathrm{BX} 300$ \\
\hline 391 & 11 & 5 & 2 & 106 & 0.45 & 0.4 & 0.18 & . & . & . & . $\quad \mathrm{BX} 300$ \\
\hline 392 & 5.1 & 5.4 & 1.5 & 53 & 1.07 & 0.28 & 0.298 & . & . & . & BX300 \\
\hline 393 & 9 & 7.3 & 3.1 & 159 & 0.81 & 0.42 & 0.34 & . & . & . & $\mathrm{BX} 300$ \\
\hline 394 & 4 & 3.7 & 1 & 16 & 0.93 & 0.27 & 0.249 & . & . & . & $\mathrm{BX} 300$ \\
\hline 395 & 5.1 & 4.3 & 2.3 & 41 & 0.84 & 0.53 & 0.448 & . & . & . & $\mathrm{BX} 300$ \\
\hline 396 & 5.6 & 4.5 & 1.5 & 35 & 0.81 & 0.34 & 0.276 & . & . & . & $\mathrm{BX} 300$ \\
\hline 397 & 7.4 & 6.9 & 2.1 & 123 & 0.93 & 0.3 & 0.278 & . & . & . & $\mathrm{BX} 300$ \\
\hline 398 & 10 & 6.4 & 1.4 & 101 & 0.62 & 0.22 & 0.137 & . & . & . & $\mathrm{BX} 300$ \\
\hline 399 & 2.1 & 2.3 & 0.4 & 3 & 1.1 & 0.19 & 0.207 & . & . & . & $\mathrm{BX} 300$ \\
\hline 400 & 7.5 & 5.8 & 3.5 & 137 & 0.77 & 0.6 & 0.465 & . & . & . & $\mathrm{BX} 300$ \\
\hline 401 & 4.4 & 3.4 & 1 & 15 & 0.77 & 0.29 & 0.223 & . & . & . & . $\mathrm{BX} 300$ \\
\hline 402 & 4.3 & 2.4 & 1 & 9.5 & 0.56 & 0.42 & 0.236 & . & . & . & $\mathrm{BX} 300$ \\
\hline 403 & 5.6 & 3.3 & 1.8 & 41 & 0.6 & 0.54 & 0.325 & . & . & . & $\mathrm{BX} 300$ \\
\hline 404 & 3.9 & 3.3 & 1.2 & 15 & 0.84 & 0.35 & 0.297 & . & . & . & $\mathrm{BX} 300$ \\
\hline 405 & 8.7 & 6.1 & 3.9 & 204 & 0.7 & 0.63 & 0.442 & . & . & . & $\mathrm{BX} 300$ \\
\hline 406 & 4.7 & 3.2 & 1.6 & 26 & 0.68 & 0.5 & 0.339 & . & . & . & $\mathrm{BX} 300$ \\
\hline 407 & 5.5 & 4.5 & 1.7 & 36 & 0.83 & 0.37 & 0.31 & . & . & . & $\mathrm{BX} 300$ \\
\hline 408 & 5 & 3.9 & 1.3 & 30 & 0.78 & 0.34 & 0.266 & . & . & . & $\mathrm{BX} 300$ \\
\hline 409 & 2.9 & 2.8 & 0.6 & 5.6 & 0.96 & 0.21 & 0.198 & . & . & . & $\mathrm{BX} 300$ \\
\hline 410 & 5.6 & 5.5 & 1.9 & 60 & 0.99 & 0.35 & 0.347 & . & . & . & $\mathrm{BX} 300$ \\
\hline 411 & 4.5 & 3.7 & 1.8 & 30 & 0.81 & 0.5 & 0.405 & . & . & . & $\mathrm{BX} 300$ \\
\hline 412 & 5.6 & 3.1 & 1.7 & 30 & 0.55 & 0.54 & 0.296 & . & . & . & $\mathrm{B} \times 300$ \\
\hline
\end{tabular}




\begin{tabular}{|c|c|c|c|c|c|c|c|c|c|c|c|c|}
\hline 413 & 5.1 & 2.9 & 1 & 12 & 0.57 & 0.33 & 0.188 & . & 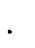 & 5 & . & ZV83 \\
\hline 414 & 1.8 & 1.6 & 0.7 & 1.7 & 0.87 & 0.42 & 0.365 & . & . & 5 & . & ZV83 \\
\hline 415 & 2.3 & 1.4 & 1.3 & 3.7 & 0.63 & 0.93 & 0.581 & . & . & 5 & . & ZV83 \\
\hline 416 & 2.7 & 2.8 & 0.6 & 5.3 & 1.06 & 0.23 & 0.238 & . & . & 5 & . & ZV83 \\
\hline 417 & 5.9 & 2.2 & 2 & 15 & 0.37 & 0.9 & 0.335 & . & . & 2 & . & ZV83 \\
\hline 418 & 6.2 & 3.5 & 0.9 & 11 & 0.57 & 0.25 & 0.142 & . & . & 5 & . & ZV83 \\
\hline 419 & 3.7 & 3.1 & 0.6 & 6.1 & 0.84 & 0.18 & 0.151 & . & . & 2 & . & ZV83 \\
\hline 420 & 4.4 & 2.5 & 1 & 12 & 0.57 & 0.4 & 0.228 & . & . & 2 & . & ZV83 \\
\hline 421 & 2.7 & 2.2 & 0.6 & 3.1 & 0.83 & 0.25 & 0.211 & . & . & 5 & . & ZV83 \\
\hline 422 & 4.4 & 2.6 & 0.7 & 7.4 & 0.58 & 0.28 & 0.16 & . & . & 5 & . & ZV83 \\
\hline 423 & 5.7 & 4.7 & 1.8 & 52 & 0.82 & 0.39 & 0.317 & . & . & 5 & . & ZV83 \\
\hline 424 & 2.8 & 2.6 & 0.9 & 7.4 & 0.94 & 0.36 & 0.337 & . & . & 2 & . & ZV83 \\
\hline 425 & 3.5 & 2.8 & 0.6 & 3.5 & 0.8 & 0.22 & 0.174 & . & . & 2 & . & ZV83 \\
\hline 426 & 2.4 & 1.4 & 0.4 & 1.7 & 0.59 & 0.3 & 0.178 & . & . & 2 & . & ZV83 \\
\hline 427 & 2.5 & 2 & 0.5 & 4 & 0.8 & 0.27 & 0.211 & . & . & 2 & . & ZV83 \\
\hline 428 & 5.5 & 2.2 & 1 & 11 & 0.41 & 0.42 & 0.173 & . & . & 2 & . & ZV83 \\
\hline 429 & 5 & 3.9 & 1.8 & 31 & 0.78 & 0.46 & 0.36 & . & . & 2 & . & ZV83 \\
\hline 430 & 3.3 & 2.1 & 0.5 & 2.3 & 0.62 & 0.23 & 0.143 & . & . & 5 & . & ZV83 \\
\hline 431 & 2 & 1.5 & 0.5 & 1.3 & 0.77 & 0.29 & 0.225 & . & . & 2 & . & ZV83 \\
\hline 432 & 2.4 & 2.4 & 0.5 & 3.3 & 1.01 & 0.22 & 0.223 & . & . & 5 & . & ZV83 \\
\hline 433 & 2.4 & 1.6 & 0.3 & 1.4 & 0.67 & 0.17 & 0.117 & . & . & 5 & . & ZV83 \\
\hline 434 & 2.9 & 2.9 & 1.1 & 13 & 0.98 & 0.37 & 0.358 & . & . & 2 & . & ZV83 \\
\hline 435 & 4.2 & 3.2 & 0.8 & 13 & 0.75 & 0.26 & 0.198 & . & . & 2 & . & ZV83 \\
\hline 436 & 2.1 & 1.2 & 0.6 & 1.7 & 0.59 & 0.45 & 0.262 & . & . & 5 & . & ZV83 \\
\hline 437 & 3.6 & 2.5 & 1.1 & 6.4 & 0.69 & 0.46 & 0.32 & . & . & 5 & . & ZV83 \\
\hline 438 & 2.5 & 2.2 & 0.6 & 3.1 & 0.89 & 0.25 & 0.223 & . & . & 5 & . & ZV83 \\
\hline 439 & 2.5 & 1.8 & 0.7 & 3 & 0.7 & 0.38 & 0.262 & . & . & 5 & . & ZV83 \\
\hline 440 & 3 & 2.1 & 0.6 & 5.7 & 0.71 & 0.26 & 0.186 & . & . & 5 & . & ZV83 \\
\hline 441 & 2.3 & 1.6 & 0.5 & 3.4 & 0.71 & 0.33 & 0.232 & . & . & 5 & . & ZV83 \\
\hline 442 & 2.3 & 2 & 0.6 & 2.6 & 0.89 & 0.32 & 0.283 & . & . & 5 & . & ZV83 \\
\hline 443 & 3.1 & 2.9 & 0.5 & 2.8 & 0.95 & 0.15 & 0.147 & . & . & 5 & . & ZV83 \\
\hline 444 & 2.8 & 3 & 0.9 & 20 & 1.09 & 0.3 & 0.331 & . & . & 2 & . & ZV83 \\
\hline 445 & 3.8 & 2.7 & 1 & 7.1 & 0.71 & 0.36 & 0.255 & . & . & 5 & . & ZV83 \\
\hline 446 & 2.6 & 0.8 & 0.5 & 1.4 & 0.32 & 0.55 & 0.173 & . & . & 2 & . & ZV83 \\
\hline 447 & 2.3 & 4.2 & 1.6 & 9.3 & 1.83 & 0.38 & 0.696 & 2 & 1 & 5 & 1 & GOODE \\
\hline 448 & 5.3 & 2.4 & 1.1 & 9.1 & 0.45 & 0.46 & 0.208 & 1 & 3 & 2 & 1 & GOODE \\
\hline 449 & 3.9 & 2.1 & 0.5 & 2.4 & 0.54 & 0.24 & 0.128 & 1 & 2 & 5 & 1 & GOODE \\
\hline 450 & 4.3 & 4 & 0.7 & 8 & 0.93 & 0.18 & 0.163 & 4 & 4 & 5 & 1 & GOODE \\
\hline 451 & 4.2 & 4.7 & 0.9 & 12 & 1.12 & 0.19 & 0.214 & 2 & 1 & 5 & 1 & GOODE \\
\hline 452 & 5.1 & 3.7 & 1.1 & 9.6 & 0.73 & 0.3 & 0.216 & 1 & 4 & 5 & 1 & GOODE \\
\hline 453 & 7.1 & 7 & 1.9 & 65 & 0.99 & 0.27 & 0.268 & 2 & 3 & 2 & 1 & GOODE \\
\hline 454 & 5 & 4.8 & 1.2 & 17 & 0.96 & 0.25 & 0.24 & 4 & 1 & 2 & 1 & GOODE \\
\hline 455 & 2.2 & 3.5 & 0.4 & 2.2 & 1.59 & 0.11 & 0.182 & 4 & 3 & 5 & 1 & GOODE \\
\hline 456 & 3.9 & 3.2 & 0.6 & 5.6 & 0.82 & 0.19 & 0.154 & 1 & 1 & 5 & 1 & GOODE \\
\hline 457 & 3.7 & 3 & 0.7 & 6.3 & 0.81 & 0.23 & 0.189 & 4 & 1 & 5 & 1 & GOODE \\
\hline 458 & 2.8 & 3.6 & 0.6 & 3.7 & 1.29 & 0.17 & 0.214 & 3 & 4 & 5 & 1 & GOODE \\
\hline 459 & 2.2 & 3.1 & 0.5 & 3.3 & 1.41 & 0.16 & 0.227 & 3 & 1 & 5 & 1 & GOODE \\
\hline 460 & 2.5 & 2.6 & 0.7 & 3.5 & 1.04 & 0.27 & 0.28 & 4 & 2 & 5 & 1 & GOODE \\
\hline 461 & 5.1 & 1.5 & 0.6 & 3.4 & 0.29 & 0.4 & 0.118 & 1 & 3 & 2 & 1 & GOODE \\
\hline 462 & 3.3 & 1.9 & 0.6 & 2.5 & 0.58 & 0.32 & 0.182 & 4 & 3 & 5 & 1 & GOODE \\
\hline 463 & 2.7 & 2.6 & 0.3 & 1.5 & 0.96 & 0.12 & 0.111 & 1 & 3 & 5 & 1 & GOODE \\
\hline 464 & 2 & 2.2 & 0.6 & 1.5 & 1.1 & 0.27 & 0.3 & 1 & 1 & 5 & 1 & GOODE \\
\hline 465 & 1.9 & 1.4 & 0.4 & 0.7 & 0.74 & 0.29 & 0.211 & 1 & 2 & 5 & 1 & GOODE \\
\hline 466 & 1.4 & 1.4 & 0.2 & 0.5 & 1 & 0.14 & 0.143 & 1 & 4 & 5 & 1 & GOODE \\
\hline 467 & 1.6 & 2.3 & 0.2 & 1 & 1.44 & 0.09 & 0.125 & 3 & 1 & 5 & 1 & GOODE \\
\hline 468 & 1.5 & 2 & 0.4 & 1.1 & 1.33 & 0.2 & 0.267 & 4 & 1 & 5 & 1 & GOODE \\
\hline 469 & 2 & 2.1 & 0.6 & 2.4 & 1.05 & 0.29 & 0.3 & 3 & 3 & 2 & 1 & GOODE \\
\hline 470 & 1.3 & 1.3 & 0.3 & 0.4 & 1 & 0.23 & 0.231 & 2 & 3 & 5 & 1 & GOODE \\
\hline 471 & 1.6 & 1.5 & 0.4 & 0.5 & 0.94 & 0.27 & 0.25 & 1 & 1 & 5 & 1 & GOODE \\
\hline
\end{tabular}




\begin{tabular}{|c|c|c|c|c|c|c|c|c|c|c|c|c|}
\hline 413 & 5.1 & 2.9 & 1 & 12 & 0.57 & 0.33 & 0.188 & . & & 5 & . & ZV83 \\
\hline 414 & 1.8 & 1.6 & 0.7 & 1.7 & 0.87 & 0.42 & 0.365 & . & . & 5 & . & ZV83 \\
\hline 415 & 2.3 & 1.4 & 1.3 & 3.7 & 0.63 & 0.93 & 0.581 & . & . & 5 & . & ZV83 \\
\hline 416 & 2.7 & 2.8 & 0.6 & 5.3 & 1.06 & 0.23 & 0.238 & . & . & 5 & . & ZV83 \\
\hline 417 & 5.9 & 2.2 & 2 & 15 & 0.37 & 0.9 & 0.335 & . & . & 2 & . & ZV83 \\
\hline 418 & 6.2 & 3.5 & 0.9 & 11 & 0.57 & 0.25 & 0.142 & . & . & 5 & . & ZV83 \\
\hline 419 & 3.7 & 3.1 & 0.6 & 6.1 & 0.84 & 0.18 & 0.151 & . & . & 2 & . & ZV83 \\
\hline 420 & 4.4 & 2.5 & 1 & 12 & 0.57 & 0.4 & 0.228 & . & . & 2 & . & ZV83 \\
\hline 421 & 2.7 & 2.2 & 0.6 & 3.1 & 0.83 & 0.25 & 0.211 & . & . & 5 & . & ZV83 \\
\hline 422 & 4.4 & 2.6 & 0.7 & 7.4 & 0.58 & 0.28 & 0.16 & . & . & 5 & . & ZV83 \\
\hline 423 & 5.7 & 4.7 & 1.8 & 52 & 0.82 & 0.39 & 0.317 & . & . & 5 & . & ZV83 \\
\hline 424 & 2.8 & 2.6 & 0.9 & 7.4 & 0.94 & 0.36 & 0.337 & . & . & 2 & . & ZV83 \\
\hline 425 & 3.5 & 2.8 & 0.6 & 3.5 & 0.8 & 0.22 & 0.174 & . & . & 2 & . & ZV83 \\
\hline 426 & 2.4 & 1.4 & 0.4 & 1.7 & 0.59 & 0.3 & 0.178 & . & . & 2 & . & ZV83 \\
\hline 427 & 2.5 & 2 & 0.5 & 4 & 0.8 & 0.27 & 0.211 & . & . & 2 & . & ZV83 \\
\hline 428 & 5.5 & 2.2 & 1 & 11 & 0.41 & 0.42 & 0.173 & . & . & 2 & . & ZV83 \\
\hline 429 & 5 & 3.9 & 1.8 & 31 & 0.78 & 0.46 & 0.36 & . & $\cdot$ & 2 & . & ZV83 \\
\hline 430 & 3.3 & 2.1 & 0.5 & 2.3 & 0.62 & 0.23 & 0.143 & . & . & 5 & . & ZV83 \\
\hline 431 & 2 & 1.5 & 0.5 & 1.3 & 0.77 & 0.29 & 0.225 & . & . & 2 & . & ZV83 \\
\hline 432 & 2.4 & 2.4 & 0.5 & 3.3 & 1.01 & 0.22 & 0.223 & . & . & 5 & . & ZV83 \\
\hline 433 & 2.4 & 1.6 & 0.3 & 1.4 & 0.67 & 0.17 & 0.117 & . & . & 5 & . & ZV83 \\
\hline 434 & 2.9 & 2.9 & 1.1 & 13 & 0.98 & 0.37 & 0.358 & . & . & 2 & . & ZV83 \\
\hline 435 & 4.2 & 3.2 & 0.8 & 13 & 0.75 & 0.26 & 0.198 & . & . & 2 & . & ZV83 \\
\hline 436 & 2.1 & 1.2 & 0.6 & 1.7 & 0.59 & 0.45 & 0.262 & . & . & 5 & . & ZV83 \\
\hline 437 & 3.6 & 2.5 & 1.1 & 6.4 & 0.69 & 0.46 & 0.32 & . & . & 5 & . & ZV83 \\
\hline 438 & 2.5 & 2.2 & 0.6 & 3.1 & 0.89 & 0.25 & 0.223 & . & . & 5 & . & ZV83 \\
\hline 439 & 2.5 & 1.8 & 0.7 & 3 & 0.7 & 0.38 & 0.262 & . & . & 5 & . & ZV83 \\
\hline 440 & 3 & 2.1 & 0.6 & 5.7 & 0.71 & 0.26 & 0.186 & . & . & 5 & . & ZV83 \\
\hline 441 & 2.3 & 1.6 & 0.5 & 3.4 & 0.71 & 0.33 & 0.232 & . & . & 5 & . & ZV83 \\
\hline 442 & 2.3 & 2 & 0.6 & 2.6 & 0.89 & 0.32 & 0.283 & . & . & 5 & . & ZV83 \\
\hline 443 & 3.1 & 2.9 & 0.5 & 2.8 & 0.95 & 0.15 & 0.147 & . & . & 5 & . & ZV83 \\
\hline 444 & 2.8 & 3 & 0.9 & 20 & 1.09 & 0.3 & 0.331 & . & . & 2 & . & ZV83 \\
\hline 445 & 3.8 & 2.7 & 1 & 7.1 & 0.71 & 0.36 & 0.255 & . & . & 5 & . & ZV83 \\
\hline 446 & 2.6 & 0.8 & 0.5 & 1.4 & 0.32 & 0.55 & 0.173 & . & . & 2 & . & ZV83 \\
\hline 447 & 2.3 & 4.2 & 1.6 & 9.3 & 1.83 & 0.38 & 0.696 & 2 & 1 & 5 & 1 & GOODE \\
\hline 448 & 5.3 & 2.4 & 1.1 & 9.1 & 0.45 & 0.46 & 0.208 & 1 & 3 & 2 & 1 & GOODE \\
\hline 449 & 3.9 & 2.1 & 0.5 & 2.4 & 0.54 & 0.24 & 0.128 & 1 & 2 & 5 & 1 & GOODE \\
\hline 450 & 4.3 & 4 & 0.7 & 8 & 0.93 & 0.18 & 0.163 & 4 & 4 & 5 & 1 & GOODE \\
\hline 451 & 4.2 & 4.7 & 0.9 & 12 & 1.12 & 0.19 & 0.214 & 2 & 1 & 5 & 1 & GOODE \\
\hline 452 & 5.1 & 3.7 & 1.1 & 9.6 & 0.73 & 0.3 & 0.216 & 1 & 4 & 5 & 1 & GOODE \\
\hline 453 & 7.1 & 7 & 1.9 & 65 & 0.99 & 0.27 & 0.268 & 2 & 3 & 2 & 1 & GOODE \\
\hline 454 & 5 & 4.8 & 1.2 & 17 & 0.96 & 0.25 & 0.24 & 4 & 1 & 2 & 1 & GOODE \\
\hline 455 & 2.2 & 3.5 & 0.4 & 2.2 & 1.59 & 0.11 & 0.182 & 4 & 3 & 5 & 1 & GOODE \\
\hline 456 & 3.9 & 3.2 & 0.6 & 5.6 & 0.82 & 0.19 & 0.154 & 1 & 1 & 5 & 1 & GOODE \\
\hline 457 & 3.7 & 3 & 0.7 & 6.3 & 0.81 & 0.23 & 0.189 & 4 & 1 & 5 & 1 & GOODE \\
\hline 458 & 2.8 & 3.6 & 0.6 & 3.7 & 1.29 & 0.17 & 0.214 & 3 & 4 & 5 & 1 & GOODE \\
\hline 459 & 2.2 & 3.1 & 0.5 & 3.3 & 1.41 & 0.16 & 0.227 & 3 & 1 & 5 & 1 & GOODE \\
\hline 460 & 2.5 & 2.6 & 0.7 & 3.5 & 1.04 & 0.27 & 0.28 & 4 & 2 & 5 & 1 & GOODE \\
\hline 461 & 5.1 & 1.5 & 0.6 & 3.4 & 0.29 & 0.4 & 0.118 & 1 & 3 & 2 & 1 & GOODE \\
\hline 462 & 3.3 & 1.9 & 0.6 & 2.5 & 0.58 & 0.32 & 0.182 & 4 & 3 & 5 & 1 & GOODE \\
\hline 463 & 2.7 & 2.6 & 0.3 & 1.5 & 0.96 & 0.12 & 0.111 & 1 & 3 & 5 & 1 & GOODE \\
\hline 464 & 2 & 2.2 & 0.6 & 1.5 & 1.1 & 0.27 & 0.3 & 1 & 1 & 5 & 1 & GOODE \\
\hline 465 & 1.9 & 1.4 & 0.4 & 0.7 & 0.74 & 0.29 & 0.211 & 1 & 2 & 5 & 1 & GOODE \\
\hline 466 & 1.4 & 1.4 & 0.2 & 0.5 & 1 & 0.14 & 0.143 & 1 & 4 & 5 & 1 & GOODE \\
\hline 467 & 1.6 & 2.3 & 0.2 & 1 & 1.44 & 0.09 & 0.125 & 3 & 1 & 5 & 1 & GOODE \\
\hline 468 & 1.5 & 2 & 0.4 & 1.1 & 1.33 & 0.2 & 0.267 & 4 & 1 & 5 & 1 & GOODE \\
\hline 469 & 2 & 2.1 & 0.6 & 2.4 & 1.05 & 0.29 & 0.3 & 3 & 3 & 2 & 1 & GOODE \\
\hline 470 & 1.3 & 1.3 & 0.3 & 0.4 & 1 & 0.23 & 0.231 & 2 & 3 & 5 & 1 & GOODE \\
\hline 471 & 1.6 & 1.5 & 0.4 & 0.5 & 0.94 & 0.27 & 0.25 & 1 & 1 & 5 & 1 & GOODE \\
\hline
\end{tabular}




\begin{tabular}{|c|c|c|c|c|c|c|c|c|c|c|c|c|}
\hline 472 & 3.1 & 1.2 & 0.6 & 2.9 & 0.39 & 0.5 & 0.194 & 3 & 3 & 5 & 1 & GOODE \\
\hline 473 & 2.5 & 1.2 & 0.4 & 0.7 & 0.48 & 0.33 & 0.16 & 1 & 3 & 2 & 1 & GOODE \\
\hline 474 & 1.4 & 1.2 & 0.4 & 0.5 & 0.86 & 0.33 & 0.286 & 1 & 2 & 5 & 1 & GOODE \\
\hline 475 & 1.6 & 1.8 & 0.6 & 0.9 & 1.13 & 0.33 & 0.375 & 3 & 2 & 5 & 1 & GOODE \\
\hline 476 & 3 & 0.9 & 0.2 & 0.5 & 0.3 & 0.22 & 0.067 & 1 & 1 & 5 & 1 & GOODE \\
\hline 477 & 1.8 & 2.1 & 0.2 & 0.6 & 1.17 & 0.1 & 0.111 & 1 & 2 & 5 & 1 & GOODE \\
\hline 478 & 3.1 & 3.2 & 0.3 & 2.4 & 1.03 & 0.09 & 0.097 & 2 & 2 & 5 & 1 & GOODE \\
\hline 479 & 3.2 & 1.1 & 0.4 & 0.8 & 0.34 & 0.36 & 0.125 & 1 & 2 & 5 & 1 & GOODE \\
\hline 480 & 1.2 & 1.8 & 0.4 & 0.9 & 1.5 & 0.22 & 0.333 & 1 & 1 & 5 & 1 & GOODE \\
\hline 481 & 2.3 & 2.1 & 0.3 & 1 & 0.91 & 0.14 & 0.13 & 1 & 3 & 5 & 1 & GOODE \\
\hline 482 & 1.9 & 1.3 & 0.2 & 0.4 & 0.68 & 0.15 & 0.105 & 1 & 2 & 5 & 1 & GOODE \\
\hline 483 & 1.3 & 1.7 & 0.4 & 0.5 & 1.31 & 0.24 & 0.308 & 2 & 3 & 5 & 1 & GOODE \\
\hline 484 & 1.9 & 0.9 & 0.3 & 0.5 & 0.47 & 0.33 & 0.158 & 3 & 3 & 5 & 1 & GOODE \\
\hline 485 & 1.5 & 1.3 & 0.2 & 0.3 & 0.87 & 0.15 & 0.133 & 1 & 3 & 5 & 1 & GOODE \\
\hline 486 & 2.4 & 1.9 & 0.2 & 0.7 & 0.79 & 0.11 & 0.083 & 1 & 3 & 5 & 1 & GOODE \\
\hline 487 & 2.2 & 1.5 & 0.5 & 1.1 & 0.68 & 0.33 & 0.227 & 2 & 1 & 5 & 1 & GOODE \\
\hline 488 & 2.1 & 1.5 & 0.4 & 1 & 0.71 & 0.27 & 0.19 & 4 & 1 & 2 & 1 & GOODE \\
\hline 489 & 1 & 2 & 0.4 & 0.3 & 2 & 0.2 & 0.4 & 3 & 3 & 5 & 1 & GOODE \\
\hline 490 & 1.3 & 1.9 & 0.2 & 0.4 & 1.46 & 0.11 & 0.154 & 1 & 4 & 2 & 1 & GOODE \\
\hline 491 & 1.2 & 1.8 & 0.3 & 0.5 & 1.5 & 0.17 & 0.25 & 3 & 1 & 5 & 1 & GOODE \\
\hline 492 & 1.6 & 1.4 & 0.3 & 0.4 & 0.88 & 0.21 & 0.188 & 1 & 3 & 5 & 1 & GOODE \\
\hline 493 & 1.8 & 2.1 & 0.1 & 0.5 & 1.17 & 0.05 & 0.056 & 1 & 3 & 5 & 1 & GOODE \\
\hline 494 & 1.5 & 1.4 & 0.2 & 0.4 & 0.93 & 0.14 & 0.133 & 1 & 3 & 5 & 1 & GOODE \\
\hline 495 & 1.4 & 1.8 & 0.2 & 0.3 & 1.29 & 0.11 & 0.143 & 1 & 3 & 5 & 1 & GOODE \\
\hline 496 & 1 & 1 & 0.2 & 0.2 & 1 & 0.2 & 0.2 & 1 & 3 & 5 & 1 & GOODE \\
\hline 497 & 0.9 & 1.2 & 0.3 & 0.3 & 1.33 & 0.25 & 0.333 & 1 & 3 & 5 & 1 & GOODE \\
\hline 498 & 1.3 & 0.9 & 0.2 & 0.2 & 0.69 & 0.22 & 0.154 & 1 & 1 & 5 & 1 & GOODE \\
\hline 499 & 1.1 & 1.1 & 0.1 & 0.1 & 1 & 0.09 & 0.091 & 1 & 4 & 5 & 1 & GOODE \\
\hline 500 & 1.1 & 0.8 & 0.2 & 0.2 & 0.73 & 0.25 & 0.182 & 3 & 2 & 5 & 1 & GOODE \\
\hline 501 & 2.1 & 1.1 & 0.1 & 0.3 & 0.52 & 0.09 & 0.048 & 1 & 1 & 5 & 1 & GOODE \\
\hline 502 & 1.4 & 0.8 & 0.2 & 0.2 & 0.57 & 0.25 & 0.143 & 1 & 1 & 5 & 1 & GOODE \\
\hline 503 & 1.2 & 1 & 0.2 & 0.2 & 0.83 & 0.2 & 0.167 & 2 & 3 & 5 & 1 & GOODE \\
\hline 504 & 3 & 1.5 & 0.6 & 2.5 & 0.5 & 0.4 & 0.2 & 2 & 3 & 2 & 1 & GOODE \\
\hline 505 & 3.3 & 2 & 0.4 & 1.4 & 0.61 & 0.2 & 0.121 & 1 & 2 & 5 & 1 & GOODE \\
\hline 506 & 2.5 & 1.2 & 0.3 & 0.5 & 0.48 & 0.25 & 0.12 & 3 & 3 & 5 & 1 & GOODE \\
\hline 507 & 1.8 & 2.1 & 0.3 & 0.5 & 1.17 & 0.14 & 0.167 & 1 & 1 & 5 & 1 & GOODE \\
\hline 508 & 1.2 & 2.3 & 0.3 & 0.5 & 1.92 & 0.13 & 0.25 & 3 & 3 & 5 & 1 & GOODE \\
\hline 509 & 1.7 & 2.2 & 0.1 & 0.3 & 1.29 & 0.05 & 0.059 & 1 & 1 & 5 & 1 & GOODE \\
\hline 510 & 0.9 & 1.1 & 0.2 & 0.2 & 1.22 & 0.18 & 0.222 & 3 & 3 & 1 & 1 & GOODE \\
\hline
\end{tabular}




\section{APPENDIX B: BIFACE DATA}

This appendix provides data on bifaces from $41 \mathrm{BX} 901$ recovered during the current project, as well as data collected by C.K. Chandler from the Autrey collection, site 41 BX 903.

\section{KEY TO CODED BIFACE DATA}

$\begin{array}{ll}\text { UNIQUE } & \text { Unique artifact number } \\ \text { SITE } & \text { Site Provenience } \\ \text { LEN } & \text { Maximum Length } \\ \text { WID } & \text { Maximum Width } \\ \text { THK } & \text { Maximum Thickness } \\ \text { WT } & \text { Weight } \\ \text { L/W } & \text { Ratio of Length to Width } \\ \text { T/W } & \text { Ratio of Thickness to Width } \\ \text { TYPE } & \text { Biface Type } \\ \text { ANGLE } & \text { Spine-Plane Angle of Artifact }\end{array}$

TYPE DESCRIPTION

$\begin{array}{ll}\text { B }= & \text { Unspecified Biface } \\ \text { BU }= & \text { Bulverde } \\ \text { CF }= & \text { Clear Fork Gouge } \\ \text { ED }= & \text { Edwards } \\ \text { EDGE }= & \text { Edgewood } \\ \text { EN }= & \text { Ensor } \\ \text { FA }= & \text { Fairland } \\ \text { FR }= & \text { Frio } \\ \text { FRES }= & \text { Fresno } \\ \text { GOW }= & \text { Gower } \\ \text { KIN }= & \text { Kinney } \\ \text { LA }= & \text { Langtry } \\ \text { MARSH }= & \text { Marshall } \\ \text { MONT }= & \text { Montell } \\ \text { NO }= & \text { Nolan } \\ \text { PE }= & \text { Pedernales } \\ \text { PR }= & \text { Unspecified Preform } \\ \text { SC }= & \text { Scallorn } \\ \text { STB }= & \text { Small Thin Biface } \\ \text { TB }= & \text { Thin Biface } \\ \text { TOY = } & \text { Toyah } \\ \text { TRA }= & \text { Travis } \\ \text { YAR }= & \text { Yarbrough } \\ \text { QB }= & \text { Quarry Blank } \\ \text { QBRF }= & \text { Quarry Blank on large Retouched Flake }\end{array}$


UNIQUE SITE LEN WID THK WT L/W T/W TYPE ANGLE

\begin{tabular}{|c|c|c|c|c|c|c|c|}
\hline BX903 & 44 & 23 & 6 & 7 & 1.91 & 0.26 & B \\
\hline BX903 & 58 & 23 & 8.7 & 10 & 2.52 & 0.38 & B \\
\hline BX903 & 92 & 34.5 & 11 & 40 & 2.67 & 0.32 & $B$ \\
\hline BX903 & 45.7 & 29 & 7 & 9.1 & 1.58 & 0.24 & $\mathrm{BU}$ \\
\hline BX903 & 83 & 80 & 16 & 48 & 1.04 & 0.2 & $\mathrm{CF}$ \\
\hline BX903 & . & 20 & 3 & . & . & 0.15 & ED \\
\hline BX903 & . & & 2.6 & . & . & & ED \\
\hline BX903 & . & 16 & 4 & . & . & 0.25 & ED \\
\hline BX903 & . & 21.7 & 4.6 & . & . & 0.21 & $\mathrm{ED}$ \\
\hline BX903 & . & 19 & 3.8 & . & . & 0.2 & $\mathrm{ED}$ \\
\hline BX903 & . & . & 4 & . & . & & $\mathrm{ED}$ \\
\hline BX903 & . & 19 & 4.4 & . & . & 0.23 & ED \\
\hline BX903 & . & & 3.7 & . & . & & $\mathrm{ED}$ \\
\hline BX903 & . & 18 & 3.5 & . & . & 0.19 & $\mathrm{ED}$ \\
\hline BX903 & . & 18 & 4 & . & . & 0.22 & $\mathrm{ED}$ \\
\hline BX903 & . & 15.5 & 4 & . & . & 0.26 & ED \\
\hline BX903 & . & 19.5 & 3 & . & . & 0.15 & $\mathrm{ED}$ \\
\hline BX903 & . & 17 & 3.8 & . & . & 0.22 & ED \\
\hline BX903 & . & . & 3 & 1.1 & . & & $\mathrm{ED}$ \\
\hline BX903 & . & 12 & 3 & 1.2 & . & 0.25 & ED \\
\hline BX903 & 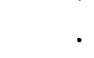 & . & 3 & 1.4 & . & & ED \\
\hline BX903 & 20 & 13 & 3.3 & 1.4 & 1.54 & 0.25 & ED \\
\hline BX903 & . & 16.2 & 3 & 1.5 & . . & 0.19 & $\mathrm{ED}$ \\
\hline BX903 & . & . & 4 & 1.5 & . & - & ED \\
\hline BX903 & . & . & 3.2 & 1.6 & . & . & ED \\
\hline BX903 & . & . & 3.7 & 1.6 & . & . & $\mathrm{ED}$ \\
\hline BX903 & . & & 3.4 & 1.7 & . & . & $\mathrm{ED}$ \\
\hline BX903 & . & 14.5 & 4.2 & 1.8 & . & 0.29 & $\mathrm{ED}$ \\
\hline BX903 & . & 16 & 3.4 & 1.8 & . & 0.21 & ED \\
\hline BX903 & . & 16.5 & 3.6 & 1.8 & . & 0.22 & $\mathrm{ED}$ \\
\hline BX903 & . & & 4.2 & 1.8 & . & . & $\mathrm{ED}$ \\
\hline BX903 & . & . & 3.9 & 1.8 & . & . & ED \\
\hline BX903 & 34 & 15.6 & 4 & 2 & 2.18 & 0.26 & $E D$ \\
\hline BX903 & 31 & 18 & 4 & 2 & 1.72 & 0.22 & $\mathrm{ED}$ \\
\hline BX903 & & . & 3.8 & 2 & 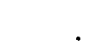 & & $\mathrm{ED}$ \\
\hline BX903 & 31.8 & 18 & 3.8 & 2 & 1.77 & 0.21 & $\mathrm{ED}$ \\
\hline BX903 & & 16.6 & 3 & 2 & . & 0.18 & $\mathrm{ED}$ \\
\hline BX903 & 23 & 15 & 3.5 & 2 & 1.53 & 0.23 & $\mathrm{ED}$ \\
\hline BX903 & & & 3.2 & 2 & & & ED \\
\hline BX903 & 24 & 18 & 4 & 2 & 1.33 & 0.22 & $\mathrm{ED}$ \\
\hline BX903 & 37.2 & 18 & 4 & 2.1 & 2.07 & 0.22 & $\mathrm{ED}$ \\
\hline BX903 & 34 & 19.5 & 4 & 2.1 & 1.74 & 0.21 & $\mathrm{ED}$ \\
\hline BX903 & & 19 & 3.8 & 2.1 & & 0.2 & ED \\
\hline BX903 & 41 & 18 & 3.6 & 2.1 & 2.28 & 0.2 & $\mathrm{ED}$ \\
\hline BX903 & 35.6 & . & 4.3 & 2.1 & -0. & & $\mathrm{ED}$ \\
\hline BX903 & & 14.6 & 4.2 & 2.1 & & 0.29 & $\mathrm{ED}$ \\
\hline BX903 & 30 & 19 & 4.4 & 2.1 & 1.58 & 0.23 & $\mathrm{ED}$ \\
\hline BX903 & 40 & & 3.4 & 2.1 & & & $\mathrm{ED}$ \\
\hline BX903 & 32 & 19.5 & 4 & 2.2 & 1.64 & 0.21 & ED \\
\hline BX903 & . & 18.4 & 4.6 & 2.3 & & 0.25 & $\mathrm{ED}$ \\
\hline BX903 & & 20.4 & 4.5 & 2.3 & & 0.22 & $\mathrm{ED}$ \\
\hline BX903 & 39.5 & 19 & 3.6 & 2.4 & 2.08 & 0.19 & ED \\
\hline BX903 & 36.5 & 16.5 & 4.5 & 2.4 & 2.21 & 0.27 & $E D$ \\
\hline BX903 & 35.6 & 18 & 4 & 2.4 & 1.98 & 0.22 & $\mathrm{ED}$ \\
\hline BX903 & & 18.6 & 3 & 2.7 & & 0.16 & $\overline{E D}$ \\
\hline BX903 & 39 & 18 & 4 & 2.9 & 2.17 & 0.22 & $\mathrm{ED}$ \\
\hline BX903 & & 19 & 3.7 & 3 & & 0.19 & $E D$ \\
\hline
\end{tabular}




\begin{tabular}{|c|c|c|c|c|c|c|c|c|}
\hline 83 & BX903 & 42 & 20.5 & 4.5 & 3 & 2.05 & 0.22 & ED \\
\hline 84 & BX903 & 43 & 20 & 4.5 & 3 & 2.15 & 0.23 & ED \\
\hline 85 & BX903 & 45 & 18 & 4.6 & 3.1 & 2.5 & 0.26 & $\mathrm{ED}$ \\
\hline 86 & BX903 & . & & 4.8 & 3.7 & & & $\mathrm{ED}$ \\
\hline 87 & BX903 & . & 20.6 & 7 & . & . & 0.34 & EDGE \\
\hline 88 & BX903 & . & 32 & 5 & . & . & 0.16 & EDGE \\
\hline 89 & BX903 & . & 22.3 & 6.2 & . & . & 0.28 & EDGE \\
\hline 90 & BX903 & . & & 5 & . & . & . & EDGE \\
\hline 91 & BX903 & 39 & . & 6 & 4.8 & . & . & EDGE \\
\hline 92 & BX903 & 49 & 22 & 6 & 5.5 & 2.23 & 0.27 & EDGE \\
\hline 93 & BX903 & 35 & 28 & 6 & 5.5 & 1.25 & 0.21 & EDGE \\
\hline 94 & BX903 & 43 & 27.7 & 5.4 & 6.5 & 1.55 & 0.19 & EDGE \\
\hline 95 & BX903 & 30 & 20 & 4.5 & 4 & 1.5 & 0.23 & EN \\
\hline 96 & BX903 & 31 & 29.5 & 5 & 4.4 & 1.05 & 0.17 & EN \\
\hline 97 & BX903 & 39.5 & 17.4 & 5.8 & 5 & 2.27 & 0.33 & EN \\
\hline 98 & BX903 & 50 & 20.4 & 5 & 5 & 2.45 & 0.25 & EN \\
\hline 99 & BX903 & 43 & 23.5 & 6 & 6.7 & 1.83 & 0.26 & FA \\
\hline 100 & BX903 & 37.5 & 25 & 6 & 4.8 & 1.5 & 0.24 & FR \\
\hline 101 & BX903 & 46.5 & 20 & 5.6 & 5.3 & 2.33 & 0.28 & FR \\
\hline 102 & BX903 & 39 & 21.4 & 7.6 & 6.8 & 1.82 & 0.36 & FR \\
\hline 103 & BX903 & 55 & 30 & 6 & 8.8 & 1.83 & 0.2 & $\mathrm{FR}$ \\
\hline 104 & BX903 & 50 & 36 & 6 & 10.7 & 1.39 & 0.17 & FR \\
\hline 105 & BX903 & . & 19 & 3 & . & . & 0.16 & FRES \\
\hline 106 & BX903 & . & 21.4 & 4 & . & . & 0.19 & FRES \\
\hline 107 & BX903 & . & 23 & 5.6 & 6.8 & . & 0.24 & FR \\
\hline 108 & BX903 & . & 28 & 5 & 8 & . & 0.18 & FR \\
\hline 109 & BX903 & . & . & 6.4 & 8.3 & . & . & FR \\
\hline 110 & BX903 & . & . & 5.4 & 10 & . & . & FR \\
\hline 111 & BX903 & . & . & 7.5 & 10.3 & . & . & FR \\
\hline 112 & BX903 & . & & 7 & . & . & . & GOW \\
\hline 113 & BX903 & . & 29 & 7.3 & . & 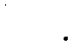 & 0.25 & $\mathrm{KIN}$ \\
\hline 114 & BX903 & 51 & 30 & 6.3 & 7.7 & 1.7 & 0.21 & LA \\
\hline 115 & BX903 & 52 & $v^{\circ}$ & 5 & . & . & . & MARSH \\
\hline 116 & BX903 & . & . & 9 & 13.2 & . & . & MARSH \\
\hline 117 & BX903 & . & . & 5 & 6.7 & . & . & MONT \\
\hline 118 & BX903 & . & 29 & 5 & 8.7 & . & 0.17 & MONT \\
\hline 119 & BX903 & . & . & 5 & 10.2 & . & . & MONT \\
\hline 120 & BX903 & . & & 6.5 & 12.5 & . & . & MONT \\
\hline 121 & BX903 & 53 & 29 & 8 & 15 & 1.83 & 0.28 & NO \\
\hline 122 & BX903 & 90 & 43.5 & 10.5 & 39.3 & 2.07 & 0.24 & PE \\
\hline 123 & BX903 & . & 33.5 & 6 & 8 & . & 0.18 & $\mathrm{PE}$ \\
\hline 124 & BX903 & . & & 7.8 & 8 & . & & $\mathrm{PE}$ \\
\hline 125 & BX903 & 58 & 41 & 10 & 26 & 1.41 & 0.24 & PR \\
\hline 126 & BX903 & 85 & 48 & 12 & 38 & 1.77 & 0.25 & PR \\
\hline 127 & BX903 & 87 & 32 & 15 & 46 & 2.72 & 0.47 & PR \\
\hline 128 & BX903 & 108 & 43 & 23 & 103 & 2.51 & 0.53 & PR \\
\hline 139 & BX903 & 33 & 10 & 2.5 & 1.3 & 3.3 & 0.25 & SC \\
\hline 144 & BX903 & 23 & 13 & 3.8 & 1.7 & 1.77 & 0.29 & $\mathrm{SC}$ \\
\hline 145 & BX903 & 27.6 & 15 & 4.3 & 1.9 & 1.84 & 0.29 & SC \\
\hline 146 & BX903 & 28 & 15.6 & 3.3 & 1.9 & 1.79 & 0.21 & SC \\
\hline 149 & BX903 & 31.4 & 17.7 & 3.5 & 2.2 & 1.77 & 0.2 & SC \\
\hline 150 & BX903 & 38.4 & 15.6 & 3.5 & 2.5 & 2.46 & 0.22 & $\mathrm{SC}$ \\
\hline 151 & BX903 & 32.2 & 21.8 & 5 & 3 & 1.48 & 0.23 & $\mathrm{SC}$ \\
\hline 152 & BX903 & 36.7 & 19.8 & 4.5 & 3 & 1.85 & 0.23 & $\mathrm{SC}$ \\
\hline 153 & BX903 & 38.5 & 17.4 & 4 & 3.1 & 2.21 & 0.23 & $\mathrm{SC}$ \\
\hline 155 & BX903 & 46 & 18.6 & 4.8 & 3.4 & 2.47 & 0.26 & SC \\
\hline 156 & BX903 & 22 & 15.6 & 3.6 & 3.4 & 1.41 & 0.23 & $\mathrm{SC}$ \\
\hline 157 & BX903 & 41.4 & 17.6 & 4.6 & 4 & 2.35 & 0.26 & $\mathrm{SC}$ \\
\hline 158 & BX903 & 46 & 19.4 & 5 & 5 & 2.37 & 0.26 & $\mathrm{SC}$ \\
\hline
\end{tabular}




\begin{tabular}{|c|c|c|c|c|c|c|c|c|}
\hline 159 & BX903 & . & 17.4 & 3.5 & . & . & 0.2 & $\mathrm{SC}$ \\
\hline 160 & BX903 & . & 19 & 3 & . & . & 0.16 & $\mathrm{SC}$ \\
\hline 161 & BX903 & . & & 4 & . & . & 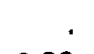 & $\mathrm{SC}$ \\
\hline 162 & BX903 & . & 18.4 & 4 & . & . & 0.22 & $\mathrm{SC}$ \\
\hline 163 & BX903 & . & 19 & 3.5 & . & . & 0.18 & $\mathrm{SC}$ \\
\hline 164 & BX903 & . & 16 & 3.5 & . & . & 0.22 & $\mathrm{SC}$ \\
\hline 165 & BX903 & . & 19 & 2.7 & 1.8 & . & 0.14 & $\mathrm{SC}$ \\
\hline 166 & BX903 & . & 18 & 3.4 & 1.8 & . & 0.19 & $\mathrm{SC}$ \\
\hline 167 & BX903 & . & 17.7 & 4.5 & 1.9 & . & 0.25 & $\mathrm{SC}$ \\
\hline 168 & BX903 & . & & 4.8 & 2.1 & . & . & $\mathrm{SC}$ \\
\hline 169 & BX903 & . & 17.6 & 4 & 2.2 & . & 0.23 & $\mathrm{SC}$ \\
\hline 170 & BX903 & . & 17.5 & 4.3 & 2.3 & . & 0.25 & $\mathrm{SC}$ \\
\hline 171 & BX903 & . & 14.8 & 4.2 & 2.4 & . & 0.28 & $\mathrm{SC}$ \\
\hline 172 & BX903 & . & 20 & 3.5 & 2.4 & . & 0.18 & $\mathrm{SC}$ \\
\hline 173 & BX903 & . & 17 & 4 & 2.4 & . & 0.24 & $\mathrm{SC}$ \\
\hline 174 & BX903 & . & 16.8 & 3.8 & 2.4 & . & 0.23 & $\mathrm{SC}$ \\
\hline 175 & BX903 & . & 13.6 & 4 & 2.5 & . & 0.29 & $\mathrm{SC}$ \\
\hline 176 & BX903 & . & . & 4 & 2.7 & . & & $\mathrm{SC}$ \\
\hline 177 & BX903 & . & 15 & 3.4 & 3.1 & . & 0.23 & $\mathrm{SC}$ \\
\hline 178 & BX903 & : & 20.6 & 4 & 3.1 & . & 0.19 & $\mathrm{SC}$ \\
\hline 179 & BX903 & 58 & & 4 & 3.5 & . & & $\mathrm{SC}$ \\
\hline 180 & BX903 & . & 18.5 & 5.5 & 3.8 & . & 0.3 & $\mathrm{SC}$ \\
\hline 181 & BX903 & . & 21.5 & 4.5 & 4.3 & . & 0.21 & $\mathrm{SC}$ \\
\hline 182 & BX903 & 38 & 21 & 4 & 3.5 & 1.81 & 0.19 & STB \\
\hline 183 & BX903 & 38 & 23 & 4.5 & 3.7 & 1.65 & 0.2 & STB \\
\hline 184 & BX903 & 40 & 21 & 4.3 & 3.8 & 1.9 & 0.2 & STB \\
\hline 185 & BX903 & 41 & 18 & 4.5 & 4.1 & 2.28 & 0.25 & STB \\
\hline 186 & BX903 & 46 & 17 & 5 & 4.4 & 2.71 & 0.29 & STB \\
\hline 187 & BX903 & 39 & 24 & 6.5 & 5 & 1.63 & 0.27 & STB \\
\hline 188 & BX903 & 40 & 21 & 6 & 5.3 & 1.9 & 0.29 & STB \\
\hline 189 & BX903 & 38 & 23 & 7 & 5.4 & 1.65 & 0.3 & STB \\
\hline 190 & BX903 & 48 & 25 & 5.4 & 5.7 & 1.92 & 0.22 & STB \\
\hline 191 & BX903 & 52 & 20 & 5.4 & 5.8 & 2.6 & 0.27 & STB \\
\hline 192 & BX903 & 50 & 18 & 6 & 6 & 2.78 & 0.33 & STB \\
\hline 193 & BX903 & & 25 & 5.1 & 6 & . & 0.2 & STB \\
\hline 194 & BX903 & 46 & 18 & 7 & 6.2 & 2.56 & 0.39 & STB \\
\hline 195 & BX903 & 51 & 23 & 5.7 & 6.4 & 2.22 & 0.25 & STB \\
\hline 196 & BX903 & 44 & 22 & 6 & 6.5 & 2 & 0.27 & STB \\
\hline 197 & BX903 & 40 & 25 & 8 & 7 & 1.6 & 0.32 & STB \\
\hline 198 & BX903 & 62 & 32 & 7 & 7.4 & 1.94 & 0.22 & STB \\
\hline 199 & BX903 & 56 & 21 & 5 & 7.5 & 2.67 & 0.33 & STB \\
\hline 200 & BX903 & 48 & 23 & 10 & 7.8 & 2.09 & 0.43 & STB \\
\hline 201 & BX903 & 48 & 27 & 5.7 & 8.4 & 1.78 & 0.37 & STB \\
\hline 202 & BX903 & 55 & 23 & 7 & 8.7 & 2.39 & 0.3 & STB \\
\hline 203 & BX903 & 65 & 24 & 7 & 10 & 2.71 & 0.29 & STB \\
\hline 204 & BX903 & 48 & 24 & 8 & 10 & 2 & 0.33 & STB \\
\hline 205 & BX903 & 51 & 30 & 8 & 11.3 & 1.7 & 0.27 & STB \\
\hline 206 & BX903 & 54 & 25 & 8 & 11.3 & 2.16 & 0.32 & STB \\
\hline 207 & BX903 & 51 & 29 & 7 & 11.4 & 1.76 & 0.28 & STB \\
\hline 208 & BX903 & 58 & 29 & 7.8 & 11.8 & 2 & 0.24 & STB \\
\hline 209 & BX903 & 47 & 32 & 6.7 & 12.4 & 1.47 & 0.24 & STB \\
\hline 210 & BX903 & 47 & 30 & 7.2 & 13 & 1.57 & 0.22 & STB \\
\hline 211 & BX903 & 47 & 27 & 8.7 & 13 & 1.74 & 0.27 & STB \\
\hline 212 & BX903 & 56 & 27 & 8.5 & 14.5 & 2.07 & 0.31 & STB \\
\hline 213 & BX903 & 64 & 30 & 7 & 15 & 2.13 & 0.23 & STB \\
\hline 214 & BX903 & 54 & 27 & 8.6 & 15.1 & 2 & 0.26 & STB \\
\hline 215 & BX903 & 54 & 28 & 8.8 & 15.1 & 1.93 & 0.31 & STB \\
\hline 216 & BX903 & 87 & 22 & 7.4 & 15.3 & 3.95 & 0.4 & STB \\
\hline 217 & BX903 & 57 & 32 & 7.3 & 16.2 & 1.78 & 0.23 & STB \\
\hline
\end{tabular}




\begin{tabular}{|c|c|c|c|c|c|c|c|c|c|}
\hline 218 & BX903 & 59 & 32 & 9.8 & 17 & 1.84 & 0.23 & STB & 34 \\
\hline 219 & BX903 & 69 & 30 & 9.7 & 19 & 2.3 & 0.33 & STB & 26 \\
\hline 220 & BX903 & 69 & 28 & 10.4 & 20 & 2.46 & 0.35 & STB & 34 \\
\hline 221 & BX903 & 65 & 27 & 9.3 & 20.4 & 2.41 & 0.39 & STB & 47 \\
\hline 222 & BX903 & & 38 & 8 & 22.1 & . & 0.21 & STB & 26 \\
\hline 223 & BX903 & 64 & 32 & 10 & 23.9 & 2 & 0.31 & STB & 32 \\
\hline 224 & BX903 & 68 & 30 & 10 & 24.4 & 2.27 & 0.33 & STB & 41 \\
\hline 225 & BX903 & 60 & 37 & 9 & 25.6 & 1.62 & 0.24 & STB & 28 \\
\hline 226 & BX903 & 72 & 36 & 10 & 25.7 & 2 & 0.28 & STB & 28 \\
\hline 227 & BX903 & 67 & 37 & 11.2 & 27.5 & 1.81 & 0.3 & STB & 31 \\
\hline 228 & BX903 & 68 & 41 & 10.3 & 32.3 & 1.66 & 0.25 & STB & 28 \\
\hline 229 & BX903 & 82 & 39 & 11 & 32.7 & 2.1 & 0.28 & STB & 29 \\
\hline 230 & BX903 & 76 & 45 & 10.7 & 39.7 & 1.69 & 0.24 & STB & 28 \\
\hline 231 & BX903 & 70 & 41 & 13.6 & 41.6 & 1.71 & 0.33 & STB & 32 \\
\hline 232 & BX903 & " & 31 & 6.5 & . & . & 0.21 & TB & \\
\hline 233 & BX903 & . & 38.2 & 7 & . & . & 0.18 & $\mathrm{~TB}$ & ${ }^{\circ}$ \\
\hline 234 & BX903 & 65 & 32 & 6 & 13.9 & 2.03 & 0.19 & TB & . \\
\hline 235 & BX903 & 70 & 42 & 6 & 15 & 1.67 & 0.14 & TB & ${ }^{\circ}$ \\
\hline 236 & BX903 & 91 & 40 & 3.5 & 15 & 2.28 & 0.09 & TB & \\
\hline 237 & BX903 & 93 & 36 & 8 & 15.7 & 2.58 & 0.22 & TB & . \\
\hline 238 & BX903 & 86 & 30 & 6 & 15.8 & 2.87 & 0.2 & $\mathrm{~TB}$ & . \\
\hline 239 & BX903 & 70 & 32 & 7 & 18 & 2.19 & 0.22 & TB & . \\
\hline 240 & BX903 & 63 & 31 & 10 & 21 & 2.03 & 0.32 & TB & . \\
\hline 241 & BX903 & 71 & 45 & 7 & 24.8 & 1.58 & 0.16 & TB & . \\
\hline 242 & BX903 & 103 & 43 & 11.7 & 55.3 & 2.4 & 0.27 & TB & . \\
\hline 243 & BX903 & 68 & . & 5 & 4.3 & . & & TOY & . \\
\hline 244 & BX903 & 56 & 20 & 9.6 & 11 & 2.8 & 0.48 & TRA & . \\
\hline 245 & BX903 & & 24 & 8.6 & 15.4 & . & 0.36 & TRA & . \\
\hline 246 & BX903 & 50.2 & 25 & 8 & 10.5 & 2.01 & 0.32 & TRA & . \\
\hline 247 & BX903 & & 21.6 & 9.6 & 17 & & 0.44 & TRA & . \\
\hline 248 & BX903 & 80 & 26 & 10 & 18.4 & 3.08 & 0.38 & TRA & . \\
\hline 249 & BX903 & 88 & 29 & 11 & 25.3 & 3.03 & 0.38 & TRA & . \\
\hline 250 & BX903 & 84 & 21.2 & 6 & 9 & 3.96 & 0.28 & YAR & . \\
\hline 251 & BX903 & $\cdot$ & 17.4 & 3.8 & . & . & 0.22 & B & . \\
\hline 252 & BX903 & 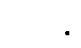 & 22.6 & 4 & . & . & 0.18 & B & . \\
\hline 253 & BX903 & 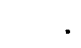 & 22 & 3.8 & . & . & 0.17 & B & . \\
\hline 254 & BX903 & 53 & 15 & 4.4 & 4 & 3.53 & 0.29 & B & . \\
\hline 255 & BX903 & 36 & 17 & 8 & 5.1 & 2.12 & 0.47 & B & . \\
\hline 256 & BX903 & 51 & 19.5 & 7 & 7.8 & 2.62 & 0.36 & B & . \\
\hline 257 & BX903 & 56 & 25 & 7.5 & 11.7 & 2.24 & 0.3 & B & . \\
\hline 258 & BX903 & 53.7 & 26 & 9 & 12.3 & 2.07 & 0.35 & B & . \\
\hline 259 & BX903 & 52 & 25 & 8 & 14 & 2.08 & 0.32 & B & . \\
\hline 260 & BX903 & 70 & 19 & 11 & 14 & 3.68 & 0.58 & B & 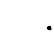 \\
\hline 261 & BX903 & 56.5 & 30 & 10 & 18 & 1.88 & 0.33 & B & \\
\hline 262 & BX901 & 122 & 71 & 39 & 315 & 1.72 & 0.55 & QB & 47 \\
\hline 263 & BX901 & 140 & 103 & 33 & 550 & 1.36 & 0.32 & QB & 45 \\
\hline 264 & BX901 & 130 & 48 & 38 & 261 & 2.71 & 0.79 & $\mathrm{QB}$ & 59 \\
\hline 265 & BX901 & 117 & 84 & 24 & 277 & 1.39 & 0.29 & QB & 41 \\
\hline 266 & BX901 & 92 & 71 & 28 & 135 & 1.3 & 0.39 & QB & 35 \\
\hline 267 & BX901 & 96 & 70 & 29 & 182 & 1.37 & 0.41 & $\mathrm{QB}$ & 42 \\
\hline 268 & BX901 & 98.5 & 70 & 21 & 147 & 1.41 & 0.3 & QB & 35 \\
\hline 269 & BX901 & 101 & 83.5 & 27 & 240 & 1.21 & 0.32 & $\mathrm{QBRF}$ & 41 \\
\hline 270 & BX901 & 147 & 78 & 35 & 410 & 1.88 & 0.45 & QBRF & 46 \\
\hline 271 & BX901 & 86 & 45 & 22 & 89 & 1.91 & 0.49 & QBRF & 45 \\
\hline 272 & BX901 & 59 & 44 & 15 & 41 & 1.34 & 0.34 & QB & 33 \\
\hline 273 & BX901 & 77 & 55.5 & 22 & 85 & 1.39 & 0.4 & QB & 47 \\
\hline 274 & BX901 & 72.5 & 48 & 17.5 & 69 & 1.51 & 0.36 & PR & 45 \\
\hline 275 & BX901 & 74 & 39.5 & 17 & 53.9 & 1.87 & 0.43 & PR & 37 \\
\hline 276 & BX901 & 112 & 73 & 25.5 & 234 & 1.53 & 0.35 & QBRF & 52 \\
\hline
\end{tabular}




$\begin{array}{llrllrrlll}277 & \text { BX901 } & 88 & 52 & 20 & 100 & 1.69 & 0.38 & \text { QBRF } & 42 \\ 278 & \text { BX901 } & 135 & 96 & 37 & 485 & 1.41 & 0.39 & \text { QB } & 49 \\ 279 & \text { BX901 } & 118 & 56 & 29 & 191 & 2.11 & 0.52 & \text { PR } & 45 \\ 280 & \text { BX901 } & 77 & 48 & 16 & 69 & 1.6 & 0.33 & \text { PR } & 41 \\ 281 & \text { BX901 } & 120 & 73 & 39 & 315 & 1.64 & 0.53 & \text { QB } & 50 \\ 282 & \text { BX901 } & 113 & 83 & 26 & 277 & 1.36 & 0.31 & \text { QB } & 44\end{array}$



